Universidade de São Paulo

FACULDADE DE EDUCAÇÃo

Gisela Maria do VAL

\title{
A CHAMADA DA EDUCAÇÃO: \\ SOBRE A GOVERNAMENTALIZAÇÃO PEDAGÓGICA NOS TEXTOS JORNALÍSTICOS
}




\section{Gisela MaRia do VAL}

\section{A CHAMAdA DA EDUCAÇÃO: \\ SOBRE A GOVERNAMENTALIZAÇÃO PEDAGÓGICA NOS \\ TEXTOS JORNALÍSTICOS}

Dissertação apresentada à Faculdade de Educação da Universidade de São Paulo para obtenção do título de Mestre em Educação.

Área de concentração: Psicologia e Educação

Orientador: Prof. Dr. Julio Groppa Aquino 
AUTORIZO A REPRODUÇÃO E DIVULGAÇÃO TOTAL OU PARCIAL DESTE TRABALHO, POR QUALQUER MEIO CONVENCIONAL OU ELETRÔNICO, PARA FINS DE ESTUDO E PESQUISA, DESDE QUE CITADA A FONTE.

Catalogação na Publicação

Serviço de Biblioteca e Documentação

Faculdade de Educação da Universidade de São Paulo

$37.017 \quad$ Val, Gisela Maria do

V135c A chamada da educação: sobre a governamentalização pedagógica nos textos jornalísticos / Gisela Maria do Val; orientação Julio Groppa Aquino. São Paulo: s.n., 2011.

$128 \mathrm{p}$.

Dissertação (Mestrado - Programa de Pós-Graduação em Educação. Área de Concentração: Psicologia e Educação) - - Faculdade de Educação da Universidade de São Paulo.

1. Foucault, Michel, 1926-1984 2. Discurso 3. Educação escolar 4. Governamentalidade 5. Jornalismo impresso I. Aquino, Julio Groppa, orient. 
Nome: Val, Gisela Maria do

Título: A chamada da educação: sobre a governamentalização pedagógica nos textos jornalísticos

Dissertação apresentada à Faculdade de Educação da Universidade de São Paulo para obtenção do título de Mestre em Educação.

Aprovado em:

Banca Examinadora

Prof. Dr. Instituição:

Julgamento: Assinatura:

Prof. Dr. Instituição:

Julgamento: Assinatura:

Prof. Dr. Instituição: Julgamento: Assinatura: 


\section{AgradeCimentos}

Há equivalência entre ser e viver, entre sentir-se existir e sentir-se viver. [...] Nessa sensação de existir insiste uma outra sensação humana, que tem a forma de um com-sentir a existência do amigo. A amizade é a instância desse com-sentimento da existência do amigo no sentimento da existência própria. Mas isso significa que a amizade tem um estatuto ontológico e, ao mesmo tempo, político. A sensação de ser é, de fato, já sempre divida e com-divida, e a amizade nomeia essa condivisão. Não há aqui nenhuma intersubjetividade - esta quimera dos modernos -, nenhuma relação entre sujeitos: em vez disso o ser mesmo é dividido, é não-identico a si, o eu e o amigo são as duas faces - ou os dois polos - dessa com-divisão. [...] $O$ amigo não é um outro eu, mas uma alteridade imanente da "mesmidade", um tornar-se outro do mesmo. No ponto em que eu percebo a minha existência como doce, a minha sensação é atravessada por um com-sentir que desloca e deporta para o amigo, para o outro mesmo. A amizade é essa des-subjetivação no coração mesmo da sensação mais íntima de si.

Giorgio Agamben

Foi na estância do com-sentimento que as linhas desta dissertação foram produzidas. Sem as pessoas que me acompanharam, este trabalho jamais teria sido concretizado, de modo que o uso da primeira pessoa do plural em meu texto não é mera formalidade acadêmica. Assim, os agradecimentos aqui manifestos são tímidos perante a grandeza das relações que se forjaram ao longo deste tempo, relações estas que muito me ultrapassam e que me apresentaram uma forma de vida que se tornou por demais valiosa para mim.

Agradeço à minha família - ao meu pai Amaro, à minha mãe Gisella, às minhas irmãs Maria Augusta e Maria Isabel e aos meus sobrinhos João Amaro e José Gabriel pela imensurável compreensão durante os extensos períodos de afastamento, mesmo em momentos delicados. A condescendência com minhas ausências foi primordial para que, nas fases de concentração e escrita, eu pudesse dedicar-me integralmente à pesquisa.

A colaboração e o acolhimento de minhas amigas e parceiras de trabalho foram vitais para minha fase acadêmica que aqui se encerra. Agradeço, em especial, à Erica, à Kiki, à Marilda e à Regina, pela compreensão, pelas folgas, pelas conversas e por todo o apoio.

Minha trajetória na Faculdade de Educação da Universidade de São Paulo foi sempre entremeada de companhias fundamentais. Na graduação em Pedagogia, algumas amigas tornaram-se ímpares e a elas estas linhas de agradecimento são insuficientes. À Christiane agradeço pelas imprescindíveis indicações e informações, pelo eterno incentivo e por ter acreditado em mim mesmo quando eu mesma duvidava. À Ana Clara, pela companhia acolhedora, pelo apoio nos momentos de desânimo e pela confiança nas ações diante das quais minha certeza era titubeante. À Eliane, pelas conversas infindáveis, pela paciência em ouvir minhas dificuldades acadêmicas e pelo insuperável bom humor. À Crislei, pela presença marcante e contínua, por todos os momentos de aflição e dúvida compartilhados, pelo apoio e pelo encorajamento quando 
os prazos e as avaliações eram curtos e cruéis, pelos dias e noites em finais de semana e feriados em que a escrita e a leitura seriam nossas únicas companheiras se não fosse nossa igual perseverança; sou grata, enfim, por tê-la tido ao meu lado durante todo este belo tempo. A todas, agradeço pelas ocasiões descontraídas e pelos encontros de amizade sem os quais a vida perderia, e muito, sua graça.

Agradeço sobremaneira aos funcionários da faculdade por toda gentileza, atenção, presteza e boa vontade, qualidades que tornaram tanto minha graduação, como meu mestrado, bem mais fáceis e agradáveis.

Os professores que me acompanharam nesta fase mostram-se indispensáveis para que meu percurso fosse atravessado por uma indescritível alegria de ler, estudar e pensar. A eles manifesto minha gratidão, em especial, àqueles que estiverem presentes por mais tempo e de maneira mais próxima. Ao professor Jorge Ramos do Ó, sou grata pela infinita paciência de ouvir, de ensinar e de conduzir. Suas contribuições foram por demais preciosas e sua companhia, um presente valioso das terras d'além-mar. À banca de qualificação - professoras Cyntia Regina Ribeiro e Sônia Aparecida Moreira França - agradeço pelas sugestões de grande valia ao meu trabalho. Suas observações direcionaram meus estudos e foram fundamentais para meus escritos.

O percurso dos pós-graduandos é sempre narrado como solitário e infausto. Tal profecia não se concretizou no meu caso, e isso se deu principalmente por minha participação em um grupo de estudos e de orientação que em muito ultrapassa a significação da palavra grupo. Mais do que um conjunto de pessoas dispostas de modo a formar um todo, nosso grupo é intenso, dinâmico e portador de um cuidado com o outro que oferece apoio e sustentação aos seus membros. Agradeço, assim, a todos que dele participam ou participaram desde minha entrada, sejam aqueles que me ajudaram na fase exploratória do trabalho - Daniel, Lua, Carlos Manuel, Thomas, Adélia, Cláudia, Carlos Rubens -, sejam aqueles que chegaram depois de escolhas terem sido feitas e rumos terem sido tomados - André, Flavio, Guilherme, Gustavo, Lou e Silas.

Ainda dentre os integrantes desse grupo, manifesto gratidão especial aos que compartilharam intensamente do projeto e da execução de minha pesquisa, constituindo-se como presenças marcantes na difícil arte de pensar e escrever. Ao Fabio, ao Danilo e ao Marcelo agradeço pelo auxílio nos períodos conturbados e nos de calmaria, pelas brilhantes manifestações de pensamento e pelas doces palavras que ladearam meu caminhar, tornando-o mais iluminado e prazeroso. À Daniela, por sua companhia incondicional, seja nos longos períodos de estudo, seja nos momentos de descontração. Sua alegria e seu bom humor, além de suas importantes contribuições às minhas ideias, tornaram minha vida e meus escritos muito mais ricos. À Elisa, amiga adorável e sempre disposta, agradeço pela escuta, pela leitura e pela reescrita. Seu apoio, sua presença e sua amizade tornaram-na uma presença indispensável nos tempos mais difíceis e nos mais suaves; sua alegria e seus conselhos bruniram e suavizaram o penoso período final de minha escrita. A essa quase coautora ofereço minha imensa gratidão por, mesmo tão jovem, mostrar-me caminhos que não percebia, ideias às quais me rendi e erros que aos montes cometi. 
Por fim, nestas ligeiras palavras, dedico especial gratidão ao meu orientador, na tentativa - provavelmente sem sucesso - de expressar em um gesto o reconhecimento de sua insigne presença como norteador não só deste trabalho, mas de todo um modo de vida fundado na força do pensamento como âmago, e na amizade como parceira. A presença de Julio Groppa Aquino em meu percurso acadêmico ensinou-me, de maneira definitiva, o significado da palavra professor. Agradeço por seus numerosos cuidados, por suas argutas avaliações, por sua infindável paciência e por sua atenção desmedida. Tê-lo encontrado foi uma obra do acaso que se transformou em um acontecimento em minha vida. Presenciar sua atitude combativa e compartilhar de sua presença e de suas inquietações foi mais do que um privilégio. Ao lado dele, descobri a beleza de ir aonde quer que seja, buscando o novo com os mesmos velhos sonhos e, ao cabo destes, encontrando nem unanimidade, nem recompensa, nem consenso - tudo se desfazendo novamente para um eterno novo começo. 


\section{RESUMO}

VAL, Gisela Maria do. A chamada da educação: sobre a governamentalização pedagógica nos textos jornalísticos. 2011. 128f. Dissertação (Mestrado) - Faculdade de Educação, Universidade de São Paulo, São Paulo, 2011.

Na presente dissertação, efetuamos uma reflexão sobre textos jornalísticos dedicados ao tema da educação escolar. O objetivo do trabalho foi problematizar as racionalidades e práticas ali constituídas, as quais compõem materialidades que concebem e levam a cabo um projeto político específico para a sociedade contemporânea. Para tanto, analisamos as matérias veiculadas sobre educação escolar no jornal Folha de São Paulo entre 1996 e 2006, tomando como referência o campo teórico dos estudos pósestruturalistas e, em especial, o legado analítico de Michel Foucault. Consideramos que, por meio dos textos jornalísticos, são produzidos enunciados que sustentam um discurso afiliado às perspectivas econômicas, políticas, sociais e culturais predominantes. Assim, nosso estudo pretendeu apontar as relações de poder que ali se processam, analisando-as como práticas cotidianas e capilares que são incorporadas por esse discurso; compreendemos tais práticas sem qualquer conotação repressora ou autoritária, mas como fomentadoras de políticas de verdade que circulam em espaços públicos, interagindo produtivamente com seus leitores e reverberando na instituição escolar. Ao tomar como objeto de pesquisa o discurso jornalístico sobre a educação, nosso trabalho centrou-se na investigação do modo como as matérias jornalísticas operam via produção, articulação e circulação das relações de saber-poder na contemporaneidade pedagógica. O rol de textos selecionados e examinados perfaz uma teia discursiva que, por um lado, justifica e atualiza a importância da educação escolar e, por outro, intervém nas supostas dificuldades enfrentadas pela escola para continuar operando nos tempos e espaços em que tradicionalmente tem operado. Quando abordam a educação, os textos jornalísticos não estão veiculando apenas informações, opiniões e comentários sobre ela, mas compõem enunciados que problematizam e prescrevem formas de fazer, de aprender, de ensinar e, sobretudo, de ser e de compreender o mundo, arregimentando assim uma eficaz maquinaria de governamentalização pedagógica.

Palavras-chave: Discurso jornalístico. Educação escolar. Governamentalização. Michel Foucault. Folha de São Paulo. 


\begin{abstract}
Val, Gisela Maria do. The call for education: on the pedagogical governmentalization in journalistic texts. 2011. 128f. Dissertação (Mestrado) - Faculdade de Educação, Universidade de São Paulo, São Paulo, 2011.

This dissertation focuses on journalistic texts which address the issue of school education. Its reflection aimed at problematizing the rationalities and practices built therein, which make up materialities that conceive and unfold a specific political project for the contemporary society. For that purpose, articles on school education published in the newspaper Folha de São Paulo between 1996 and 2006 were analyzed, based on the theoretical field of the poststructuralist studies, with special emphasis on the legacy of Michel Foucault. It is assumed that, through journalistic texts, enouncements are produced that maintain a discourse associated with the predominant economic, political, social and cultural perspectives. Thus, this study looked to point out the power relations which take place therein, analyzing them as everyday and capillary practices which are incorporated by this discourse. Such practices are seen without any repressive or authoritarian connotation, but rather as a means to foster truth policies which circulate in public spaces, interacting productively with their readers and reverberating in the school institution. By having the journalistic discourse on education as its object, this study focused on the investigation of the manner in which journalistic articles operate via production, articulation and circulation of knowledge-power relations in contemporary education. The array of texts selected and examined makes up a discursive web which, on the one hand, justifies and updates the importance of school education, and, on the other hand, intervenes in the alleged difficulties faced by school to continue operating in the spaces and times where it has traditionally operated. When they approach education, journalistic texts are not conveying only information, opinions and comments about it, but are composing enouncements that problematize and prescribe ways of acting, learning, teaching and, above all, being and understanding the world, thus assembling an effective machinery of pedagogical governmentalization.
\end{abstract}

Key-words: Journalistic discourse. School education. Governmentalization. Michel Foucault. Folha de São Paulo. 


\section{SUMÁRIO}

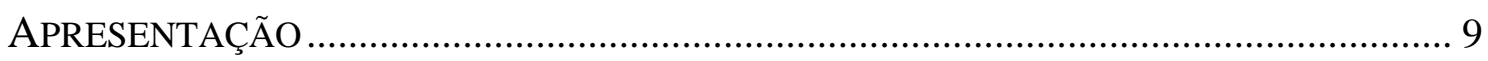

I - INTERLOCUÇÕES TEMÁTICAS E METODOLÓGICAS:

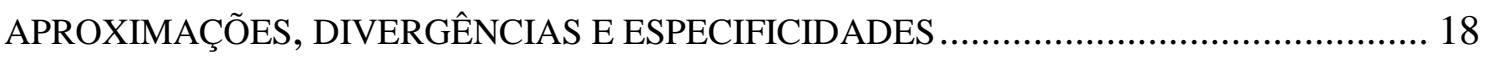

1.1 - As produções acadêmicas sobre a educação escolar na mídia ........................... 18

1.2 - Metodologia da pesquisa: locus, recorte temporal e seleção do material........... 25

II - O PRIMADO DA INFORMAÇÃO:

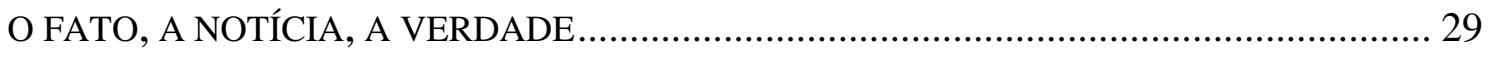

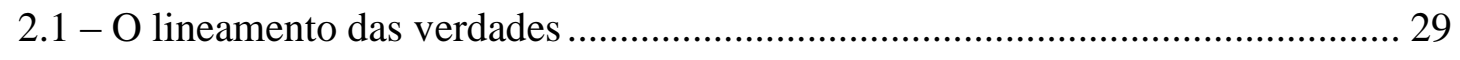

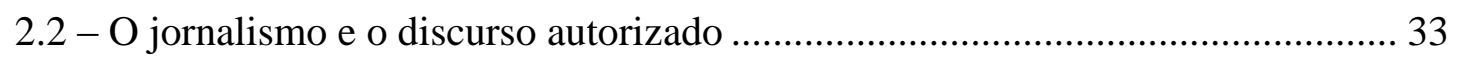

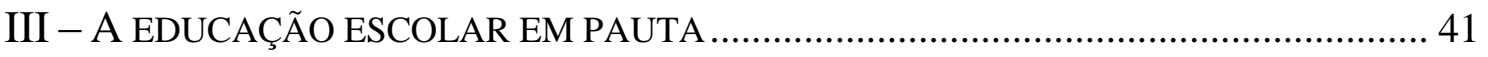

3.1 - Um briefing panorâmico............................................................................... 42

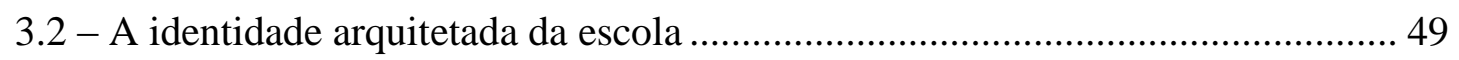

3.2.1 Uma instituição indispensável ............................................................. 53

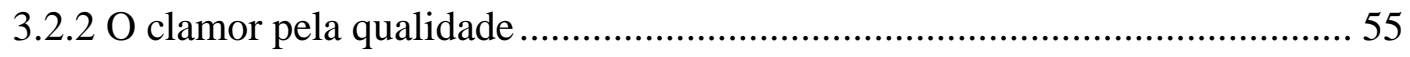

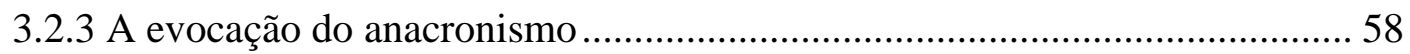

3.3 - O receituário da salvação escolar ................................................................. 61

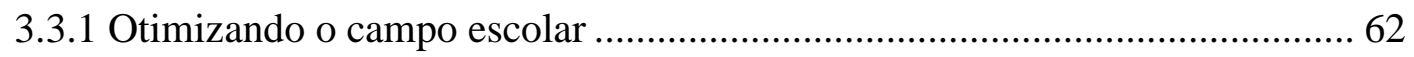

3.3.2 Comunidade e escola: uma integração almejada ....................................... 69

IV - FECHAMENTO DA EDIÇÃO:

OS DESDOBRAMENTOS DO DISCURSO JORNALÍSTICO SOBRE EDUCAÇÃO ................ 73

4.1 - O discurso do jornal e o governo dos viventes ................................................. 73

4.2 - O processo de governamentalização: educação do corpo e da alma.................... 81

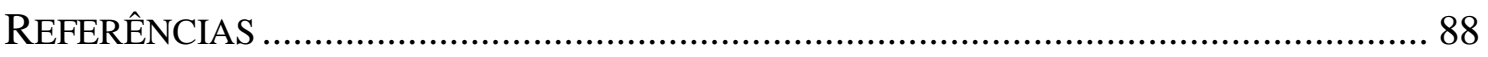

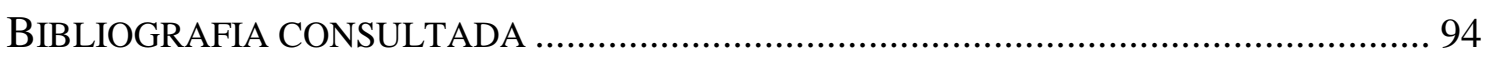

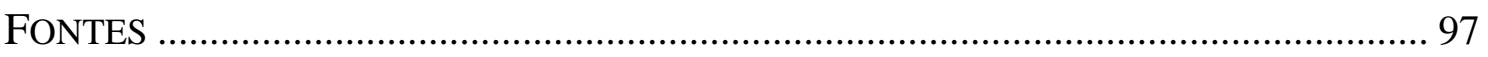




\section{APRESENTAÇÃO}

[...] apregoa-se a ameaça do monstruoso para reforçar essa ideologia do bem e do mal, do permitido e do proibido, que o ensino de hoje não ousa transmitir com tanta segurança quanto outrora. [...] hoje, os jornalistas são incentivados, convidados, compelidos a dizê-lo com mais força e mais insistência do que os professores o podem fazer. Vou lhe contar uma história. ${ }^{1}$

Michel Foucault

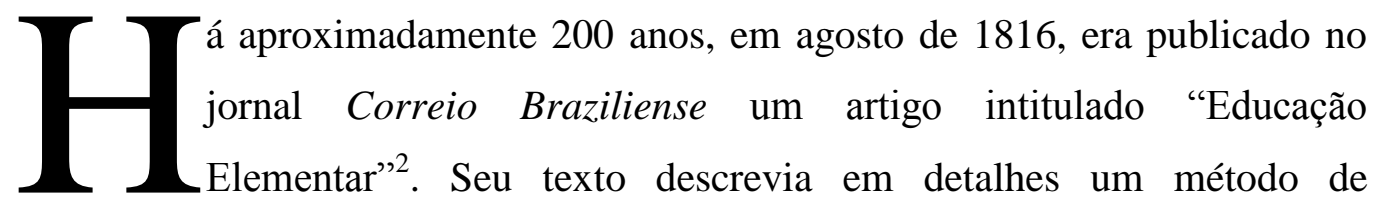
alfabetização, prescrevendo passo a passo como deveria ser o ensino das sílabas e a progressão dos meninos.

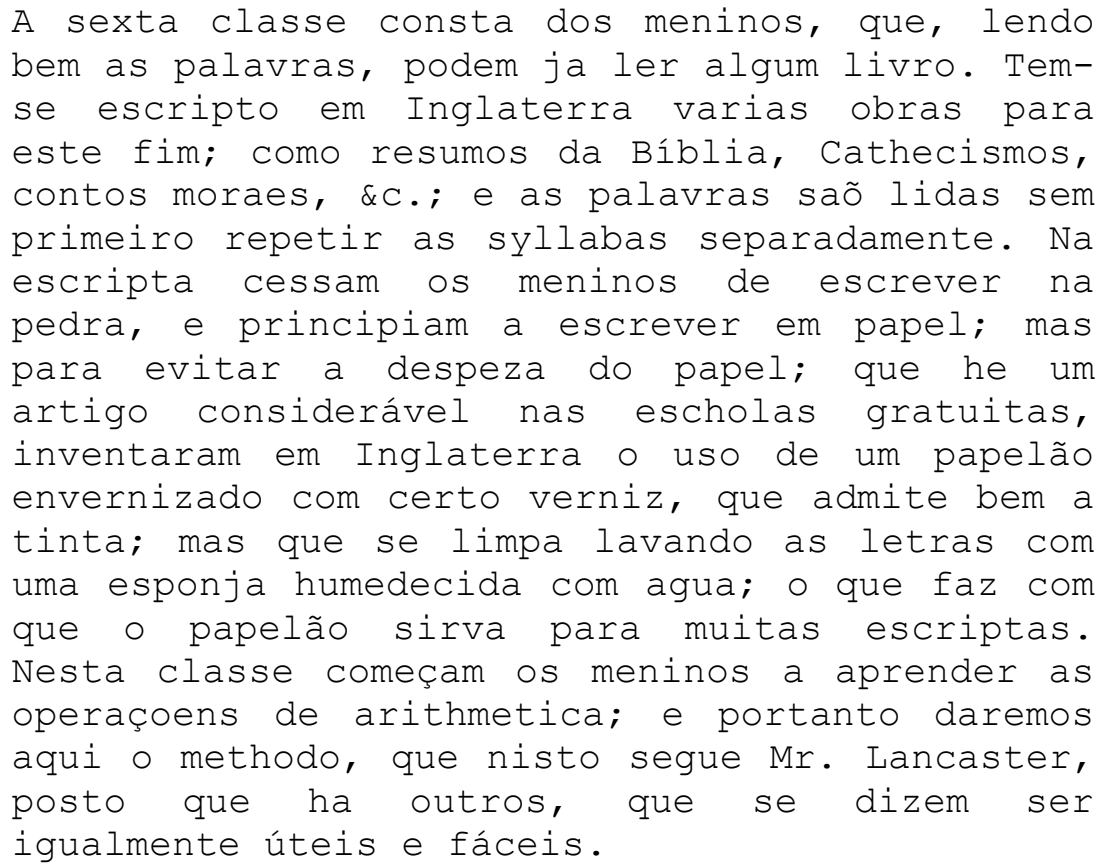

${ }^{1}$ [...] on brandit la menace du monstrueux pour renforcer cette idéologie du bien et du mal, du permis et du défendu que l'enseignement d'aujourd'hui n'ose pas transmettre avec autant d'assurance qu'autrefois. [...] aujourd'hui, les journalistes sont poussés, invités, contraints à le dire d'autant plus fort et avec d'autant plus d'insistance que les professeurs ne peuvent plus le dire. Je vais vous raconter une histoire. (FOUCAULT, Michel. Par-delà le bien et le mal. In : Dits et écrits II. Paris: Gallimard, p.230, tradução nossa.)

2 Autor desconhecido. Correio Braziliense, n.099, Miscelânea, p.205-209. Londres: W. Lewis, Paternoster, ago. 1816. 
Em janeiro de 1911, o jornal O Estado de São Paulo publicou o artigo "Notas Pedagogicas", , em que é tecida uma severa crítica ao programa de construção de escolas normais e à desordem que então reinava no projeto de formação de professores para o ensino primário.

As providencias isoladas, sem nexo nenhum,
desligadas de um plano de conjunto; as
providencias tomadas a esmo, sem estudo e
ponderação; as providencias que se encaixam á
ultima hora na formidavel cauda dos orçamentos
- constituem a causa principal da lastimavel
desordem, da vergonha anarchia que se nota em
nossa disparatada organisação escolar. Por isso
é que esta não passa de uma colcha de retalhos
de disposições encongruentes, cujo fim
pedagógico ninguem conseguiria explicar em
outro paiz que não fosse a Analphabetolandia,
famosa na historia e na legenda. [...] A escola da
capital resente-se de enormes defeitos. Seu
valor é quasi nullo, seu programa nada
satisfactorio, seu regimen interno prejudicial,
como já temos salientado muitas vezes, em
confrontos com outras nações.

Já em nossos dias, a Folha de São Paulo publicou em janeiro de 2011, no caderno Mercado, um artigo ${ }^{4}$ de opinião assinado por um economista que trata da estruturação do currículo como um importante fator para a melhoria do desempenho dos alunos nas avaliações. Ele sugere a utilização de métodos estruturados de ensino elaborados por organizações públicas ou privadas.

Uma pesquisa da Fundação Lemann também
encontrou um efeito positivo de métodos
estruturados de ensino no desempenho dos alunos
de escolas públicas municipais de são Paulo. Em
resumo, a adoção de currículos claros e
material didático estruturado tem o potencial
de elevar a qualidade da educaça no Brasil.
Para que seu efeito seja maximizado, ela deve
ser integrada com o sistema de avaliação e
programas de formação inicial e continuada de
professores.

\footnotetext{
${ }^{3}$ Autor desconhecido. O Estado de São Paulo, n.11715, p.2. São Paulo, 10 jan. 1911.

${ }^{4}$ VELOSO, Fernando. A importância do currículo. Folha de São Paulo, Mercado, 08 jan. 2011. Disponível em: http://www1.folha.uol.com.br/fsp/mercado/me0801201129.htm. Acessado em: 25 jan. 2011.
} 
Métodos pedagógicos, formação de professores, currículos. O que se constata nesses três excertos é que a educação escolar tem sido um tema para as falas jornalísticas desde a época em que o jornal era impresso na Inglaterra, chegava de navio a um Brasil colonial, e tinha circulação mensal. Há quase 200 anos os temas são similares e compõem um discurso que se repete com uma regularidade assombrosa.

O jornalismo observa os acontecimentos, produzindo relatos que constituem o que ali é apresentado, ou seja, há um deslocamento do imaterial do acontecimento para uma identidade, uma concretude singular no interior de uma formação controlada e perpetuada.

O discurso é sempre dispersão, constituído que é por elementos que não estão ligados por nenhum princípio a priori. $\mathrm{O}$ que fornece a uniformidade do discurso jornalístico é seu entrelaçamento entre "os objetos, os tipos de enunciação, os conceitos, as escolhas temáticas", todos englobados em uma "regularidade (uma ordem, correlações, posições e funcionamentos, transformações)" (FoUCAULT, 2007b, p.43). Tem-se assim uma formação discursiva por meio da qual o jornalismo opera, produzindo o objeto sobre o qual fala, delimitando o dizível e limitando o que é permitido dizer.

O jornalismo lida com a atualidade, o que lhe proporciona aderência. Ao trabalhar com matérias jornalísticas, movemo-nos no agora, com racionalidades produzidas há algum tempo ou mesmo recém-constituídas, mas operando dia a dia, página a página, edição a edição.

Talvez, esse jogo entre discurso, subjetivação e verdade tenha sido um dos fatores que levaram Michel Foucault - referência capital de nosso trabalho - a aceitar o convite do diário italiano Corriere della Sera para que fosse ao Irã escrever artigos sobre sua visão diante do que se passava naquele país. A exploração de um acontecimento do presente poderia pôr em questão, para além do jornalismo, sua própria concepção de poder. Seu interesse residia, sobretudo, no jogo que barra, interdita e invalida o discurso das massas (ERIBON, 1990), mas o papel da mídia na transmissão de ideias também o inquietava. Didier Eribon, que conviveu com Foucault naquela época, lembra que "ele se questionava muito sobre o papel dos jornais na circulação das ideias e principalmente sobre a confusão generalizada dos valores" (p.273). 
Questionamento semelhante a esse foi o que as matérias diárias sobre a educação escolar nos suscitaram: o que desperta tanto interesse sobre tal assunto? O trabalho de investigação levou-nos ao desafio de trabalhar com o presente, na companhia de um pensador que pretendia, em sua incursão pelo jornalismo, "assistir ao nascimento das ideias e à explosão de sua força” (FouCAULT, 2008b, p.50). O que almejamos, contudo, é bem mais modesto: traçar um perfil dos ditos e escritos produzidos sobre a escola em uma época e um local específicos, mapeando as tensões, as racionalidades e as verdades materializadas e tentando compreender seus efeitos. Nos termos de Foucault, "a preocupação de dizer o que se passa [...] [é afetada] pelo desejo de adivinhar o que se esconde sob essa palavra precisa, flutuante, misteriosa, absolutamente simples: 'Hoje"” (2010b, p.279-280). Adentremos a questão, remontando ao cenário educacional que se delineava há duas décadas.

Em 5 de março de 1990, na cidade tailandesa de Jomtien, realizou-se a Conferência Mundial sobre Educação para Todos, organizada pela Organização das Nações Unidas para a Educação, a Ciência e a Cultura (UNESCO), pelo Fundo das Nações Unidas para a Infância (UNICEF), pelo Programa das Nações Unidas para o Desenvolvimento (PNDU) e pelo Banco Mundial. Naquele mesmo ano, foi publicada uma declaração que evoca o direito de toda pessoa à educação, reforçando um artigo da Declaração Universal dos Direitos Humanos. Ela baseia-se na proposição de que a educação pode "contribuir para conquistar um mundo mais seguro, mais sadio, mais próspero e ambientalmente mais puro, que, ao mesmo tempo, favoreça o progresso social, econômico e cultural, a tolerância e a cooperação internacional" (UNESCO, 1990). O Brasil foi um dos países signatários que tomou os objetivos da declaração como base para seu Plano Nacional de Educação; disso decorre um compromisso moral com os princípios defendidos pelo documento, os quais, em síntese, tratam de assegurar educação com qualidade para todas as crianças até 2015 e de expandir as oportunidades de aprendizagem para jovens e adultos.

Assim como essa conferência, outros encontros ocorreram na década de 1990 com o objetivo de estabelecer metas para o aprimoramento e a otimização da educação escolar, principalmente nos países em desenvolvimento. Entre eles, destacamos: a Conferência de Cúpula de Nova Delhi (1993), para a qual os nove países em desenvolvimento mais populosos foram convidados a expor seus planos, pois juntos abrigavam um importante percentual da população mundial e apresentavam a mais 
baixa produtividade do sistema educacional; e o Relatório da Comissão Internacional sobre Educação para o Século XXI (1996), no qual foram apresentados novos conceitos para a educação, tais como aprender a conhecer, aprender a fazer, aprender a viver com os outros e aprender a ser, conceitos estes eleitos como seus quatro pilares fundamentais (UNESCO, 2003).

Vários textos foram produzidos e muitos dos enunciados ali proferidos abalizaram as políticas educacionais brasileiras nos anos 90 . O foco principal do movimento era a melhoria da educação, principalmente a básica e pública; para tanto, era necessário superar grandes desafios da área: diminuir o número de analfabetos e analfabetos funcionais; universalizar o atendimento na educação infantil e na educação básica; e extinguir a repetência e a evasão, conforme artigo assinado pelo deputado federal Ivan Valente na Folha de São Paulo, em 7 de maio de 1998.

O tema educação de qualidade passou a ser, a partir de então, muito mais citado, apresentando-se como uma das principais proposições tanto dos discursos reformadores, como dos continuístas. Iniciou-se uma época que pode ser classificada como mais uma dentre as dedicadas ao aprimoramento da educação - e, consequentemente, da instituição escolar -, herdeira de outras tantas reformas educacionais.

Seguindo a tendência internacional, em 1993 foi publicado no Brasil o Plano Decenal de Educação para Todos, documento elaborado pelo Ministério da Educação. Seu texto marca a aceitação pelo governo brasileiro das teses e estratégias implantadas pela Declaração Mundial sobre Educação para Todos, articulando respostas às demandas educacionais definidas pelos organismos internacionais. Ele resultou num acordo nacional baseado em três eixos: atuação em conjunto das esferas federal, estadual e municipal; elaboração dos parâmetros curriculares; e incremento do salário dos professores (BRASIL, 1993).

Em dezembro de 1996 foi promulgada a Lei de Diretrizes e Bases da Educação Brasileira (LDB - Lei 9394/96), a qual, “inspirada nos princípios de liberdade e nos ideais de solidariedade humana, tem por finalidade o pleno desenvolvimento do educando, seu preparo para o exercício da cidadania e sua qualificação para o trabalho" (BRASIL, 1996).

Apenas com essa pequena mostra de materiais é possível visualizar uma teia discursiva enredada em torno da ação educativa; nela, discursos operam para validar 
proposições que são transmitidas e reforçadas. Além dos documentos oficiais, há também as produções acadêmicas e os meios de comunicação, fazendo circular enunciados e produzindo novas argumentações, as quais definem um modelo específico de educação como sendo o ideal e apontam sua falta como um grande revés econômico, social, político e ético.

Nessa época, o tema educação passou a ser bem mais citado nos meios de comunicação, especialmente nos jornais de circulação diária. Em pesquisa realizada no arquivo on-line do jornal Folha de São Paulo, constatamos que, em 1994, foram publicados 727 artigos em que a educação compunha o tema e a ideia defendida pelo texto; já em 1997, a marca chegou a 3350, evidenciando um aumento de aproximadamente $460 \%$. A diferença, bastante significativa para um intervalo de apenas três anos, indica que o interesse pelas novas disposições educacionais era uma das pautas jornalísticas mais importantes ao final da década de 1990.

Os textos produzidos nesse período oferecem proposições que podem, à primeira vista, parecer prosaicas, mas que comportam jogos de contraposição entre o verdadeiro e o falso, incitações e modos de entender a educação e a escola de forma bem específica. Vê-se aí como o discurso, mobilizado por sua instância de enunciação, opera para criar efeitos veridictórios.

O jornalismo é uma atividade que se pauta pelo dizer verdadeiro, independentemente do veículo, do gênero de discurso que adota ou do público a que se destina. Pressupõe-se que, ao apresentar a notícia, o relato reproduza o episódio autêntico, apresentando uma descrição relacionada ao acontecimento real. De forma mais ou menos explícita, a proposição de legitimidade na descrição dos fatos está sempre presente na notícia.

Tal legitimidade não apenas reverbera nos leitores do jornal, mas, em conjunto com outros discursos, compõe todo um cenário, constituindo uma verdade que se naturaliza sobre a educação. Como uma película aderente, essa verdade apresenta-se de tal forma que se torna muito difícil enxergar ou imaginar outras maneiras de educar, outros modos de funcionamento para a instituição escolar.

Em nossa pesquisa, mapeamos os discursos sobre educação que o jornal Folha de São Paulo apresentou no período de 1996 a 2006, investigando qual modelo de educação vigora nas narrativas e quais prescrições são ali oferecidas, ou seja, quais são 
as verdades apresentadas e que efeitos poderiam suscitar. A hipótese deste trabalho é a de que os discursos jornalísticos que anunciam, examinam e prescrevem a educação escolar são práticas que se constituem como parte de uma arte de administração e supervisão das condições de vida dos cidadãos como um todo.

A configuração de uma análise centrada nos aspectos do discurso, da verdade e do governo ancorou-se nas ideias de Michel Foucault sobre as relações de poder e suas tramas com o saber, os processos de subjetivação, os jogos de verdade e os regimes de enunciação. Tal arcabouço teórico ajudou-nos a delimitar zonas de inteligibilidade constituídas por táticas e estratégias de uma forma de governo

[...] caracterizada pela heterogeneidade de autoridades e agências, empregando igualmente uma desmesurada variedade de técnicas e formas de conhecimento cientifico destinadas a avaliar e a melhorar a riqueza, a saúde, a educação os costumes e os hábitos da população (Ó, 2003, p.5).

No delineamento de nosso objeto, questionamo-nos se não seria já esperado que a educação escolar fosse um assunto intensamente divulgado na imprensa, e o porquê de nosso estranhamento com a quantidade de matérias a esse respeito. Tal inquietação deve-se a várias razões, as quais remetem a uma questão principal: os dizeres sobre a escola apresentados pelo jornal estão inseridos em um discurso que segue determinada ordem. Não lemos, falamos e repetimos informações quaisquer. O que se publica sobre a escola não são coisas fortuitas; aí operam relações de poder que atuam, tornam-se naturalizadas e estão presentes tanto no discurso mais explicitamente normatizador, quanto naqueles que apresentam um caráter supostamente libertário.

O objetivo de nosso trabalho não foi fazer uma crítica aos posicionamentos políticos da imprensa, nem se tratou de uma tentativa de desautorizar seu discurso. Antes, a partir de certo estranhamento em relação à naturalização de ideias e valores aí em uso, investigamos as falas apresentadas como elementos discursivos que circulam, interagindo produtivamente não apenas com os leitores. Além disso, discutimos qual produtividade é aspirada e que tipo de educação é narrada.

Circundando esses temas - sujeito (educação), discurso (regimes de verdade) e governamento -, nossa intenção foi problematizar os enunciados apresentados sobre educação escolar a fim de analisar que tipos de sujeito e de sociedade são prescritos e convocados. 
Os textos abordados são sempre entremeados de outros textos, e destecer essas tramas é como caminhar por um terreno instável. Problemas surgem como depressões em um chão quase fluido. $\mathrm{O}$ encontro com algumas materialidades levou-nos a interrogações como: será que o tipo de educação almejado por essas práticas discursivas e a espécie de sujeito constituído por elas são o relevo de determinadas técnicas de controle? O discurso midiático sobre educação escolar compõe uma regulação dos fundamentos e práticas escolares? Refletir sobre essas questões no âmbito das ideias de Foucault faz-nos pensar contra aquilo que conhecemos e no que por algum tempo acreditamos; nosso esforço, pois, foi desnaturalizar questões simples e cotidianas, narradas e descritas em páginas diárias das folhas de um jornal.

Entendendo que a produção de sujeitos também se dá na trama desses relatos e dos repertórios que eles ajudam a construir, tomamos os enunciados da mídia como parte de uma tecnologia ativa e operante, capaz de ensinar e fazer circular informações consonantes e dissonantes, operando, assim, um fictício jogo de liberdades discursivas, as quais engrossam o caldo das argumentações e legitimam os discursos como livres e democráticos.

Assim, pretendemos apresentar neste trabalho uma nanogenealogia do presente, identificando de que forma o tema escolar configurou-se em uma década de consolidação de um discurso sobre uma educação democrática, plural e redentora. Nosso interesse voltou-se àqueles discursos em que a educação aparece como fulcro para a constituição de um sujeito específico; nesse campo, propusemo-nos a analisar os enunciados apresentados pela imprensa de forma a levar suas especificidades em consideração, e a enfrentá-los como acontecimentos.

Para problematizar os enunciados das matérias jornalísticas, examinamos brevemente, no primeiro capítulo, as produções acadêmicas que abordaram a convergência entre mídia e educação, além de artigos sobre o tema publicados em periódicos da área educacional. O objetivo de tal estudo bibliográfico foi conhecer as ideias e propostas de pesquisas já empreendidas, enfatizando os aspectos em que elas se aproximavam ou divergiam de nossa abordagem. A partir daí, tentamos estabelecer com tais pesquisas um diálogo que, de algum modo, fosse fecundo para este trabalho. Em seguida, apresentamos nossa metodologia de trabalho, explicitando como foi feita a escolha do locus e do recorte temporal, bem como a seleção do material. 
Iniciamos o segundo capítulo tratando do tema da verdade à luz do pensamento de Nietzsche e de Foucault, autores que refutaram o caráter metafísico ou transcendente da verdade e afirmaram seu aspecto fundamentalmente histórico. A partir de seus argumentos, é possível dizer que a verdade não existe sem o poder, ou fora dele, mas é seu efeito e repousa no berço dos saberes. Na segunda parte desse capítulo, discorremos mais detidamente sobre a imbricação entre poder, saber e verdade, ressaltando suas reverberações no jornalismo - um meio de comunicação de massa capaz de produzir sentidos e de sedimentar repertórios cognitivos. Analisamos a imprensa como um dos fios que tecem uma extensa rede em que enunciados são produzidos, circulam, legitimam-se e acabam por parecerem naturais aos leitores, aos sujeitos narrados e à instituição descrita.

No terceiro capítulo, por meio de um mapeamento dos escritos jornalísticos selecionados, bem como de seus desvios e convergências, começamos a delinear a fisionomia das verdades presentes nos artigos. Também nos dedicamos a analisar os ditos e escritos sobre educação: como ela é narrada, quem são seus personagens, quais são as paisagens descritas.

A última parte do trabalho apresenta os desdobramentos do discurso sobre educação veiculados pela mídia impressa diária. Concluímos com uma argumentação sobre o vínculo entre as práticas discursivas jornalísticas, a produção da verdade e o governo da alma e do corpo dos homens. 


\section{I - INTERLOCUÇÕES TEMÁTICAS E METODOLÓGICAS: APROXIMAÇÕES, DIVERGÊNCIAS E ESPECIFICIDADES}

Paul Veyne, em seu livro sobre Michel Foucault, narra uma conversa com o pensador francês em que este questiona: "o que faz com que a verdade seja tão pouco verdadeira?" (2009, p.45-46). Essa indagação resume exemplarmente as inquietações que motivaram esta pesquisa. O que tentamos discernir é o modo como certo conceito torna-se realidade, quais são as modulações e intensidades que os discursos adquirem conforme o tempo a que pertencem, e quais são as práticas que eles geram. Tais questionamentos também habitaram os interesses de outros pesquisadores. Conhecer as ideias que povoam a rede discursiva das produções acadêmicas é fundamental para sabermos o que foi escrito, quais são as proposições apresentadas e como nosso pensamento relaciona-se com esses trabalhos. Pensar acompanhado, seja para se opor ou para anuir, é sempre mais profícuo.

\section{1 - As produções acadêmicas sobre a educação escolar na mídia}

Mapeando uma amostra da produção acadêmica sobre as conexões entre mídia e educação, investigamos os aspectos e dimensões que vêm sendo destacados em algumas dissertações de mestrado, teses de doutorado e publicações em periódicos. Nessa breve revisão da literatura acadêmica, foi possível verificar que são diversas as caracterizações da mídia como propagadora de temáticas escolares, como mediadora de conhecimentos ou como instrumento pedagógico. Também há a defesa de uma educação voltada para a construção de uma postura crítica e criteriosa em relação à mídia.

O principal meio midiático eleito como objeto da maioria das pesquisas de mestrado e doutorado aqui aludidas é a televisão, seguido pela Tecnologia de Informação e Comunicação (TIC) ${ }^{5}$ e pelas publicações impressas (revistas e jornais).

Uma parte significativa dos textos encontrados elege a mídia como aliada instrumental na construção do conhecimento, considerando os aspectos educacionais e

\footnotetext{
${ }^{5}$ Conjunto de recursos tecnológicos que facilitam o trânsito de informações, agilizando, horizontalizando e tornando o conteúdo mais virtual por meio da digitalização e da comunicação em redes. Seu grande diferencial é a interatividade, ou seja, a participação ativa do usuário e a capacidade de manipulação do conteúdo da informação. Esses recursos proporcionam a automação e/ou a comunicação de vários tipos de processos existentes nos negócios, no ensino e na pesquisa científica, na área bancária e financeira etc.
} 
informacionais, bem como as possibilidades de transformação das práticas educativas. Os trabalhos procuram, nesse sentido, analisar e investigar as práticas midiáticas no âmbito da educação. Entre as produções mais recentes nessa linha, podemos citar, entre outros, as seguintes dissertações: Quitungo, mídia e cidadania: a política de "mídia e educação" da prefeitura do Rio de Janeiro em uma perspectiva discursiva $e$ comunitária, de Carlos André Cantisani Maranhão (2007); A recepção das mensagens televisivas e a construção do sentido: uma experiência, de Margaret Presser (2007); e Oficina de TV, uma prática educomunicativa: estudo de caso de uma criança abrigada, de Helenita Sommerhalder-Miike (2008).

Tais trabalhos também convocam a discussão sobre a inclusão curricular de conteúdos e formatos midiáticos. Entre as principais argumentações que fundamentam os textos, encontra-se a proposição de que o saber que circula na escola é chancelado por informações de veículos de informação prestigiados, de acordo com um processo em que os artigos e reportagens são utilizados como uma espécie de ponte que vincula os conteúdos escolares ao cotidiano, à realidade, criando assim significações para o conhecimento escolar.

Encontramos também pesquisas que priorizam o discurso da mídia e analisam de que forma os postulados de identidades processam-se no interior dos enunciados, como são transmitidos aos leitores, quais construções de significados e valores são propostas e de que maneira os indivíduos relacionam-se com esses enunciados, fixando ou recusando formas e modos identitários. Como exemplo, temos as teses Escola e escola on-line: alguns efeitos do discurso pedagógico midiatizado, de Ana Silvia Couto de Abreu (2006); A representação infantil da violência na mídia: uma perspectiva para repensar a educação, de Marcia Aparecida Giuzi Mareuse (2007); A educação infantil representada: uma análise da revista Nova Escola, de Cleriston Izidro dos Anjos (2008).

Algumas pesquisas que se dedicaram a investigar o discurso sobre educação circunscrevem-se a analisar periódicos educacionais especializados destinados ao público acadêmico. Essas pesquisas utilizam os impressos educacionais como um corpus documental. Entre elas, temos a dissertação de Edivania Pinheiro Ferreira Cancian (2008), intitulada $O$ discurso de uma revista especializada em educação: um olhar sobre a construção metafórica do professor e a dissertação de Fernanda 
Romanezi da Silveira (2006), intitulada Um estudo das capas da Revista Nova Escola: 1986-2004.

As investigações que pretenderam analisar as publicações de grande circulação concentram-se nas revistas semanais. Nesses trabalhos, o enfoque é centrado na mídia impressa como objeto de pesquisa. As análises convergem para as representações que a educação adquire nas narrativas e para quais são as imagens produzidas e reproduzidas por esses meios de comunicação. Um dos exemplos é a dissertação de mestrado de Ana Paula Fonseca (2008), A construção da educação na revista Veja, em que a autora faz uma análise sobre as imagens da educação representadas nas capas da revista; há também a tese de doutorado A escola na mídia: nada fora do controle, de Cristianne Maria Famer Rocha (2005), que analisou as reportagens publicadas nas revistas Veja e Istoé sobre violência escolar, novas tecnologias de comunicação e informação, e educação à distância, com o propósito de compreender as condições que permitem que a instituição escolar modernize-se para continuar produzindo corpos e mentes dóceis, disciplinados, educados e controlados; e A mídia como dispositivo da governamentalidade neoliberal: os discursos sobre educação nas revistas Veja, Época e Istoé, tese de doutorado de Vera Regina Serezer Gerzson, (2007), que empreendeu um estudo que aponta como estratégias das relações de poder neoliberais utilizam as práticas incorporadas no discurso das mídias como verdades que circulam nos espaços públicos. Seguindo a linha de análise das imagens midiáticas sobre a escola, Geraldo Sabino Ricardo Filho (2005) produziu a dissertação A boa escola do discurso da mídia, em que apresenta as considerações sobre educação na revista Veja, elaborando um estudo sobre a representação midiática do conceito de boa escola.

Focalizando a pesquisa em jornais, encontramos o trabalho de Marcos Luiz Cripa (2008), A cobertura da educação no jornal Folha de São Paulo. Nessa dissertação, o autor delineia, em um estudo comparativo, a cobertura do jornal sobre o tema em 1973 e 2002.

Os periódicos acadêmicos são importantes instâncias de pesquisa para uma caracterização da superfície das publicações sobre mídia e educação. Entre as revistas pesquisadas, encontramos uma vasta bibliografia que segue uma divisão temática semelhante à das teses e dissertações.

No decorrer da pesquisa, deparamo-nos com um rol de textos dedicados exclusivamente ao tema da mídia. No volume 26 do periódico Educar em revista 
(julho/dezembro de 2005), foi publicado um dossiê sobre o tema Mídia e educação: a produção de novos sujeitos e novas pedagogias, com onze artigos que enfatizam o cinema, a televisão, as revistas, a propaganda, a internet, a educação e o professor em um mundo em constante comunicação e transformação. Dentre os textos, destacamos Mídia e educação: em cena, modos de existência jovem, de Rosa Maria Bueno Fischer, que aborda a televisão como instrumento fundamental da sociedade do espetáculo ${ }^{6}$, operando na nomeação e na construção de uma normalidade juvenil; e Dispositivo da maternidade: mídia e a produção pedagógica de sujeitos, práticas e normas, em que Fabiana de Amorim Marcello faz uma análise de como o dispositivo da maternidade é construído e atualizado, e de que modo ele opera nos enunciados das revistas Veja, Caras e Crescer.

Outra publicação que destinou um espaço diferenciado às imbricações entre mídia e educação foi a revista Educação \& Sociedade, volume 29, de 2008, oferecendo onze artigos que se dedicam mais especificamente à análise sobre a incorporação das tecnologias de comunicação e informação na educação, debatendo seu uso pedagógico.

Também Maria da Graça Setton, em seu texto A mídia e o ensino superior: é possível a criação de um consenso?, analisou as matérias sobre ensino universitário veiculadas pelos jornais O Estado de São Paulo, Jornal da Tarde e Folha de São Paulo, tecendo considerações sobre o processo de produção das mensagens midiáticas e sua difusão nos meios de comunicação de massa. Seu trabalho foi publicado na revista Educação \& Sociedade em 2002, no volume 27.

Examinando a utilização da imprensa na sala de aula e sua presença nos livros didáticos, o artigo Mídia, escola e leitura crítica do mundo, de Graça Caldas, veiculado em 2006 na revista Educação e Sociedade, volume 27, oferece-nos uma proposta de educação para uma leitura crítica da mídia.

Na Universidade Federal do Rio Grande do Sul há duas pesquisadoras que se dedicaram ao estudo dos meios de comunicação: Marisa Vorraber Costa e Rosa Maria Bueno Fischer. Tendo Michel Foucault como referencial teórico, suas investigações são voltadas para a análise das mídias como produtoras de identidades, com ênfase nas questões de regulação por meio dos discursos que atuam nos processos de subjetivação.

\footnotetext{
${ }^{6}$ Conceito desenvolvido por Guy Debord no livro de mesmo nome, em que se discute a influência da mídia na sociedade como um processo que leva o homem à passividade e à aceitação dos valores preestabelecidos pelo capitalismo.
} 
Entre as produções de Rosa Maria Bueno Fischer, podemos destacar sua tese de doutorado Adolescência em discurso: mídia e produção de subjetividade, de 1996, que trata dos discursos da mídia sobre a adolescência, partindo da constatação de que meninos e meninas adolescentes adquirem modelos de identidade principalmente nos textos e imagens dos meios de comunicação. Também de sua autoria são: $O$ estatuto pedagógico da mídia: questões de análise, texto publicado em 1997 no periódico Educação \& Realidade; Foucault e a análise do discurso em educação, artigo publicado no periódico Cadernos de Pesquisa, em 2001; Problematizações sobre o exercício de ver: mídia e pesquisa em educação, artigo publicado em 2002b pela Revista Brasileira de Educação; O dispositivo pedagógico da mídia: modos de educar na (e pela) TV, texto publicado na revista Educação e Pesquisa, em 2002a; Mídia e juventude: experiências do público e do privado na cultura, veiculado no Caderno Cedes, em 2005b; e Mídia, máquinas e práticas pedagógicas, publicado na Revista Brasileira de Educação, em 2007. Os trabalhos Fischer perseveram no tema da moldagem e da fixação das identidades por processos de subjetivação produzidos pela cultura da imagem por meio dos discursos midiáticos, especialmente aqueles transmitidos pela televisão.

Já entre as produções de Marisa Vorraber Costa (2000, 2002) sobre essa mesma temática, há trabalhos tais como: Estudos culturais em educação: mídia, arquitetura, brinquedo, biologia, literatura, cinema..., um estudo publicado em 2000 sobre as relações entre a mídia e a fabricação de identidades sociais, com foco sobre a produção da revista Nova Escola; e um texto publicado na Revista Brasileira de Educação em 2002, intitulado Ensinando a dividir o mundo: as perversas lições de um programa de televisão, que expõe a mídia, particularmente a televisão, como um dispositivo que integra o aparato pedagógico das sociedades governamentais modernas, sendo responsável por ensinar muitas coisas à população, entre elas, um conjunto de verdades que compõem o currículo cultural no qual se aprende a dividir o mundo.

As pesquisas dessas autoras conduzem-se por uma direção de pensamento em que o discurso midiático é analisado como uma das estratégias de subjetivação dos sujeitos. Seguindo a mesma linha, temos o texto $O$ discurso dos experts na constituição das identidades infantis e de gênero na mídia impressa brasileira, publicado em 2005 na revista Pro-posições, no qual Claudia Amaral dos Santos analisa os discursos que governam as condutas maternas; Marlucy Alves Paraíso, com Currículo e mídia: a 
produção de um discurso para e sobre a escola, publicado na revista Educação e Pesquisa, em 2001; e Fabiana de Amorim Marcello, com o trabalho O conceito de dispositivo em Foucault: mídia e produção agonística de sujeitos-maternos, publicado na revista Educação e Realidade, em 2004.

As propostas da maioria das produções acadêmicas aqui citadas apresentam uma distância considerável das articulações deste trabalho. De modo geral, as pesquisas que não possuem referencial foucaultiano analisam o discurso das mídias como fonte de estatutos identitários e de formas opressoras de subjetivação. Segundo elas, haveria uma espécie de discurso imposto e receptores passivos que aceitam e incorporam as diretrizes transmitidas.

Nosso pensamento percorre um caminho pavimentado por ideias que diferem daquela que aponta o discurso dominante como responsável por subjugar e dominar os sujeitos. Partimos da hipótese de que a relação com a mídia dá-se mais na forma de práticas de subjetivação do que de sujeição; de construções menos forjadas em representações, e mais em técnicas de $\mathrm{si}^{7}$; de exercício mais de uma liberdade regulada do que de dominação.

As pesquisas com a mesma abordagem teórica que a nossa descrevem o jogo engendrado entre mídia e processos de subjetivação. Algumas delas apresentam uma análise que culpabiliza a mídia, argumento que, a nosso ver, não pode ser utilizado como fator primordial nos meandros dessas relações de constituição do sujeito. Responsabilizar a mídia neoliberal por um processo de fixação e transformações de identidades é imaginar que seria possível existir outra mídia que estabelecesse relações neutras. Sobre essa questão, consideramos que os meios de comunicação de massa fazem parte de uma requintada teia de discursos e técnicas que compõe dispositivos de poder nos quais se processa a conexão de práticas sociais de dominação apoiadas em técnicas discursivas. Tais forças agem sobre o sujeito, que as processa por meio de uma relação consigo na constituição dessa experiência.

Um trabalho aproxima-se do nosso locus de pesquisa. Na dissertação de Marcos Luiz Cripa é realizado um estudo comparativo sobre a cobertura jornalística da educação no jornal Folha de São Paulo entre os anos 1973 e 2002. Seu texto sustenta

\footnotetext{
7 “[...] procedimentos que, sem dúvida, existem em toda civilização, pressupostos ou prescritos aos indivíduos para fixar sua identidade, mantê-la ou transformá-la em função de determinados fins, e isso graças a relações de domínio de si sobre si ou de conhecimentos de si por si” (FOUCAULT, 1997, p.109).
} 
que a presença do tema teve seu espaço reduzido, principalmente depois do projeto de modernização do jornal ${ }^{8}$. Em suas considerações, o autor assevera que, apesar de, em editoriais, a educação ser apontada como principal saída para a solução dos problemas sociais brasileiros, essa preocupação não se reflete nas reportagens que retratam o dia a dia. Para ele, os espaços destinados ao tema, a falta de uma editoria específica - o fim da editoria ocorreu com a modernização do jornal - e a concentração de fontes ligadas à elite educacional fizeram com que a educação tivesse uma função mais burocrática, e não um papel de destaque na linha editorial do jornal.

Muitas das proposições apresentadas pelo autor parecem-nos pertinentes. Observamos em nossa pesquisa que as matérias sobre educação são encontradas por quase todo o espaço do jornal: em colunas de articulistas, em reportagens de bairro, em matérias econômicas e em artigos de opinião de políticos, acadêmicos e especialistas. $\mathrm{Na}$ falta de uma editoria que concentrasse o assunto, ele acaba por permear os outros temas abordados, o que evidencia como o discurso sobre educação escolar entremeia todo o repertório do jornal.

Nossa pesquisa restringe-se aos anos entre 1996 a 2006, e por isso estamos impossibilitados de fazer considerações sobre as décadas anteriores tratadas por Cripa. Porém, no período investigado por nós, se contabilizarmos todas as matérias que versam sobre educação, será possível constatar que houve uma grande investida no tema. Isso pode ser observado mesmo nos artigos em que o assunto aparentemente não é o foco principal, por exemplo, os textos de um empresário colunista do jornal que escreve sobre economia, mas que em seus textos quase sempre faz referências à educação de maneira bem incisiva.

A leitura da dissertação de Cripa foi-nos de grande valia, pois reforçou nossa convicção de que problematizar a análise dos enunciados que narram o cotidiano ajuda a entender as produções de determinados modos de subjetivação, ou seja, priorizar a problematização sobre a forma dos enunciados leva-nos a encontrar as racionalizações ali expostas. Deparar com descontinuidades como a apresentada por Cripa mostra-nos

\footnotetext{
${ }^{8}$ O Projeto Folha é apontado como o início do jornalismo moderno no Brasil. Teve como objetivo implantar uma nova política editorial e profissional. Estabeleceu um conjunto de medidas que instituíam normas de escrita e conduta, instrumentos de controle de produção, pesquisas com leitores, entre outros. Essas medidas tinham a intenção de formatar os padrões de comportamento profissional, editorial e gráfico. Uma frase que resume adequadamente a filosofia do jornal a partir desse projeto é: "A Folha considera notícias e idéias como mercadorias a serem tratadas com rigor técnico" (http://www1.folha.uol. com.br/folha/circulo/manual_projeto_intruducao.htm).
} 
como é fundamental entender o jogo que se processa nessa formação discursiva. Não nos dispusemos a procurar um sentido profundo nas assertivas produzidas pelo jornal, mas sim ler os enunciados em suas superfícies, as quais, por mais banais ou burocráticas que possam parecer, trazem a força de relações que se efetivam no dia a dia, em cada leitura.

Para lograr realizar uma pesquisa que se pautasse em uma abordagem menos denunciadora e mais de investigação da produção de um tipo de discurso, foi necessário lidar com as fontes desde o início da pesquisa. Isso se deu porque o objeto da análise foi construído a partir da leitura dos artigos e do manuseio do material empírico, pois a problematização apenas se concretizou com o contato direto com a série documental que, aos poucos, foi sendo criada.

\section{2 - Metodologia da pesquisa: locus, recorte temporal e seleção do material}

Iniciamos o trabalho com um mapeamento das matérias sobre educação escolar publicadas pela Folha de São Paulo. O referido jornal, criado em 1921, é publicado na cidade de São Paulo e tem circulação nacional e diária, com a produção aproximada de 302.000 exemplares por dia. É o jornal com maior tiragem e circulação no Brasil, segundo o Instituto Verificador de Circulação (IVC).

Seu crescimento deu-se principalmente a partir de 1984, devido a uma estratégia de marketing segundo a qual o jornal, identificando-se com o movimento das "Diretas Já”, conseguiu associar seu nome à campanha da redemocratização do país. Conforme Ana Lucia Novelli (2002), essa ligação de imagem/conduta conduziu a Folha a uma política de sintonização com sua clientela, conforme a proposta do projeto de modernização do jornal. Houve também, no mesmo ano, a padronização dos textos publicados com a primeira versão impressa de um Manual de Redação. Com o fito de concentrar o foco de sua atenção na satisfação dos leitores, o jornal passou a vender a imagem de ser diferente dos demais, com princípios pluralistas e apartidários, autointitulando-se crítico e independente. Esse breve retrato da Folha serve para apresentar o porquê da escolha desse veículo de informação como locus de pesquisa: além de ser o jornal com maior circulação do país, ele se autodestaca como portador de um discurso livre e desimpedido que representa a verdade - um jornal que não dá para 
não $l e r^{9}$. Independente de suas possíveis aproximações ideológicas, o que nos interessou foi justamente a importância dada por ele à informação dita verdadeira.

Faremos a seguir um recorte concernente aos interesses desta pesquisa, destacando os discursos sobre educação escolar na mídia impressa. A partir de um levantamento realizado nos arquivos on-line do jornal Folha de São Paulo, abrangendo um período de pouco mais de dez anos (01/12/1996 a 31/12/2006), selecionamos as matérias que tinham a educação escolar como temática central.

O ano de 1996 é aludido sempre que se analisa o que deve ou não ser feito na educação brasileira, isso porque em dezembro desse mesmo ano foi promulgada a Lei de Diretrizes e Bases da Educação (LDB), que passou a ser a referência legal de todos aqueles que trabalham, discutem ou vivem a educação. Assim, o mês de dezembro do referido ano foi escolhido para ser o início do recorte temporal desta pesquisa justamente porque ele inaugura uma intensa discussão no âmbito da educação escolar.

A LDB é considerada a mais importante lei educacional brasileira, um marco que revogou outras leis anteriores - como a LDB de 1961, a lei 5.540 de 1968 e a lei 5.692 de 1971, entre outras -, dando novo direcionamento à educação no Brasil. Ela tramitou no Congresso Nacional por oito anos e foi resultado de um intenso debate entre setores da sociedade civil.

A lei diz respeito ao discurso oficial do Estado, apresentando uma concepção de educação segundo a qual as práticas e os enunciados disciplinares sobre a escola transformaram-se: o espaço resguardado do ambiente escolar foi aberto e os métodos de ensino passaram a apontar para uma visão menos disciplinar.

A legislação é um dos meios utilizados para reformar sistemas e adequar instituições a necessidades e interesses de uma ordem social. A lei, portanto, é uma prática discursiva de intervenção social e, no caso da LDB/96, um instrumento que funda, propaga e faz funcionar um discurso sobre educação escolar.

A produção discursiva fomentada pelo advento da LDB/96 refletiu-se nos meios de comunicação. Ao mapear a superfície dos relatos encontrados imprensa, visualizamos de imediato numerosa quantidade de matérias publicadas a respeito da educação. Realizando um cômputo aproximado, meramente ilustrativo, registramos 80 artigos mensais cujo foco principal residia no tema da educação escolar. $\mathrm{O}$ assunto

\footnotetext{
${ }^{9}$ Slogan publicitário utilizado pelo jornal.
} 
apenas é ultrapassado, em quantidade, pelos temas da política (em média, 360 artigos) e da economia nacional (em média, 300 artigos). Levando-se em conta que aos dois assuntos mais recorrentes são reservados cadernos e colunas específicas, é possível dizer que a educação escolar usufrui, sem dúvida, de um lugar de destaque na linha editorial do jornal Folha de São Paulo.

Partindo desse levantamento, selecionamos o material para compor nossa série documental de acordo com alguns critérios: foram selecionados somente artigos que possuíam a educação escolar como temática central e que faziam menção específica à escola; foram descartados os artigos que tratavam do ensino superior, sendo que a eleição dos impressos concentrou-se no escritos sobre educação básica; outro fator que preponderou na escolha dos artigos foi a preferência pelas matérias que abordavam a educação pública, uma vez que ela recebe $85 \%$ das matrículas no ensino básico no ano de 2010, segundo o Instituto Nacional de Estudos e Pesquisas Educacionais Anísio Teixeira - INEP (BRASIL, 2010).

Esse material foi organizado por meio de um instrumento de coleta de dados: os textos foram classificados quanto ao gênero jornalístico - artigo de opinião, reportagem, entrevista ou editorial - e ordenados pelas datas de publicação e autores. Também foi realizado um mapeamento do espaço que os artigos ocupavam, o que nos indicou em quais partes do jornal e em quais épocas havia maior incidência de notícias educacionais, além de quais foram os autores mais correntes nesse tema.

Diante das numerosas matérias, foi importante estabelecer uma tática de busca que também nos auxiliou na verificação dos possíveis entrelaçamentos entre os textos. Em cada matéria, discriminamos uma ou mais palavras-chave que caracterizavam os enunciados quanto ao que se esperava da educação escolar, bem como sua importância e influência. Essas palavras-chave foram utilizadas como operadores ${ }^{10}$, instrumentos que auxiliaram na corroboração de um fio discursivo presente nas matérias analisadas.

Os operadores por nós eleitos foram: 1) qualidade, 2) formação, 3) investimento e 4) currículo. Eles foram escolhidos, em primeiro lugar, devido à pertinência na constituição de uma imagem ideal da educação escolar. Analisando os termos, podemos perceber que alguns deles apresentam uma concepção positivada. Por exemplo: ao evocar uma escola de qualidade, não é preciso expressar se o grau de excelência é

\footnotetext{
${ }^{10}$ Adaptação dos “operadores discursivos da mídia impressa” propostos por Rocha (2005).
} 
positivo ou negativo; a acepção positiva já está naturalizada. Tais elementos funcionam como princípios implícitos, pois, ao caracterizarem a escola, os enunciados têm como modelo ideal uma instituição que apresenta uma educação de qualidade, que investe na formação dos professores e que é arguida sobre a pertinência de seu currículo. Em segundo lugar, eles foram escolhidos porque são os termos de maior recorrência nas matérias jornalísticas referentes à educação. Nos artigos, reportagens e entrevistas do período analisados - em um total de mais de 3.000 matérias -, não encontramos nenhum que não fizesse referência a ao menos um dos quatro operadores em questão.

Cada operador foi utilizado como uma espécie de marcador, sinalizando, nos textos analisados, uma circunscrição de campo, definição e ordenação. Assim, os enunciados foram examinados de acordo com sua intenção de constituir uma realidade por meio da repetição. Ao mesmo tempo, utilizamos os operadores como base para a investigação sobre o que é dito e reiterado na triangulação entre educação, verdade e sujeito. Eles serviram como um fio condutor que guiou a investigação do material discursivo.

É importante dizer, ainda, que o foco da pesquisa não é a mídia, mas seus discursos. Reunimos fragmentos dos enunciados publicados e tentamos construir, seguindo a linha traçada pelos operadores, um mosaico de composições discursivas. Numa segunda etapa, analisamos esse mosaico em sua produtividade fática, levando em consideração as (des)continuidades e (ir)regularidades dos discursos. Concomitantemente, investigamos se a abundância e a repetição de ocorrências expressam o quanto certos enunciados ratificam as verdades que eles mesmos constroem, e se eles constituem princípios fundadores de práticas e de outros enunciados. 


\section{II - O PRIMADO DA INFORMAÇÃO: \\ O FATO, A NOTÍCIA, A VERDADE}

Reconhecendo o indeterminismo próprio da contemporaneidade, que Zygmunt Bauman (2007) descreve como sendo um período no qual não se tem uma perspectiva de longa duração e tudo está constantemente sendo desmontado, surpreende-nos a continuidade do discurso sobre educação impresso ao longo de uma década nas páginas do jornal Folha de São Paulo. Impressiona-nos também a legitimação que seus escritos recebem por parte da grande maioria das vozes vindas dos centros de pesquisa e das universidades do nosso país.

Se na contemporaneidade tudo é basicamente temporário, se a liquidez caracteriza o estado da sociedade atual, por que as narrações, descrições e opiniões sobre educação escolar contidas no jornal permaneceram essencialmente as mesmas no decorrer dos dez anos analisados?

Com o intuito de compreender esse aparente paradoxo encontrado num campo discursivo que possui um poder significativo de sugestão, apresentaremos uma discussão a respeito das principais linhas que caracterizam a produção da verdade, abordando sua problemática, suas regras e os procedimentos de sua veridicção.

O jornalismo, como produtor e propagador de discursos legitimados, será investigado a partir de naturalizações que operam subsidiando a formação, a atualização e a conformação de grades de compreensibilidade, as quais definem entendimentos e identificações.

\section{1 - O lineamento das verdades}

Para Nietzsche, a problemática noção de verdade não possui critérios como a evidência e a certeza, mas se trata de uma criação humana e histórica. Verdades são metáforas, assim como todas as coisas demarcadas na linguagem, e a busca por sua determinação traz em sua gênese a crença do verdadeiro como dotado de valor superior. O que é fixado como verdade é "uma designação de uma designação uniformemente válida e impositiva das coisas" (NIETZSCHE, 2009, p.29). 
A noção nietzschiana de verdade é uma das fontes das ideias de Michel Foucault. Para ele, uma verdade é uma produção histórica; são enunciados que funcionam, entre diferentes práticas, como justificação e validação racional, sendo, portanto, assumidos como verdadeiros. Não se trata aqui de questionar a veracidade da verdade, pois partimos do pressuposto de que, na linguagem, as verdades, como explica Nietzsche, são

\begin{abstract}
metáforas, metonímias, antropomorfismos, numa palavra, uma soma de relações humanas, que foram realçadas poética e retoricamente, transpostas e adornadas, e que, após uma longa utilização, parecem a um povo consolidas, canônicas e obrigatórias: as verdades são ilusões das quais se esqueceu que elas assim o são, metáforas que se tornaram desgastadas e sem força sensível, moedas que perderam seu troquel e agora são levadas em conta apenas como metal, e não mais como moedas $(2009$, p.36).
\end{abstract}

Entendemos a verdade, portanto, não como uma correspondência exata entre o conhecer subjetivo e o fato objetivo, mas como "um conjunto de regras segundo as quais se distingue o verdadeiro do falso e se atribui ao verdadeiro efeitos específicos de poder" (DELEUZE, 2006, p.13).

Esse conjunto de regras estabelece um jogo em que algumas proposições são aceitas como verdadeiras e outras como falsas. Podemos entender a manifestação da verdade como um processo que constitui subjetividades, engendra práticas e depende, fundamentalmente, de três elementos: os jogos de verdade no campo do saber (FOUCAUlt, 2006a, 2007a, 2007b, 2007c); as relações de poder que determinam, junto com os saberes, os tipos de normatividade (FOUCAULT, 2004a, 2004b, 2005a, 2006b, 2008a, 2008c); e os modos de relação consigo mesmo e com o outro que resultam nas formas de subjetivação (FOUCAULT, 1994, 1999, 2006c, 2006d). O jogo de produção da verdade constitui o indivíduo na qualidade de protagonista dessa produção, o que se dá em diferentes formas: no nível da linguagem, configura-se o sujeito falante; no nível do pensamento, o sujeito racional; e no nível do cuidado de si e do outro, o sujeito moral.

Assim, o sujeito é intrinsecamente ligado à verdade, e por meio dela tenta conhecer o mundo e nele viver. O que nos explica Nietzsche é que não há uma posse da verdade, mas apenas a conjectura de possuí-la (MACHADO, 2002). Essa relação entre sujeito e verdade não está dada a priori, é constituída a partir de relações externas. Podemos dizer, portanto, que a verdade se faz por meio de práticas, sendo que tanto o sujeito como o objeto formam-se mediante essas práticas (teóricas, científicas e de si). 
Aquilo que é normalmente aceito e reconhecido como verdadeiro não está no sujeito, não lhe é originário; constitui-se nas articulações históricas de sua configuração e modificação.

As relações de poder transpassam e produzem o corpo social, e seu funcionamento está condicionado à produção, acumulação e circulação do discurso verdadeiro. Sem essa estratégia não há exercício de poder, pois ele

\begin{abstract}
institucionaliza a busca da verdade, ele a profissionaliza, ele a recompensa. Temos de produzir a verdade como, afinal de contas, temos de produzir riquezas, e temos de produzir a verdade para poder produzir riquezas [...] somos julgados, condenados, classificados, obrigados a tarefas, destinados a uma certa maneira de viver ou a uma certa maneira de morrer, em função de discursos verdadeiros que trazem consigo efeitos específicos de poder (FOUCAULT, 2006c, p.2829).
\end{abstract}

Verdade, saber e poder operam movimentos sincrônicos, atuando desde as esferas mais íntimas do sujeito até as questões mais coletivas da sociedade. O saber é produzido nas cadeias de transmissão do poder para manter, transmitir e recriar o próprio poder. Essa relação indissociável com o saber é fruto da legitimidade que o poder necessariamente busca por meio da verdade.

Não há uma essência do conhecimento. Ele sempre está vinculado a relações estratégicas e, exatamente por essa razão, sua natureza é parcial (FOUCAULT, 2005a). Tal ideia contrapõe-se ao idealismo platônico, segundo o qual a verdade necessariamente dissocia-se do poder político, havendo uma antinomia entre saber e poder; se há o saber, ele necessariamente deveria renunciar ao poder. É precisamente a ideia que contrapõe verdade e poder político que Nietzsche propõe-se a desconstruir, evidenciando a presença do poder inerente a todo conhecimento e afirmando que, em última instância, o saber é tramado juntamente com o poder (MACHADO, 2002).

Nesse processo, autorizam-se alguns a falarem a verdade e a serem portadores de discursos iluminados; a outros, reserva-se um campo de luta, uma zona das sombras, de modo que eles podem, ou não, chegar a portar uma alegação verdadeira. Nesta pesquisa, portanto, não consideramos $a$ verdade, mas verdades.

Desse modo, não se trata de tomar a verdade no sentido cognitivo, isto é, como capacidade de conhecer mais e melhor a realidade. Nosso campo de trabalho consiste na descrição e na análise da zona de inteligibilidade em que os conhecimentos estão 
imersos. A finalidade de tal análise não é atingir a certeza e a verdade do conhecimento, mas a condição de certos saberes nos quais o discurso se articula. A questão a ser tratada é a da produção concreta dessa verdade.

Os jogos de verdade, que para Foucault (2007a) constituem discursos verdadeiros, surgem das relações entre os homens, os quais se inserem em um conjunto de disposições que regulam o modo de produção dos enunciados e suas regras de legitimidade. A regra é sempre compartilhada, sendo constituída pela convenção e pelo uso - ambos estabelecidos pelos homens no espaço social. Ela é, pois, uma produção social. Entretanto, para que tais jogos estabeleçam-se, é necessária ainda a produção de certezas e crenças fundadas na ação de dispositivos de poder, pelos quais a verdade legitima-se e inscreve-se nos indivíduos por meio da mediação de processos de subjetivação (FOUCAULT, 2004b).

Nesse jogo, processam-se a objetivação do sujeito como objeto de conhecimento e sua subjetivação nas certezas e verdades que ali se produziram. Os chamados processos de subjetivação referem-se ao modo como o próprio homem compreende-se como sujeito legítimo de determinado tipo de conhecimento, ou seja, como o sujeito percebe a si mesmo na relação entre sujeito e objeto. Os processos de objetivação, por sua vez, dizem respeito ao modo como o sujeito pôde tornar-se objeto para o conhecimento. A objetivação e a subjetivação são, portanto, processos complementares que se relacionam por meio daquilo que Foucault chamou de jogos de verdade.

Por meio da noção de regime de verdade, procuramos compreender a maneira pela qual "a verdade está ligada circularmente a sistemas de poder que a produzem e a sustentam, e a efeitos de poder que ela induz e que a reconduzem" (FoUCAULT, 2006c, p.14). Um regime de verdade define-se por um engajamento entre os sujeitos e a manifestação do verdadeiro, sendo esta constituída por um conjunto de procedimentos possíveis, verbais ou não, pelos quais se atualiza o que é estabelecido como verdadeiro em oposição ao falso.

Segundo Foucault (2006c), cada sociedade tem seus regimes de verdade, suas políticas gerais de verdades. Os efeitos desse regime estão presentes nos tipos de discurso que são acolhidos e funcionam como válidos. São os seus mecanismos que permitem distinguir os enunciados verdadeiros dos falsos; que definem a maneira como se sancionam uns e outros, as técnicas e procedimentos válidos para obtenção da 
verdade, bem como o estatuto daqueles que têm o encargo de dizer o que deve ser considerado verdadeiro.

Para o autor, essa economia política teria algumas características essenciais na modernidade:

\begin{abstract}
a 'verdade' é centrada na forma do discurso científico e nas instituições que o produzem; está submetida a uma constante incitação econômica e política (necessidade de verdade tanto para a produção econômica, quanto para o poder político); é objeto, de várias formas, de uma imensa difusão e de um imenso consumo (circula nos aparelhos de educação ou de informação, cuja extensão no corpo social é relativamente grande, não obstante algumas limitações rigorosas); é produzida e transmitida sob o controle - não exclusivo, mas dominante - de alguns grandes aparelhos políticos ou econômicos (universidade, exército, meios de comunicação); enfim, é objeto de debate político e de confronto social (as lutas ideológicas). Percebe-se, assim, que o 'regime de verdade' de uma sociedade apóia-se num suporte institucional que o utiliza para produzir e transmitir, através de seus discursos, as verdades necessárias à manutenção das relações de poder (FOUCAULT, 2006c, p.3).
\end{abstract}

Inferimos, pois, que as verdades emergem das práticas e também nelas esvaecem. Logo, toda verdade é provisória. Ela não é relativa, mas local; não se estende ao longo do tempo, não é uma má compreensão, nem um engano, é apenas algo efêmero e pontual.

O que há de fascinante em tal conceituação, a nosso ver, é que ela permite uma investigação em que não se almeja alcançar a verdade de uma época, mas os modos de funcionamento de determinadas práticas em seus detalhes, a partir das formas de enunciação, do materialmente dito - no momento, no lugar e na ocasião em que se diz.

Importam as noções de mobilidade e aproximação, o modo como o discurso isola temas e objetos, e se ajusta a conteúdos concretos. Tais conceitos podem ser vistos como constituintes de uma grade imaginária que serve para classificar, produzir diferenças e semelhanças, além de dar a ver certa configuração vigente (VEYNE, 2009). Nesse solo são construídas teorias gerais sobre a ordem das coisas.

\title{
2.2 - O jornalismo e o discurso autorizado
}

Os discursos verdadeiros precisam circular, e vários são os espaços para o fluxo contínuo de dizeres autorizados; a imprensa é um desses espaços legitimados. Na mídia 
impressa, a oferta de notícias norteia-se pela lógica da visibilidade: quanto mais informação, mais fácil é desvendar o caminho da verdade. Os relatos jornalísticos, com seus temas diversificados - política, economia, saúde, entre outros -, compõem discursos que enunciam acontecimentos, levando ao leitor uma abundante massa de informações.

Dois fenômenos são fundamentais na estratégia jornalística de disseminação de informação: a observação e a incitação. Podemos definir o campo de observação presente nos discursos jornalísticos como sendo um olhar diligente. As notícias mostram que a mirada jornalística comparece em todos os lugares: relata ações específicas, inferindo suas intenções; expõe os acontecimentos dos gabinetes legislativos, dos consultórios médicos, das salas de aula e de tantos outros lugares. Trata-se de um olhar seletivo, classificatório e produtivo, responsável por constituir discursos e opiniões que categorizam ações e práticas em nocivas ou proveitosas.

A incitação levada a cabo pelas matérias opera nesse mesmo timbre. Relata-se muito e investiga-se em grandes proporções. A constituição de um relato verdadeiro baseia-se na averiguação dos fatos, e quanto maior a quantidade de fatos relatados, mais abrangente será a apuração. Em outras palavras, quanto mais informação, mais fidedigno é o relato do acontecimento em pauta. Tal ideia, propagada e autenticada pelos meios de comunicação, autoriza a profusão de informações.

Problematizando a concepção de realidade e questionando sua unicidade, visualizamos essa profusão de notícias como um instrumento de regulação que utiliza a disseminação de informações como um diagrama de comunicação, construindo, ou mesmo produzindo, uma verdade. Podemos, assim, entender a verdade presente nesse contexto não como correspondência, mas sim como consequência de uma afirmação que tem sentido no horizonte do seu uso. Nessa perspectiva, a repetição é uma estratégia fundamental de fixação, de convencimento, de tentativa de naturalização.

O fluxo de notícias nos jornais tem como função visível a descrição de fatos; no entanto, esses mesmos fatos descritos são constitutivos do que é precariamente chamado de realidade. A questão aqui é investigar se tais descrição e ordenação de fatos não são elas mesmas produtoras de verdades, no sentido de fornecer visibilidade a ações, opiniões e dados que formam um conjunto de nomeações, o qual tem como efeito o desenho do mundo a ser visto. Afinal, nomear é isolar campos, recortando partes do mundo e atribuindo-lhe nomes. 
Atribuir nomes é ordenar a realidade; é, em outras palavras, organizar o mundo em que nos encontramos; é instituir os parâmetros pelos quais vemos, entendemos e agimos. Se compreendermos que as criações podem ser diversas e que não existe uma essência primeira a ser revelada, podemos dizer que os relatos criam realidades construídas em bases empíricas e comprovadas, mas que podem ser integradas conforme os novos saberes instituídos.

Os regimes de verdade, como já discutido aqui, são conjuntos de práticas, discursivas ou não, capazes de inscrever verdades naquilo que se chama de realidade. Neles podemos identificar discursos que funcionam como verdadeiros; mecanismos e instâncias que permitem distinguir entre sentenças verdadeiras e falsas; técnicas e procedimentos valorizados na aquisição da verdade; e o status daqueles que estão encarregados de dizer o que é tido como verídico (FouCAULt, 2005a).

Como os discursos são formas de narrar o mundo, neles está delineado, como parte inseparável, um mundo a ser vivido. Ao empreender tal narração, as matérias jornalísticas estabelecem valores, legitimando regras e produzindo significados ao mundo. O discurso, no sentido foucaultiano, é uma prática constitutiva de outras práticas, e que se forma no interior dela mesma. Os fatos que circulam diariamente na mídia impressa são um dos meios de propagação dessas falas, possuindo uma importância estratégica como o espaço no qual os discursos terão um considerável ponto de visibilidade.

De acordo com a perspectiva foucaultiana, podemos dizer que os fatos e as descrições apresentados pelo jornalismo correspondem a coordenadas de um mapa, quadriculando o mundo em eixos verticais e horizontais. A imprensa é, portanto, um sistema de informação que opera com palavras de ordem. Como explica Deleuze,

informação é um conjunto de palavras de ordem. Quando nos informam, nos dizem o que julgam que devemos crer. Em outros termos, informar é fazer circular uma palavra de ordem [...]. Elas nos comunicam informações, nos dizem aquilo que julgam que somos capazes ou devemos ou temos a obrigação de crer. Ou nem mesmo crer, mas fazer como se acreditássemos. Não nos pedem para crer, mas para nos comportar como se crêssemos. Isso é informação, isso é comunicação; à parte essas palavras de ordem e sua transmissão, não existe comunicação. O que equivale a dizer que a informação é exatamente o sistema do controle $(1999$, p.5). 
A expressão palavras de ordem, tal como utilizada no contexto do pensamento de Deleuze, não significa o mando formal no modo imperativo, a expressão de comando direto, mas o vínculo dos enunciados com presunções subentendidas. Essas considerações implícitas que transpassam os assuntos abordados atuam como agentes de uma ordem estabelecida de subjetivação e legitimam-se se houver consonância com um solo de significações - se houver ressonância, como dizem Deleuze e Guattari (2008).

Os jornais e as notícias dizem-nos, portanto, o que é essencial "pensar, reter, esperar... uma vez que o enunciado realiza um ato e que o ato se realiza no enunciado" (DELeuZE; GuATTARI, 2008, p.17). Mas devemos ter o cuidado de não nos deixar guiar por uma percepção que consagre ao jornalismo, e à mídia em geral, um papel de oráculo. Ele está inserido em toda uma rede de relações, discursivas ou não, a qual opera por meio de uma convocação coletiva. Trata-se, pois, de um mecanismo que atua e produz, sempre em conflito entre posições que acarretam embates e consensos, interdições e autorizações, inclusões e exclusões, num jogo de fricções que impele suas ações, respeitando e invadindo fronteiras delineadas conforme demandas, necessidades de administração e gerência de condutas. Esse movimento veemente é perpassado por forças que elegem diferentes palavras de ordem, grades de significações e processos de subjetivações, estabelecendo regimes de verdade.

Utilizando uma metáfora deleuziana, em tal sistema de controle não há mais a necessidade de cercas, nem de muros; o monitoramento é feito por meio de construções de estradas que não enclausuram, nas quais as pessoas podem andar livremente, escolhendo seus caminhos, mas seguindo orientações estabelecidas que possibilitam múltiplos meios de controle (DELEUZE, 1999). As estradas estão assentadas sobre a intuição de verdade, ou seja, sobre os relatos baseados em um instinto da crença na verdade, necessária ao homem em suas relações com outros homens (NIETZSCHE, 2009).

As verdades apresentadas têm uma intrínseca relação com outros discursos, pois são um "conjunto do dizível, histórica e lingüisticamente definido" (ORLANDI, 1992, p.89). Assim, o regime de verdade apresentado pelo jornal está ancorado num já dito que o identifica como natural.

O texto com pretensões de verdadeiro deve ser fundamentado em formas racionais de saberes, e muitas vezes é fortalecido por testemunhos (FOUCAULT, 2005a) uma prática comum nos relatos jornalísticos. 
A produção e a fixação da verdade, nesse caso, processam-se por meio de uma espécie de confissão dos protagonistas da situação. Se em determinadas situações os sujeitos identificam sua verdade por meio de outros - por exemplo, pelas sentenças dos especialistas -, quando o testemunho de professores e alunos é convocado, inicia-se um processo pelo qual o sujeito é chamado a falar de si. Trata-se de uma enunciação do eu (FOUCAULT, 1997), estratégia que se constitui num engajamento do sujeito em relação à verdade que manifesta, configurando um aliciamento que o leva a tornar-se o que ele próprio confessa ser. Ao vincular o sujeito à obrigação de verdade daquilo que ele mesmo anuncia, a enunciação o qualifica como um professor sofrido, um aluno revoltado etc., e faz com que ele se dobre diante de sua própria história, reconhecendose numa série de identidades constituídas por episódios concernentes à sua existência.

A ação de abrir espaço para a confissão age em duas direções: no individual, engaja o sujeito na verdade; no coletivo, cria algo cuja existência não pode ser contestada, legitimando assim uma verdade proveniente diretamente de seus participantes.

Um regime de verdade apresentado na impressa é uma prática discursiva que atua como realidade, conformando outras práticas e subjetividades. Junto com Foucault, podemos afirmar que os discursos que perpassam as sociedades são produções com delimitações e procedimentos de controle internos e externos, os quais compõem os jogos de verdade numa dinâmica instável muitas vezes pautada pela causalidade e pela fatalidade, o que concede ritmo aos lances e disputas que delineiam as relações de poder.

A comunicação de massa tem um papel fundamental na construção de consensos e legitimidades; sua posição de produtora e propagadora de discursos autorizados constrói significados. Podemos dizer que a mídia opera regimes de enunciação fundamentados em ordens de visibilidade e enunciabilidade. Neles, o sujeito defronta-se com objetos que se fazem presentes justamente por serem construídos pelos discursos que os descrevem, sendo visíveis e compreensíveis apenas segundo esse conjunto de enunciados. Nesse jogo de discursividades, contornos são flexíveis, deslocamentos, necessários e rupturas, inevitáveis; no entanto, sua fundamentação é tão bem arquitetada que o sentido que percebemos nas coisas e muitas de nossas certezas são naturalizações construídas pela ordem de um discurso. 
Entendemos o jornalismo como uma prática social na qual os sentidos são constituídos e reforçados, numa relação dialógica. A linguagem da mídia é ação, é performativa; no seu discurso, há sempre movimento - acusações, perguntas, justificativas - produzindo posicionamentos dos interlocutores. Um enunciado jornalístico é um elo de uma corrente de enunciados organizados sofisticadamente, inseridos em regimes de verdade já existentes que se ajustam, coadunando as nuanças do novo.

O jornal, um documento de domínio público, faz circular conteúdos de um tempo e de um contexto específicos, formando e sendo formado pelo repertório de seus leitores e colaboradores. Trata-se, portanto, de um dos componentes significativos do cotidiano. A legitimidade dos dizeres jornalísticos é uma condição importante para que os escritos ali impressos sejam considerados verdadeiros. Essa legitimidade provém de alguns atributos indispensáveis ao jornalismo, como a autoridade, a produtividade e a credibilidade (MEDRADO, 1999), condições alcançadas graças a um conjunto de fatores: as ideias dos colunistas - profissionais que trabalham regularmente para o jornal, produzindo textos não necessariamente noticiosos denominados colunas -, suas linhas de argumentação, as razões e informações que sustentam seu ponto de vista. Outro aspecto é a necessidade de a notícia não vir a ser falseada futuramente; para isso, as reportagens apoiam-se tanto em depoimentos de pessoas que viveram ou produziram os fatos narrados, quanto em fontes acadêmicas e oficiais, o que confere confiabilidade às informações. A legitimidade dos textos jornalísticos está fundamentada, pois, nas vozes que concedem às descrições, relatos, opiniões e proposições a qualidade daquilo que é crível.

O jornalismo não é o objeto central desta pesquisa, mas julgamos interessante traçar uma apresentação resumida para contextualizar a instrumentalização das informações que a imprensa oferece como notícia.

De acordo com Maria Aparecida Baccega (2001), o mundo apresentado pelos relatos jornalísticos é editado, ou seja, produzido num trajeto repleto de mediações. $\mathrm{O}$ processo de edição de uma matéria é feito por meio da seleção, da autorização e da interdição de informações: em primeiro lugar, ocorre a definição da pauta - a escolha do assunto a ser abordado -; depois, a escolha das fontes - quem vai falar -; por fim, a diagramação - elaboração do formato e de demais elementos presentes na notícia (textos, legendas, fotos e ilustrações). 
Vários fatores interferem nos critérios de produção e organização das matérias, como explica Juarez Bahia:

Não é só o valor da notícia como produto de apuração e como informação útil que está em jogo na seleção do editor, por exemplo. Aspectos como veracidade, legalidade, oportunidade, peso social, interesse particular, relevância, consequência, interesse e credibilidade influem na publicação (1990, p.42).

A notícia, então, é parte de um discurso produzido por edições de informações, dados estatísticos e pesquisas acadêmicas que derivam de um rol de enunciados. Estes, por sua vez, originam e configuram um entrelaçado discursivo que sanciona e legitima a ideia de educação e os pensamentos sobre a instituição escolar que circulam na sociedade. O discurso educativo é "um conjunto de enunciados que se apoia em um mesmo sistema de formação" (FOUCAULT, 2007b, p.122).

Não compete a este trabalho denunciar um suposto escamoteio de informações, nem apontar possíveis interesses particulares motivadores das pautas abordadas, informações conflitantes, denúncias sem fundamento, ou outros aspectos presentes no jornalismo, como descreve Manuel Carlos Chaparro (2007). Nossa problematização parte da ideia de que um mundo educacional é editado e assim ele chega a todos nós; de que sua edição obedece a normas, interesses e relações de diferentes tipos, e que, desse modo, acabamos por perceber nosso entorno do modo como ele foi editado. Editar, aqui, não se refere à reconstrução ou transformação de uma dada realidade, mas à constituição de uma realidade por meio do entrelaçamento de fatos, valores e intenções veiculadas num instrumento responsável por fazer circular as proposições dali derivadas, instrumento esse que se baseia em dois pilares fundamentais: a informação e a liberdade, os quais, coincidentemente ou não, são tidos como alguns dos pilares da democracia e da atuação autônoma dos cidadãos.

Nossas discussões localizam-se para além de questões acerca da veracidade ou falsidade das informações; o panorama dos discursos sobre a educação aqui descrito é resultado dos textos impressos no jornal que se movem e são naturalizados na e pela sociedade. Nenhuma das notícias utilizadas neste trabalho causa estranheza ou mostrase inédita, e interessa-nos justamente investigar que tipo de sujeito elas engendram e quais funções da educação são destacadas. Transpondo a discussão sobre verdade e mentira, podemos dizer que os enunciados da impressa narram fatos e acontecimentos que são aceitos como verdadeiros sobre nossa realidade educacional; ao atuar em 
consonância com demais elos institucionais, tais enunciados delineiam, de um modo particular, o que é a educação, o que lhe falta e o que deve ser feito em relação a ela.

Confrontar-se com esse discurso, promovendo um estranhamento de seus enunciados, leva-nos a questionar o porquê dessa tentativa de ingerência no âmbito escolar. Qual é a razão de se caracterizar a educação, principalmente a pública, desse modo específico? Em um movimento de desestabilização de uma narrativa acordada e plenamente admitida, fizemos um mapeamento da produção dessas referidas verdades na estreiteza e na singularidade em que elas se conformam.

O discurso, como já dito, é uma prática, é a instância da linguagem em que a língua está relacionada a algo que não é linguístico. Essa relação com esse algo, que se dá no uso da linguagem, é o discurso. Os textos jornalísticos são mostra daquilo que Foucault denomina prática discursiva.

Não podemos confundi-la [a prática discursiva] com a operação expressiva pela qual um indivíduo formula uma idéia, um desejo, uma imagem; nem com a atividade racional que pode ser acionada num sistema de inferência; nem com a "competência" de um sujeito falante quando constrói frases gramaticais; é um conjunto de regras anônimas, históricas, sempre determinadas no tempo e no espaço, que definiram, em uma dada época e para uma determinada área social, econômica, geográfica ou lingüística, as condições de exercício da função enunciativa (2007b, p.133).

Entendemos que, onde quer que haja discurso, haverá disciplina e controle, numa retroalimentação constante. Ele é, pois, parte fundamental desse intricado jogo no qual formamos e somos formados constantemente. 


\section{III - A EDUCAÇÃo ESCOLAR EM PAUTA}

Os grandes jornais diários são ótimas vitrines das idas e vindas dos sentidos que colonizam o cotidiano. Nesta dissertação, não nos interessou a veracidade das informações oferecidas, mas o modo como cada reportagem, cada artigo, posicionavase; quais eram suas finalidades; qual o propósito da utilização de depoimentos de autoridades e pesquisadores; o que os professores, alunos e gestores presentes nos textos impressos contavam-nos sobre a escola.

Quando se leem páginas de um jornal com a intenção de buscar as informações nelas divulgadas, ou seja, quando se considera a apregoada função informativa desse meio de comunicação de massa de apresentar os fatos ao leitor, é possível convencer-se de que ali se pode apreender a realidade. Os acontecimentos narrados são coerentes com o que conhecemos, com o que nos é dado a ver, com uma matriz de inteligibilidade que nos ajuda a encontrar sentido nas notícias que nos chegam.

O sentido, elaboração tão minuciosa quanto volátil, é social, uma composição coletiva e interacional por intermédio da qual é possível reconhecer termos e criar encadeamentos que parecem coerentes e lógicos, facilitando, assim, a lida com circunstâncias, acasos e acontecimentos.

O jornal, como propagador de sentidos, estabelece tessituras que relacionam o indivíduo à verdade, aquela defendida em suas páginas. Ele apresenta-nos uma imagem ideal do que deveria ser a instituição escolar confrontando-nos com uma escola dita real que, muito aquém das expectativas, mostra-se triste, incompetente e abandonada.

Neste capítulo, apresentamos uma análise do material selecionado na tentativa de visualizar "aquilo que rege os enunciados e a maneira como eles se regem entre si para constituir um conjunto de proposições aceitáveis" (FoUCAULt, 2006c, p.4), quais as relações que se processam nesse jogo e que modelo de sujeito está sendo projetado e edificado. 


\section{1 - Um briefing panorâmico}

A mídia impressa está autorizada a descrever, prescrever e ajuizar o panorama educacional? Como a escola é narrada? Quem a descreve? Uma análise da superfície das matérias jornalísticas identifica dados interessantes.

O discurso jornalístico sobre educação escolar caracteriza-se, na década pesquisada, por um caráter propositivo, seguindo o movimento de relatar fatos para, em seguida, propor ações reparatórias ou reformadoras. Os assuntos pertinentes ao tema são distribuídos uniformemente no decorrer dos dez anos analisados, não havendo nenhuma predominância significativa de um assunto sobre outro, o que parece demonstrar uma regularidade consistente e concentrada das preocupações da mídia jornalística em relação à escola.

Nos artigos selecionados, os assuntos mais abordados foram: 1) a educação como a principal solução para os problemas de desenvolvimento do país e de bem-estar da população; 2) a formação do professor; 3) a questão da avaliação; 4) o problema da qualidade; 5) a violência e 6) a dicotomia entre a educação pública e a privada.

A maioria das reportagens sobre o tema educacional encontra-se no caderno Cotidiano, fração do jornal que oferece aos leitores informações do dia a dia, principalmente nas áreas de segurança, educação e saúde. Trata-se de um caderno que se utiliza da heterogeneidade dos acontecimentos cotidianos para noticiar e dissertar sobre vários assuntos interligando os fatos diários, como a conexão da criminalidade com pautas que abordem as escolas ou artigos que relatam aspectos da aprendizagem escolar relacionados à saúde.

Os artigos de opinião, textos de autores convidados ou colunistas do jornal, são aqueles em que o escritor expõe seus posicionamentos diante de algum tema. Geralmente, são textos dissertativos que apresentam argumentos sobre o assunto abordado, sendo que o autor, além de expor seu ponto de vista, sustenta-o por meio de informações coerentes e admissíveis. Os artigos desse tipo estão difundidos por vários cadernos, obedecendo a um ordenamento lógico: se o autor é colunista do jornal, seu artigo sai no caderno da sua própria coluna; caso seja um autor convidado, seu texto é publicado no primeiro caderno, na seção Opinião. O caderno que mais apresentou artigos assinados sobre educação no decorrer do período pesquisado, à exceção do 
Cotidiano acima citado, foi o Dinheiro, seção do jornal dedicada à conjuntura econômica brasileira e mundial, composta por reportagens e artigos assinados.

Encontramos também cadernos especiais dedicados à educação, geralmente publicados no último e no penúltimo trimestres do ano. Esses cadernos configuram-se como manuais de auxílio aos pais na escolha de uma escola para seus filhos. Entremeados de dicas e informações sobre métodos pedagógicos e linhas disciplinares, são dirigidos principalmente aos clientes das escolas privadas, abordando apenas superficialmente as instituições públicas.

A abundância discursiva sobre o assunto apresenta características regulares e uniformes. Podemos classificar os relatos selecionados em três tipos: prescritivos, preventivos e denunciativos. Tal divisão é tão somente uma maneira de explicitar as disposições predominantes, pois essas três características muitas vezes aparecem simultaneamente nos textos. Os relatos prescritivos explicam, entre outras coisas, como fazer a escola funcionar de um modo supostamente correto, transmitindo a receita de um ensino produtivo e revelando fórmulas de capacitação continuada. Os denunciativos comunicam o descaso das autoridades públicas com a educação, anunciam as improbidades com o erário destinado a ela, revelam as diversas formas de violência presentes nas escolas e alertam para a pouca qualidade da educação pública, enunciando a alta probabilidade de uma formação precária dos alunos. Finalmente, os relatos preventivos oferecem um conjunto de medidas que visam prevenir o mal anunciado, tais como: a intervenção das empresas do terceiro setor como uma solução para implantar a qualidade, ou mesmo a opção de seguros, os quais servem para gerir o risco de o aluno da escola particular (apresentada como bem mais eficiente) migrar para a pública.

As vozes ali encontradas são múltiplas e quase nunca dissonantes. Uma vez que o discurso é bastante regular e praticamente sem rupturas, apresentando somente sofisticações de análise, o fator diversidade vem da escolha das testemunhas e dos analistas. Utilizando uma divisão arbitrária apenas para facilitar a classificação dos dados - como já foi dito, todos os elementos são mesclados no corpo das matérias -, podemos separar as vozes em três grandes blocos.

O primeiro deles é formado por personagens diretamente ligados à educação escolar: professores, alunos, coordenadores/supervisores e pais. Nesse segmento, o mais comum são depoimentos que relatam fatos da escola, opiniões, indignações, concordâncias etc. Como exemplo, podemos citar o depoimento de alunos e professores 
descrevendo os fatos narrados no artigo, expediente esse que serve para legitimar aquilo que se diz.

O segundo bloco é integrado por especialistas que não estão ligados diretamente à lida escolar. Nesse bloco, temos professores universitários, pesquisadores de fundações estatais e de organizações da sociedade civil, psicólogos, médicos e funcionários de organizações internacionais voltadas à educação, enfim, uma numerosa quantidade de profissionais que se dedicam a analisar o funcionamento das práticas escolares. Sua participação se dá por meio de comunicações de pesquisa que visam autenticar ou refutar informações, além de depoimentos cientificamente legitimados.

Já no terceiro, temos o estamento dos formadores de opinião, comentaristas supostamente qualificados da vida e da sociedade. Suas ideias podem, a partir da ordem do discurso, reprimir ou fazer circular alegadas verdades. Encontramos aqui o relato da informação caracterizado como um espetáculo no qual as ideias do formador funcionam como uma convocação. Sua opinião, apesar de não ser de um especialista, é altamente valorizada. Participam desse bloco principalmente jornalistas e empresários, e suas matérias são sempre artigos assinados.

As vozes autorizadas a proferir a verdade sobre a escola buscam assegurar uma espécie de salvação de um mundo escolar desprovido de eficiência e serventia. Suas falas são de um timbre afirmativo no sentido de fazer o bem, indicando o melhor para uma instituição secular e fundamental. Podemos dizer que elas assumem um papel de cuidado do bem-estar educacional. Os especialistas e os formadores de opinião apresentam denúncias, cobram atitudes, examinam opções. Suas falas são ancoradas na prescrição de como se alcançar uma boa educação.

As afirmativas oferecidas em tal campo de informação estão inseridas em um jogo de correlações e dominâncias que as verdades constituem, bem como as interdições e as autorizações compostas por elas. $\mathrm{O}$ instigante nessa abundância discursiva, segundo pensamos, é investigar em quais outros discursos essas vozes estão pautadas, do que se fala e como se distribui essa fala; esquadrinhar quais são as práticas que as incitam, quais são as vontades que conduzem esse discurso, quais são as intenções estratégicas que o sustentam e o que está sendo posto em jogo.

O jornal, um dos produtores da cultura contemporânea, é parte integrante e geradora da sociedade. Este módico estudo feito sobre as matérias selecionadas sobre 
educação escolar constatou que, por elas, circulam prescrições afeitas à produção de determinados tipos de identidade, seja para a instituição escolar, para seus participantes (alunos, professores, diretores e coordenadores) ou mesmo para o processo de educar. Tais prescrições corroboram a necessidade vital de um tipo de educação escolar voltada para a manutenção e o aperfeiçoamento do tipo de sociedade em que vivemos. Além disso, esse movimento de prescrição, descrição e narração consolida-se como um dispositivo de gerenciamento de formas de entender o mundo, de ser e de nele atuar.

Quando os textos jornalísticos abordam temas pertinentes à educação, eles fornecem um modo específico de conceber a vida, modo este que contém sugestões, debates e diretrizes de competências escolares adequadas a determinado olhar. A questão principal é que, invariavelmente, essa visão mapeia um cenário que se pretende único, obliterando a visualização de outras paisagens.

Transpondo o pensamento de Marisa Vorraber Costa sobre a mídia televisiva para a jornalística, podemos dizer que os artigos do jornal visibilizam "significados consonantes com projetos políticos, sociais e culturais hegemônicos, colocando em funcionamento técnicas de governo que forjam consciências e moldam condutas" (2002, p.73). Como a autora, concordamos que as heterogeneidades fazem parte desse jogo discursivo e que os leitores não são elementos passivos de um “inescapável determinismo" (p.73); porém, nesse cotejo do discurso autorizado, as "respostas são incitadas e condutas são modeladas e performadas" (p.73), não num movimento alienante de obscurecimento da realidade e instauração de uma representação utilitarista dos fatos, mas numa relação dialógica na qual interagem aceitação, recusa e convencimento.

Operando também segundo uma regra de fixação (FOUCAULT, 2002), o discurso jornalístico sobre educação propaga-se como uma campanha, o que se dá principalmente devido à quantidade de artigos, matérias e entrevistas publicados e à aparente regularidade de suas conclusões. Em primeiro lugar, os artigos investem na culpabilização da escola, do sistema educacional, dos professores e dos alunos pelo chamado fracasso da educação, recorrendo a gráficos e pesquisas estatísticas. Tais artigos expõem a falta de civilidade dos alunos, a ineficiência nas avaliações e a ausência de boa formação e capacidade dos professores.

$\mathrm{Na}$ especificação do fracasso, revés dos agentes e da instituição, conclui-se que tal malogro ocasiona um baixo desenvolvimento das competências da população em 
geral, reduzindo a formação de profissionais qualificados e a produção de pesquisas científicas, e resultando, enfim, em um atraso tecnológico, econômico e social. A campanha segue no sentido de transformar o fracasso da educação escolar do país em um agente de subdesenvolvimento, má distribuição de renda e criminalidade, entre outros fatores.

Os textos investem também numa espécie de ordenamento em que são enumerados erros e limitações de alunos, professores e gestores da instituição - uma ação que instiga a visualização da fragilidade educacional, lapidando a necessidade de aprimoramento. O mais interessante desse cenário rascunhado é que quase invariavelmente esse roteiro refere-se à educação pública, reservando à privada uma aura de eficiência. Isso produz uma dicotomia e uma série de pensamentos derivados dela, como a ideia de que a educação oferecida pelas instituições privadas é muito mais eficaz do que a proporcionada pelo Estado. Essa espécie de campanha instala, em conjunto com outros campos discursivos, verdades aceitas e reconhecidas, como o fracasso, a ineficiência e o abandono da escola pública.

O discurso da mídia impressa também efetiva uma espécie de pedagogização, ensinando aos leitores, contando-lhes histórias, mostrando-lhes como as coisas deveriam ser, prescrevendo-lhes jeitos corretos ou incorretos de ser e de fazer. Tais conteúdos, repetidos e fixados, são parte de uma teia de comunicação que delineia uma estrutura racional, lógica e maleável. Os argumentos apresentados possuem um estatuto de cientificidade e funcionam como um discurso de verdade formulado por pessoas alegadamente qualificadas, as quais são legitimadas como porta-vozes dos saberes.

O jornal opera, nesse sentido, por meio da circulação de informações e da produção de imagens e significações que, de vários modos, dirigem-se à educação dos leitores. A escola e a educação são significadas e estabelecidas por um repertório de dados, depoimentos e análises, os quais fazem desse veículo um lugar fundamental de elaboração e circulação de um conjunto de valores e concepções relacionados "a um aprendizado cotidiano sobre quem nós somos, o que devemos fazer com nosso corpo, como devemos educar nossos filhos, de que modo deve ser feita nossa alimentação diária” (FISCHER, 2002a, p.153).

Ao associar a regularidade e a profusão de matérias sobre educação no período pesquisado, ponderamos que, em vez de haver uma regulação baseada na repressão combinação normalmente elencada quando se trata de discorrer sobre relações de 
dominação -, o que se vê é uma forma de direção fundamentada no convencimento, convocando os leitores a um exercício permanente de reconhecimento, reflexão e posicionamento perante a educação.

A fim de que essa produção de uma verdade sobre a escola opere com êxito, é determinante que se proceda a um ato de verificação. Para tal, faz-se necessário um resgate testemunhal do que ali se passa, uma marca do olhar que pretende remontar o que ocorre dentro dos muros que delimitam o espaço escolar. Como testemunhas, são convocados professores, alunos e gestores que contribuem com a (re)construção do olhar (FouCAULT, 2005a). Assim, a produção da verdade transita entre o que é afirmado pela análise do especialista e pelo depoimento dos atores escolares, segundo um processo em que se busca a elaboração de formas racionais de narração aliadas a um procedimento de persuasão. Tal procedimento é necessário no interior dessa produção para convencer as pessoas daquilo que é dito, pois elas participarão da autenticação do discurso.

O discurso jornalístico apresenta uma polifonia de vozes e uma uniformidade de conteúdo; sua orientação configura-se como uma fita de Moebius, de movimento cíclico e ritmado, apresentando argumentos que se encontram algumas vezes de um lado, outras, de outro. Compõe-se, assim, um jogo de bases implícitas, contrapondo ideias que se confrontam na forma, mas que estão presas às mesmas essências.

O interessante nessa regularidade é que o discurso jornalístico afirma caracterizar-se pela aptidão de incorporar e mediar os discursos de vários sujeitos e processos sociais, de compor um cenário de confrontos, criando uma salutar competição entre as fontes que querem ver publicados os seus conteúdos. Era de se supor, portanto, que houvesse uma constante luta entre discursos, na busca de interpelar o sujeito e de conquistá-lo com uma visão de mundo e com uma produção de sentidos realizada a partir de um jogo de influências. No caso da educação, porém, os relatos são uníssonos. Dessa forma, o veículo de comunicação não se torna um meio privilegiado para o confronto dos discursos, mas um meio para sua fixação. Ninguém, nenhuma voz, diz que a escola funciona na medida exata para a qual foi programada; não há, por exemplo, hipóteses de uma educação não escolar, ou mesmo de uma não educação.

À regularidade dos enunciados somam-se os vários fenômenos do discurso jornalístico sobre educação escolar apresentados neste capítulo: a incitação, a visibilidade, a repetição, a fixação e a legitimação. O discurso da imprensa diária - no 
caso, a Folha de São Paulo - move-se da observação à descrição, apresentando cálculos, recorrendo a prescrições e caracterizando-se como uma formação discursiva (DELEUZE, 2006).

A relação entre discurso e sujeito é essencial para apreender todo um processo de condução de condutas. Imbuídos do pensamento de Foucault, podemos afirmar que o discurso é um conjunto de enunciados e que se caracteriza por oferecer uma posição a ser ocupada pelo sujeito, por apresentar um campo no qual suas proposições coexistam com outros enunciados e por possuir uma materialidade própria (FOUCAULT, 2004a). Os textos do jornal são afirmações de fatos, os quais não existem isolados, mas sempre em associação e correlação com outros enunciados em formas muito concretas.

O discurso educativo oferecido na mídia distingue-se por uma conformação específica no espaço. Ele se associa a outros enunciados numa ação transversal, ou seja, ele transpassa e é transpassado por outros enunciados (econômicos, políticos, sociais), fazendo parte de suas construções. É comum, por exemplo, encontrarmos matérias sobre educação em que a economia e a conjuntura política fazem parte do embasamento lógico apresentado nos argumentos utilizados. Do mesmo modo, os cadernos específicos de economia e política são repletos de artigos que abordam a educação e suas configurações, enaltecendo um caráter essencial e determinante.

Outra relação que os enunciados apresentam é a de correspondência entre seus sujeitos, objetos e conceitos, o que revela uma interdependência entre eles. Há aí um movimento incessante de constituição de identidades, ou seja, um processo de subjetivação contínuo e de construções identitárias compostas de valores e aspectos sociais e históricos procedentes de um requintado campo de práticas discursivas e não discursivas. Para a efetiva produção de verdades, é preciso que haja convergência entre o que se fala - enunciados -, o que se vê - visibilidades - e o que se entende - grade de inteligibilidade. O jornal atua nesse campo com ferramentas importantes para a constituição de sentidos e a circulação dos enunciados.

Existe assim uma relação extrínseca e complementar com outros espaços, como instituições, acontecimentos políticos e processos econômicos. Nesse aspecto, os enunciados remetem a um meio institucional sem o qual não haveria nem o objeto (educação), nem os sujeitos que falam daquele lugar (professor, aluno etc.). Tal movimento processa-se num recorte diagonal, ou seja, os enunciados relacionam-se com a instituição constituindo um ideal, um horizonte determinado. Os textos jornalísticos 
sobre alunos, professores e educação abordam, entre outros assuntos, a formação, a competência e a avaliação. Dessa forma, eles reforçam campos de objetos, como população, produção e comportamento, os quais se referem a modos de gerenciamento e a estratégias que enquadram e fiscalizam, produzindo uma relação prática e política do discurso educacional.

No locus escolhido - a mídia impressa -, configura-se um campo discursivo: local de combate e disseminação de regimes de verdade que possui a capacidade de descrever, prescrever e narrar, conformando opiniões, capturando atenções, oferecendo versões, produzindo histórias, enfim, interpelando.

É possível afirmar que a contemporaneidade empenha-se na direção da garantia dos direitos humanos, da vida, da dignidade e do respeito às diferenças, reforçando a defesa de uma fruição pessoal e executando com maestria uma transferência da noção de bem para aquela de bem-estar. Esse processo perfaz discursivamente um quadro social específico; trata-se de uma apresentação do mundo baseada nos modos pelos quais este deve ser vivido. Aquilo que é dado a ver nesse cenário define-se por uma educação dos sentidos e da razão - uma educação em valores, dito de outro modo. Tal quadro fornece-nos a dimensão do jornalismo na organização social, explicitando sua importância como ponto estratégico de produção e de difusão de certos discursos.

Está feito o convite para nos embrenharmos pelos enunciados sobre a educação escolar a fim de visitar as micro-operações ali em funcionamento. Na paisagem do discurso jornalístico, buscaremos apreender qual escola é descrita, produzida e analisada; como essa enunciação é elaborada; quem fala sobre ela e quais futuros lhe são prognosticados.

\section{2 - A identidade arquitetada da escola}

O texto jornalístico, composto de conjecturas, relatos e prescrições, impõe-senos como um aliciante campo de estudos. Há em sua composição um convite ao jogo de análise e, concomitantemente, à incursão pelas frases e palavras ali em uso. Sem a intenção de decifrá-las, vemos a possibilidade de perseguir linhas de tensão que se apresentam em movimentos ondulatórios e compõem relações de poder-saber numa rede espraiada de gestão de condutas. 
A problematização aqui apresentada não foi construída com a preocupação de examinar os documentos à exaustão, dissecando-os em suas minúcias. Interessou-nos, a partir das repetidas leituras de cada texto, salientar aquilo que insistia em reaparecer nos relatos e nas prescrições: o jogo das proposições e a contingência das ações expostas nos artigos. Ao longo do percurso, fomos acompanhados pela "inquietação diante do que é o discurso em sua realidade material de coisa pronunciada ou escrita" (FOUCAULT, 2004a, p.8).

Os enunciados examinados apresentam o que chamamos de verdades sobre a educação escolar; estas se constituem por um estilo de raciocínio configurado a partir de relatos e pesquisas, sendo ratificadas por depoimentos, estatísticas e estudos acadêmicos. Uma análise sobre como tais verdades são processadas na mídia jornalística evidencia um conjunto de discursos que atuam em consonância com instituições, utilizam-se de enunciados cientificizados e ressoam proposições morais. Em outros termos, o que se vê é uma rede de relações operacionalizadas por uma máquina discursiva que produz, reitera, fundamenta, racionaliza, justifica e autoriza enunciados, adensando processos e naturalizando (generalizando) regularidades.

Trata-se, pois, de verdades apoiadas na cientificidade, referendadas e validadas por especialistas, e com a capacidade ou o intuito de serem obedecidas. Elas atuam como um regime discursivo inteligível. Isso se dá porque os pensamentos processam-se dentro dos limites dessas verdades, de forma que os indivíduos reconhecem como verdadeiro aquilo que é dito e escrito no interior desse gabarito.

Tais aspectos impelem-nos a não considerar essas verdades como sendo verdadeiras; porém, também não as consideramos falsas. Entendemos que são verdades produzidas e, simultaneamente, produtoras de efeitos.

A fim de problematizar a noção de educação escolar oferecida pelos relatos jornalísticos, foi necessário tomar um distanciamento em relação a ela e contornar suas evidências familiares, analisando as naturalizações que se processam nessa rede de enunciados. Para tanto, utilizamos como ferramenta analítica a noção de tecnologia concebida por Foucault, a qual foi definida por Nikolas Rose como

qualquer conjunto estruturado por uma racionalidade prática $\mathrm{e}$ governado por um objetivo mais ou menos consciente. [...] são montagens hibridas de saberes, instrumentos, pessoas, sistemas de julgamento, orientados, no nível programático, por certos pressupostos e objetivos sobre os seres humanos (2001a, p.38). 
Tal concepção ajudou-nos a entender o funcionamento do discurso contido nos textos jornalísticos, uma vez que estes são constituídos pela articulação de diferentes estratégias e mecanismos enredados em formas de articulação de saber-poder. Neles estão contidos tanto o controle dos corpos e das almas, quanto a produção de modos de ser, falar e comportar-se.

A racionalidade enunciada nos artigos constitui um conjunto de procedimentos e saberes considerados desejáveis e úteis para a conformação de sujeitos que saibam dirigir suas próprias condutas; trata-se de uma sofisticada condução de condutas que visa a si e aos outros. A questão que se impõe nos enunciados sobre educação escolar apresentados pela mídia jornalística pode ser descrita como uma demanda de intervenção: instrumentalizar e tornar factível a ação sobre aquilo que se almeja e se esquematiza.

A partir da leitura dos documentos selecionados, defrontamo-nos com numerosas análises acompanhadas por prescrições de experts e por relatos de fatos que legitimam a ideia de uma crise, por meio da constatação do fracasso da escola em suas intenções educacionais. É impressionante a regularidade presente nas argumentações e a abundância de proposições sobre os procedimentos desejáveis para a conformação de um estudante/cidadão adequado.

Nos textos analisados, foram encontrados enunciados que, dispostos lado a lado, formam um quadro de fragmentos que delineia a imagem rascunhada de um modelo de escola. Partindo dessa descrição propagada, pavimentamos um caminho de ideias no sentido de problematizar as verdades sobre educação escolar transmitidas pela mídia jornalística, bem como as convocações feitas por ela ante a problemática da gerência da escola.

Para efeito de análise, indicaremos os enunciados em três blocos separados. Tal procedimento, porém, consiste apenas em uma distinção de ênfase e de perspectiva para identificar diferentes domínios da investigação efetuada.

No cômputo geral das 449 matérias analisadas, entre entrevistas, reportagens, editoriais e artigos de opinião, encontramos uma constância na descrição da escola como instituição que deve ter a autonomia como método e a emancipação do estudante como objetivo, mas descrita como ineficaz em suas funções mais básicas. As ênfases 
aos problemas da e na escola são gritantes: desde o fim da década de 1990 até 2006, o discurso da ineficiência é o que predomina, juntamente com propostas de intervenção na gestão ou no projeto pedagógico. Questões como formação dos professores, avaliação, diferença entre educação pública e privada, e violência também compõem o quadro e entram como elementos coadjuvantes da paisagem constituída pelo discurso jornalístico sobre a escola. Tais proposições - a escola como instituição que possui a missão emancipadora do sujeito e sua declarada ineficácia em atender a todos nessa missão estão de tal maneira naturalizadas nas matérias jornalísticas que, mesmo quando o assunto em pauta não é nenhuma das duas, elas compõem o cenário dos textos.

Em geral, a "[...] falta de preparo, o desinteresse e a má remuneração dos professores" (FALCÃO, 1997) são apontados como um dos principais problemas da escola pública. Como consequência dessa falta de capacidade e empenho dos profissionais da área, a ineficácia da escola é apresentada por meio de estatísticas: diz-se, por exemplo, que “[...] 59, 9\% da população com mais de dez anos não completou o ensino fundamental” (GoIs, 2002), ou ainda, que "[...] um terço da população (31,4\%) com mais de dez anos de idade pode ser considerada analfabeta ou analfabeta funcional" (idem). Na descrição da escola, a paisagem pincelada corrobora com o aglomerado de dados informados, acarretando a naturalização e a generalização de que as escolas públicas do país são um espaço de "[...] 'transgressão e desordem' e viraram 'terra de ninguém'"(STRAuss, 2006).

Esse retrato da educação escolar é transmitido e retransmitido diariamente pelas páginas do jornal, a ponto de ter se tornado uma constatação naturalmente aceita. $\mathrm{O}$ discurso, longe de ser um elemento neutro, é um dos campos em que as relações de poder são privilegiadamente exercidas (FOUCAULT, 2004a). É nos artigos assinados por economistas, psicólogos, jornalistas e por mais uma diversa gama de especialistas, bem como nas reportagens sobre fatos ocorridos nas escolas, que forças de verdade são produzidas e legitimadas.

Utilizando o conjunto de racionalidades e prescrições presentes nos textos jornalísticos selecionados, apresentaremos três regularidades argumentativas utilizadas na composição de tais certezas sobre a escola: seu caráter indispensável, o alarido pela qualidade e a instigação de seu anacronismo. 


\subsubsection{Uma instituição indispensável}

Nos artigos analisados, a escola, mesmo sendo descrita como um espaço problemático, é apresentada como uma instituição que não pode ser negligenciada pela sociedade, pois possui a tarefa de produzir alunos/cidadãos. Esse caráter de indispensabilidade reforça a função da educação escolar como instrumento de produção de sujeitos autônomos - ideia que se encontra totalmente naturalizada e que é em parte fundada no pensamento de Immanuel Kant. Para o filósofo, a educação é a chave para a conquista da autonomia, esta compreendida como uma espécie de maioridade que transforma o indivíduo em um sujeito livre para fazer suas próprias escolhas (KANT, 1999).

Seguindo esse raciocínio, poder-se-ia afirmar que o sujeito autônomo pensa por si mesmo (KANT, 2005). Na medida em que, guiado pela razão, cria a si próprio, ele alcança uma maioridade, construindo sua liberdade e tendo como consequência a autorresponsabilização. A educação seria, portanto, a chave para a autonomia. Por meio dela, o sujeito conquistaria a disciplina, o conhecimento, a civilidade e a moral. Segundo Kant, esse processo de construção, capitaneado pela educação, duraria até o momento em que "o homem governe a si mesmo" (KANT, 1999, p.32).

Podemos inferir, então, que a ideia de educação escolar é transmitida e naturalizada como uma exigência da sociedade, pois é por meio dela que o sujeito vincula-se à razão, torna-se livre e, nesse mesmo processo, aprende a autogovernar-se. A educação é uma tecnologia que produz sujeitos civilizados, livres e responsáveis por suas escolhas, bem como compartilhantes de um rol de saberes e conhecimentos.

Assim, podemos compreender o caráter impreterível da educação enfatizado nas matérias jornalísticas como um movimento que impele à preservação e à sofisticação de uma série de práticas - discursivas e não discursivas - voltadas à formação de sujeitos autogovernáveis.

Para indicar essa indispensabilidade, são fornecidos alguns argumentos específicos, como a preocupação em adiantar o acesso à escola, pois “[...] pesquisas na área de educação e neurologia mostram que a aprendizagem da leitura e escrita deve começar muito mais cedo do que aos 7 anos de idade, como determina a Constituição" (RossETTI, 
1997). Dessa forma, as matérias afirmam ser benéfico que “[...] $\bigcirc$ tempo de escolaridade obrigatória do ensino fundamental aumente de oito para nove anos e o aluno deva ingressar na escola aos 6 anos" (BERNARDES, 1997b).

Além de argumentos a favor da antecipação do acesso à escola, também encontramos a insistência na universalização do atendimento escolar, obstinação na qual fica evidente a concepção kantiana, já que se considera que "[...] apenas a educação consegue dar aos indivíduos autonomia, capacidade de dirigir suas vidas, guiando-se pelo direito de optar" (FESTA, 1998). Argumenta-se, ainda, que estamos cada vez mais próximos

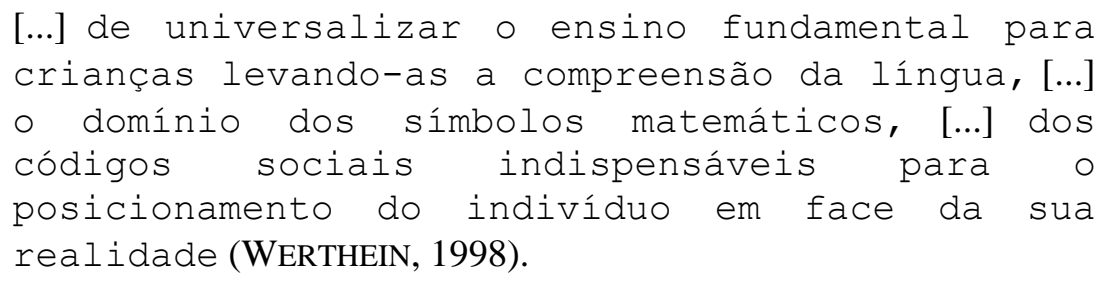

A preocupação de universalizar o acesso ao ensino fundamental deu-se principalmente entre 1996 e 2003; a partir de então, a meta volta-se ao ensino médio. Encontramos intenções de ações descritas como a necessidade de "[...] determinar a obrigatoriedade do ensino médio, ampliado para quatro anos" (BUARQUE, 2006), e inquietações de especialistas com essa faixa de ensino, pois "[...] o ensino médio funciona como um gargalo. A maioria dos jovens está matriculada no ensino fundamental, mas apenas 30\% passa para o ensino médio” (MEnA, 2005). São argumentos que, como vimos, intentam abarcar o maior número possível de sujeitos dentro dos muros da escola.

Somando-se aos argumentos apresentados sobre o caráter impreterível da escola, também é elencado um aumento da carga horária, visto que "[...] mais tempo na escola significa maior chance de o estudante ter um aprendizado efetivo, especialmente para aqueles provenientes de famílias com poucos recursos" (TEMPO, 2005). Como consequência desse afã educador, conjuga-se a apreensão com os índices de evasão - pois esta seria “[...] outro fator negativo da vida escolar no 
país. Apenas 54 de cada 100 alunos que entram no sistema de ensino chegam a concluir a oitava série" (VILlELA, 2006) - e também com a repetência, que é

[...] motivada, dentre outros fatores, pelo
desinteresse do aluno e pela necessidade de
contribuir para a renda familiar - o que tem
sido um dos maiores empecilhos para uma
integração mais qualificada na vida produtiva
(REFoRMA, 1997).

Percebemos, assim, uma forte atenção a qualquer fator que possa afastar os indivíduos da escola, pois o empenho em formar corpos dóceis e produtivos, junto à voracidade de constituir sujeitos autogovernáveis e autônomos, traz em seu âmago a ideia de salvação e uma concepção própria de educação. Os enunciados do jornal urdem um claro movimento de consolidação da escola como uma instituição mais abrangente, que inclua o máximo de sujeitos e que os conserve pelo maior tempo possível entre suas paredes.

\subsubsection{O clamor pela qualidade}

A descrição de uma educação de qualidade compreende uma escola que produza nos alunos as competências cognitivas necessárias e que seja, segundo Setubal (1997), "[...] norteada por princípios de justiça social, de inclusão e de cidadania". Na ausência de uma definição conclusiva sobre o que se refere à qualidade, dá-se destaque justamente à sua falta. Nesse processo, a procura por uma suposta qualidade, tema fácil e visível, inocula a falta como o sustentáculo da questão educacional, num deslocamento quase imperceptível. O que se discute não é a qualidade, mas a ideia da falta dela na associação direta com um modelo estabelecido $a$ priori.

Os artigos que versam sobre esse tema são encontrados regularmente no decorrer dos dez anos pesquisados. A falta de qualidade apresenta-se nas constatações de incompetência na formação dos alunos tanto na área das ciências exatas - em que "[...] apenas $2 \frac{\circ}{0}$ dos alunos da $8^{a}$ série têm competência em matemática [...] e cerca de 85\% dos estudantes se atrapalham 
com operações de multiplicação e divisão!" (BERNARDES, 1997a) -, como na língua portuguesa, pois, segundo Jorge (2002), os “[...] estudantes pobres que terminaram o ensino médio na rede pública, [...] quando submetidos a testes, fizeram uma leitura superficial e fragmentada dos textos". Alega-se, enfim, que a escassez de qualidade da nossa educação pode ser comprovada por meio de avaliações externas: segundo Gois (2002), “[...] os estudantes brasileiros ficaram em último lugar nas provas de leitura, matemática e ciências do Programa Internacional de Avaliação de Alunos". Desse modo, nas matérias jornalísticas, relata-se e ratifica-se estatisticamente uma carência que caracteriza a educação escolar como uma prática pouco eficiente à qual quase tudo faltaria.

Avaliações como o Pisa - acima referido -, a Prova e a Provinha Brasil, o SAEB, o ENEM e o IDEB, que foram implantadas a partir do começo da década de 1990, além de exames e rankings estaduais, como o paulista SARESP e o mineiro SIMAVE, fornecem os números para mensurar a suficiência e a insuficiência da educação de acordo com parâmetros bem específicos. As estatísticas produzidas por essas avaliações têm como função estabelecer um patamar de normalidade baseado nas regularidades encontradas. Além disso, ao especializarem-se e propalarem-se, elas “[...] permitem um controle mais rígido do sistema de ensino" (MORAES, 2003). Os dados qualificam e quantificam a educação; por exemplo, “[...] $\circ$ Saeb [exame do MEC que avalia a qualidade de ensinol mostra que 59\% das crianças na $4^{a}$ série não sabem ler e 52\% ainda não sabem fazer operações matemáticas simples" (GoIs, 2003). A constante é a falta da qualidade, e, para reforçar tal evidência, são utilizadas como exemplo as ditas boas escolas, apresentadas como exceções à regra do panorama educacional; trata-se de algumas poucas escolas públicas e de uma maioria de escolas privadas.

Há, nesse processo, um investimento na impotência e no alicerçamento da falta, fomentando uma miragem de algo que se poderia alcançar desde que fossem seguidas as coordenadas corretas, pois, conforme Rigout (1997),

[...] os resultados do Saresp mostram que os alunos das escolas públicas têm um ensino deficiente, mas há um grupo dessas escolas - a maioria no interior - que está formando alunos 
com desempenho semelhante ao de estudantes de boas escolas particulares.

Tais argumentos comprovariam que a educação de qualidade é plenamente possível, sendo que alguns já conseguiram alcançá-la.

A falta de qualidade descrita nos textos jornalísticos é o instrumento principal de um movimento propositivo que, ao indicar uma necessidade da instituição escolar, propõe uma ação para supri-la. Seguindo o raciocínio impresso nos artigos, se na educação falta qualidade, consequentemente uma maior atenção da sociedade sobre a escola pode e deve resolver o problema. São convocados investimentos em "[...] programas de gestão escolar" (TAKAHASHI, 2006); propõe-se a criação de uma força-tarefa para, segundo Tófoli (2005), “[...] melhorar a saúde dos alunos da rede"; apresenta-se a necessidade de "[...] desenvolver um trabalho de aproximação com os pais e a comunidade" (DIMENSTEIN, 1999); sugere-se o “[...] investimento na formação docente para a melhoria do ensino oferecido" (GoIs, 2000b), entre outras prescrições. Esse conjunto de ações indica, conforme o editorial de 9 de fevereiro de 1997, uma "[...] tarefa que depende não apenas de boas intenções dos governos, mas também da constante vigilância de pais e alunos em relação à qualidade dos serviços". Desta feita, a monitoração e a físcalização são eleitas como instrumentos de uma estratégia de controle e intervenção na escola.

Essa lógica discursiva, como vimos, tem por objetivo gerar uma tensão - a falta de uma educação que seja abrangente e eficiente - e conduzir a um enfrentamento - as injunções e as convocações dos especialistas representantes dos saberes validados -, criando assim um eixo que perpassa a discursividade jornalística analisada. A falta, eleita como um fator determinante da proposta de qualidade é, pois, o âmago da produção de uma verdade que define a escola como uma instituição inepta para suas funções básicas e dependente de monitoramento. Como soluções para tais problemas, são oferecidas algumas opções reguladas para a laboração de uma educação ideal. 


\subsubsection{A evocação do anacronismo}

Para encerrar a tríade descritiva da elaboração identitária da escola nos enunciados jornalísticos, temos as cogitações sobre o descompasso entre a prática pedagógica e um mundo em constante mutação. Acompanhando essas considerações, deparamos com propostas de modernização da escola por meio de um conjunto amplo de mudanças que apontam para novas formatações curriculares, com a incorporação de conteúdos ou disciplinas, e a reformulação dos métodos didáticos.

A partir das leituras dos artigos referentes a esse tema, podemos inicialmente inferir uma abordagem utilitarista em relação à função da escola. A alegada dissonância entre o que é ensinado na escola e os interesses e necessidades dos alunos é, desta feita, efeito da demanda econômica, da formação profissional e da gestação de trabalhadores com habilidades específicas para a atual configuração da sociedade, como descreve, o e Norberto Odebrecht (2006), empresário da área da construção civil:

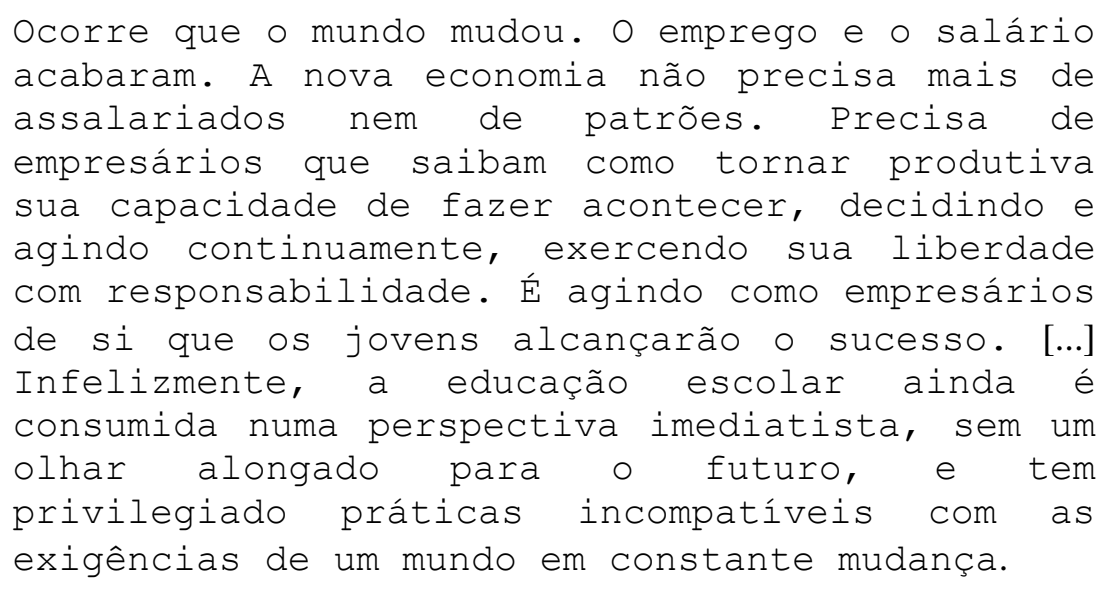

Contudo, prosseguindo na análise, damo-nos conta de que as inquietações de tais propostas são relativas à postura da escola, mas não apenas em termos utilitários. Esse movimento de desqualificação processa, de modo transversal, um corte que acaba impondo uma condição para que haja a superação de uma suposta desarmonia entre o que é ensinado e o que seria útil aos alunos. Podemos entender que nessas falas é evidenciada a seguinte questão: o que ensinar?

Deixando de lado as diversas lutas que se processam no entorno desse debate sobre o compromisso da escola, seja com a formação cultural, com a formação de recursos humanos ou com uma formação adequada para a superação dos problemas 
sociais, o que antevemos, aquém e além dessa contenda ideológica, é uma indagação insinuativa que se remete a impulsionar adaptações e/ou reelaborações dos currículos, já que estes estariam deslocados do contexto da sociedade atual. Trata-se de uma espécie de influxo para ajustar os currículos e o modo como são trabalhados, adaptando-os a uma lógica fragmentária, a uma emergência política.

Ao debruçarem-se sobre essa questão, as matérias jornalísticas lançam um olhar na direção da disciplina, do controle, da arquitetura curricular, das significações e usos do espaço e do tempo escolares, pois o currículo é expressão de sistemas de pensamento fundados em regras e padrões que ajudam a prover a individualidade. Por essa razão, o currículo regula não apenas o que é compreendido cognitivamente, mas como a cognição produz sensibilidades, disposições e consciência do mundo social (POPKEWITZ, 1994).

O descompasso é sinalizado no discurso jornalístico pelo viés da indiferença dos alunos em relação às aulas, pois

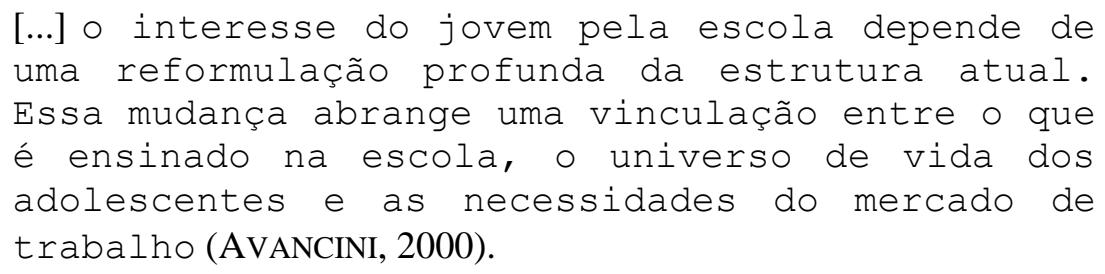

Relata-se que "a escola é chata. [...] o jovem tem razão
quando diz que não tem interesse em estudar. Ele não se
identifica com a escola porque ela não tem a cara dele" (AvANCINI, 2000). Para tornar a escola mais atrativa aos alunos, o ex-secretário da educação Gabriel Chalita propõe que "O aluno precisa ser mais seduzido para a educação. De repente, tudo foi evoluindo demais no mundo, e a educação é inflexível" (Pereira FILHO, 2002). Afirmações sobre a inutilidade dos conteúdos e as didáticas ultrapassadas tornam-se uma cantilena nos textos jornalísticos. A solução para essa questão? "É preciso mudar a escola internamente, por meio de um projeto pedagógico" (AvANCINI, 2000). E a receita é trocar os conteúdos, como explica Rubem Alves (2005): 


\begin{abstract}
Quando um professor tenta ensinar algo, ele tem de pressupor que aquilo é importante, não vai ser esquecido, vai fazer uma diferença na vida do seu aluno. [...] Dos 100\% de saberes que as escolas tentaram enfiar dentro de mim, só sobrariam uns 10\%. Você depositaria suas economias, mensalmente, num fundo de investimento, por 17 anos, se você soubesse que depois desse tempo você receberia só $10 \%$ do que você depositou? Alguns concluirão que a culpa é dos professores. Outros, que a culpa é dos alunos. Não creio que a culpa seja dos professores ou dos alunos. Acho mesmo é que a culpa é da carne que se põe na máquina: ela está estragada. As salsichas cheiram mal. O nariz as reprova. Se forem comidas, elas produzirão perturbações gástricas. O jeito é vomitá-las. Concluo: a performance das escolas melhorará se a carne estragada for substituída por uma carne que produz salsichas apetitosas.
\end{abstract}

O que nos chama a atenção é a eleição e a constância do tema, que abrange o descompasso entre, de um lado, o que é ensinado nas escolas e como isso é feito, e, de outro, o interesse e as necessidades do alunado. Há, portanto, um estímulo, um movimento que impele estratégias que, em conjunto com outras instâncias, produzam a reelaboração de currículos, métodos e posturas docentes. São enunciados que compõem um conjunto de procedimentos, conduzindo a determinado resultado.

Vimos que, no delineamento jornalístico, a escola é claramente definida como deficitária em relação a um modelo hipotético de educação, que ora assume a vestimenta do apregoado sucesso educacional de alguns países, tais como a Coréia do Sul

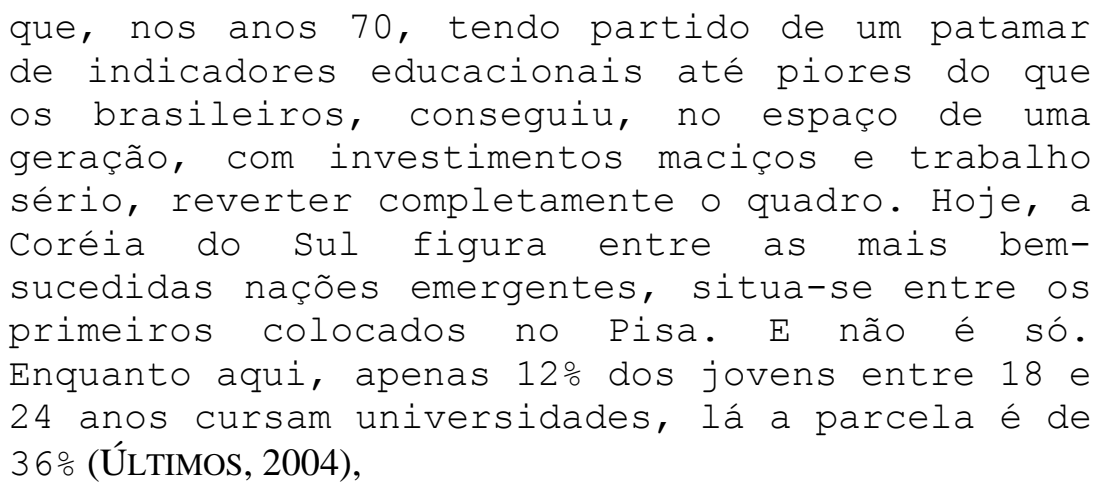

ora visita a paisagem de algumas escolas privadas consideradas de excelência, pois 


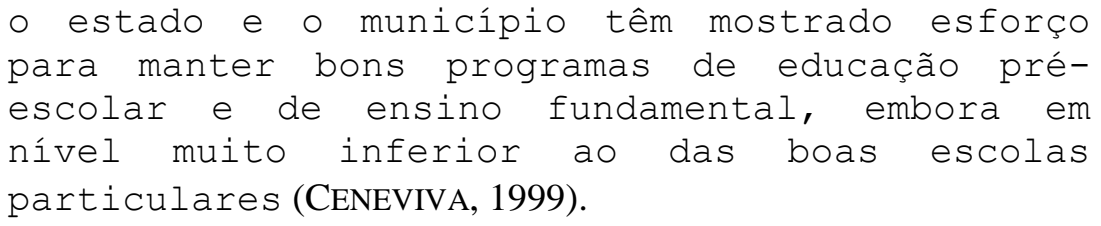

Essa escola descrita nas páginas do jornal é a afiguração de um ideal. A insistência de descrição e prescrição dos e nos assuntos escolares repousa em tópicos específicos - como educar, o que ensinar, de que modo fazer -, os quais atribuem ao processo educativo o sentido específico de formação, de constituição de um sujeito/cidadão regulado e, ao mesmo tempo, autônomo em suas decisões. Tal sentido está vinculado aos enunciados e processa-se por meio de racionalidades como: as estratégias discursivas - pesquisas e avaliações -, as autoridades a quem se concede a propriedade de dizer verdades sobre a escola e a valoração positiva ou negativa dos processos e profissionais envolvidos na área. As falas difundidas estão em conformidade com o discurso educacional, e este, por sua vez, com vários outros que se difundem em nossa época, o que faz com que esses dizeres sobre a escola consigam validar-se como verdadeiros, construindo o próprio objeto de que falam.

Seria a escola deficitária? Estariam os currículos defasados? Despontaria o caos com a ineficiência da educação escolar? Todas essas questões mostram-se inócuas, pois na escola não se aprendem apenas o que fazer e o que conhecer, também se aprendem disposições e sensibilidades em relação ao mundo que está ali sendo descrito, aprendem-se formas de falar, ouvir e raciocinar, formas pelas quais dizemos e entendemos a verdade sobre nós e sobre os outros. O que está em jogo é o gerenciamento da escola, pois ela é uma instituição que regula e disciplina sujeitos, é um campo no qual se combinam saberes, relações de poder e modos de subjetivação.

\section{3 - O receituário da salvação escolar}

No campo do discurso jornalístico relativo às descrições e aos relatos sobre a escola, encontramos um rol de prescrições. Nesse segmento, os artigos de opinião são majoritários, sendo assinados por uma gama considerável de entendidos, dentre eles, empresários, economistas, políticos e jornalistas. Entretanto, nas reportagens e entrevistas também nos defrontamos com recomendações, advertências e julgamentos 
feitos por experts no assunto, sendo estes, em sua maioria, professores e pesquisadores pertencentes à universidade e a centros de estudo e pesquisa.

As receitas para a redenção escolar não são muito variadas, podendo ser classificadas em duas categorias: a otimização e a integração. A opção por essa divisão deve-se ao fato de que tal classificação facilita a demonstração e a reflexão sobre os quadros narrativos. Nos textos dos artigos, porém, ambas as categorias aparecem entrelaçadas, formando um discurso uníssono.

Aqueles que prescrevem sempre apresentam alguma solução para normalizar a educação escolar de acordo com os parâmetros de determinada concepção de boa escola. A receita é muito simples:

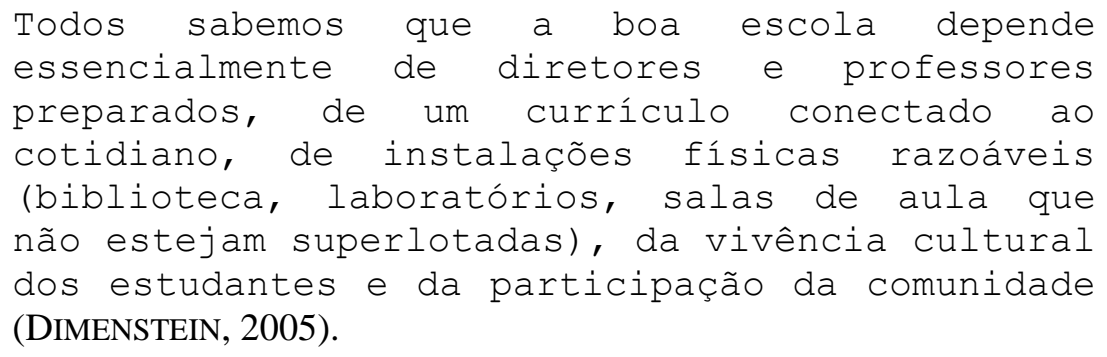

Nas sugestões das possíveis vias para um triunfo educacional, são indicados os limites e definidas as possibilidades, como em um jogo de cartas escolhidas no qual se indicam caminhos que obrigatoriamente levam a um único destino: uma educação específica, naturalizada como a melhor possível.

\subsubsection{Otimizando o campo escolar}

Sendo a educação definida pela falta e pelo descompasso, a proposta para solucionar essa equação negativa é o equacionamento das zonas nebulosas.

As soluções apresentadas nas páginas do jornal por políticos, pesquisadores e professores são bem parecidas umas com as outras e trilham duas vias: a formação e o investimento. Nesses caminhos prescritos, são vários os objetos oferecidos como focos de intervenção: o professor, o espaço físico da escola, o método e o conteúdo. É interessante a dicotomia apresentada pelas várias opiniões oferecias pelo jornal. Por exemplo, no caso da análise dos professores, algumas vezes estes são classificados como vítimas de um sistema, pois "[...] não são mal remunerados, são 
pessimamente remunerados, e não têm nenhum estímulo à sua formação, muito menos para realizar um bom 'gerenciamento'" (GENRO, 2005); outras vezes, são apresentados como algozes da dita educação de qualidade, já que o "[...] professor é despreparado. Mesmo com acesso ao melhor conteúdo e sofisticada infra-estrutura, ele pouco melhora a produtividade em sala de aula" (DIMENSTEIN, 2000). Para solucionar o problema docente, temos a questão da formação - inicial e continuada -, com a sugestão de “[...] cursos de formação para professores em parceria com universidades, pois é preciso recuperar a auto-estima do professor e isso passa pela formação continuada" (ARANTES, 1997), e da remuneração, como comenta o professor Alfredo Bosi (1997):

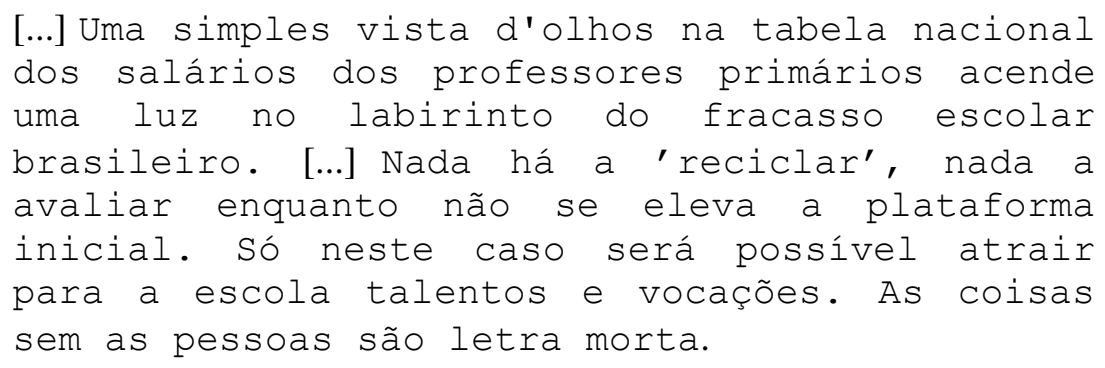

Reforçando a dicotomia básica que, aparentemente, diversifica as opiniões apresentadas pelo jornal, pois abrange as diversas hipóteses possíveis, encontramos a opinião de um articulista - Gustavo Ioschpe (2005) - que em nada se parece com a anterior:

[...] A maioria dos estudos sobre a área indica, para grande surpresa, que aqueles mecanismos comumente associados à melhoria da educação e empregados pelo nosso governo, como melhor remuneração ao professor e menos alunos por sala de aula, têm resultados majoritariamente insignificantes.

Dentro de um mesmo discurso podemos encontrar não apenas regularidade e consenso, mas também oposição e contradição. Trata-se de uma produção argumentativa que, ao considerar uma posição, transita para outra oposta, contraditória 
ou diferente, propondo tessituras que relacionam o fato com a verdade sem estabelecer um caminho único, mas uma estrada com múltiplas direções.

Superando essas divergências que compõem um jogo, invalidam e/ou legitimam proposições, o tema da formação dos professores é unanimidade. Em praticamente todos os artigos que tratam do assunto, atribuem-se a essa formação poderes de salvação ou de danação: um estudo da Unesco, por exemplo, "mostra o Brasil como campeão da América Latina em repetência escolar [...] e o Ministério da Educação atribuiu os péssimos resultados obtidos à má formação dos professores (ETERNA, 2002). Tal postura evoca uma segunda característica da questão, que é a urgência no investimento da formação continuada desses profissionais, como no caso dos

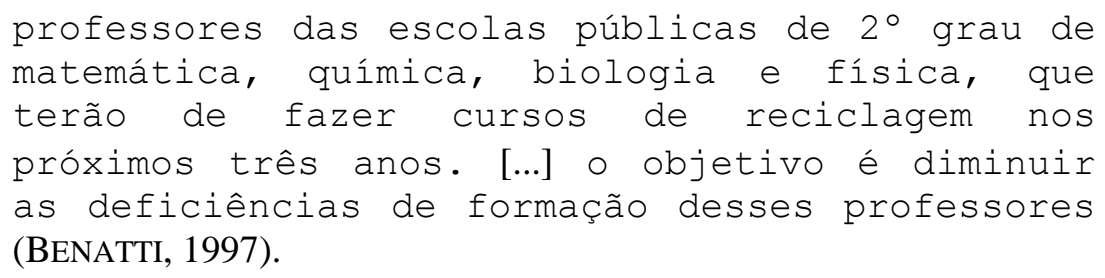

O discurso sobre a prática da formação, seja a inicial ou a continuada, não apenas sugere uma atividade ao sujeito docente, mas faz parte de uma estratégia por meio da qual circulam dizeres e saberes, inserindo-o num jogo em que sua participação ativa convive com "a existência objetiva e material de certas regras às quais o sujeito está submetido desde o momento em que pratica o discurso" (LECOURT apud VEIGANeto, 2004, p.52). Em outros termos, trata-se de um complexo de enunciados no interior do qual o sujeito confronta-se com o que ele pode saber, o que lhe é autorizado a ver e a dizer sobre uma realidade em determinado contexto, enfronhando-se na lógica do discurso que constrói o objeto do qual fala. Não estamos nos referindo aqui a uma dominação de um sujeito acéfalo, mas justamente à interação em jogos de verdade em que o sujeito constitui-se com margens de liberdade.

Em cada relação que estabelece com esse discurso que atua como verdadeiro e é validado pelos saberes da área, o sujeito posiciona-se de determinada forma. Sendo assim, diferentes sujeitos são formados, conforme a vinculação que se estabelece com o jogo de verdade posto. A valorizada e requerida formação constitui-se num campo de práticas discursivas que posicionam os professores num processo cíclico interminável 
de treinamento e estudos, imerso em práticas discursivas que utilizam e ultrapassam a questão dos conteúdos, propondo não só o aprimoramento técnico de um docente, mas a qualificação moral de um sujeito escolar.

Nas páginas do jornal, simultaneamente à formação dos professores, propõe-se uma atenção especial à função dos diretores, acrescentando mais um item ao receituário relativo à melhoria da instituição escolar. A frequência das reflexões sobre esses profissionais, apresentados como gestores, é menor do que a das matérias referentes aos professores, mas apresenta uma característica estratégica: é na capacitação ou no treinamento, como afirmam alguns dos textos, que se encontra uma das chaves para alcançar a almejada qualidade, pois "sem bons diretores, não existem boas escolas. O bom gestor é um empreendedor social, capaz de motivar os professores, a família e a comunidade" (DiMENSTEIN, 2004). O gestor é uma peça fundamental para a eficácia da escola, já que "sem diretores preparados, esqueça: não existe educação que prospere. É como imaginar que uma empresa possa sobreviver sem um executivo qualificado" (DimensteIn, 2004). O investimento, pois, deve ser da altura desse componente essencial e, para tanto, "nove bancos estrangeiros que atuam no Brasil vão investir, nos próximos três anos, R\$ 1,25 milhão para ensinar diretores de escolas públicas a gerenciar melhor seus recursos"(GoIs, 2000a).

A necessidade constante de aperfeiçoamento dos diretores e professores é um dos principais tons das matérias jornalísticas. Encontramos aqui o ritmo de uma modulação permanente (DELEUZE, 1992), abalizada por contornos de movimento constante, detectados e agregados aos discursos que os transformam em dados compatíveis com a transmissão de enunciados, os quais, por sua vez, compõem os próprios discursos. Temos, enfim, uma rede de enunciações que se conformam num entrelaçado, compondo um conjunto de ações, fatos e ideias, e criando uma sucessão de fenômenos, entre os quais se podem estabelecer vínculos, conexões e relações, em uma cadeia de inteligibilidade na qual a grande maioria dos sujeitos escolares opera.

A destinação dos recursos financeiros é abordada nos jornais, que prescrevem a melhor maneira de utilizá-los. Novamente, numa ação argumentativa, são apresentadas várias correntes que defendem diferentes modos para a aplicação dos recursos públicos destinados à educação. Como já vimos, alguns apoiam o incremento dos salários dos 
profissionais da área; outros preferem a aplicação nas estruturas físicas das escolas, pois, apesar de a infraestrutura variar conforme a região do país, ela é, de modo geral, insuficiente, visto que

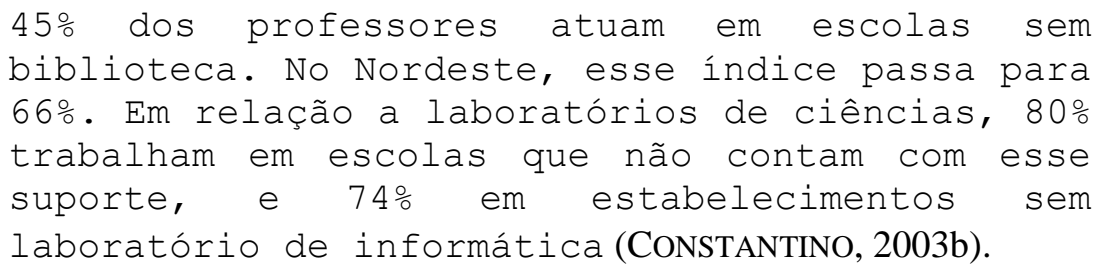

O currículo escolar também é contemplado com prescrições salvacionistas. Já fizemos referência aqui às queixas sobre o seu descompasso diante das exigências de uma sociedade em constante mutação. Apresentaremos, agora, quais são as correções aconselhadas e as soluções receitadas.

Uma proposta bem recorrente é o acréscimo de conteúdos. Há relatos sobre a importância de ensinar questões de saúde, como no caso da "AIDS, que veio para ficar e deve ser submetida não a uma campanha, mas a uma educação continuada e tem de fazer parte do currículo escolar" (IIzUKA, 1997). Ou sobre iniciativas de conscientização, pois o "ambiente entrou no currículo das escolas públicas do país" (FrAnÇA, 2001), Promove-se, ainda, uma educação não racista e mais abrangente: os currículos "deverão contemplar o estudo da história da África e dos africanos, a luta dos negros no Brasil, a cultura negra brasileira e o negro na formação da sociedade nacional" (Cosso, 2003). Também outras sugestões de conteúdos foram descritas, como a de abordar a saúde mental nas salas de aula, ideia que o

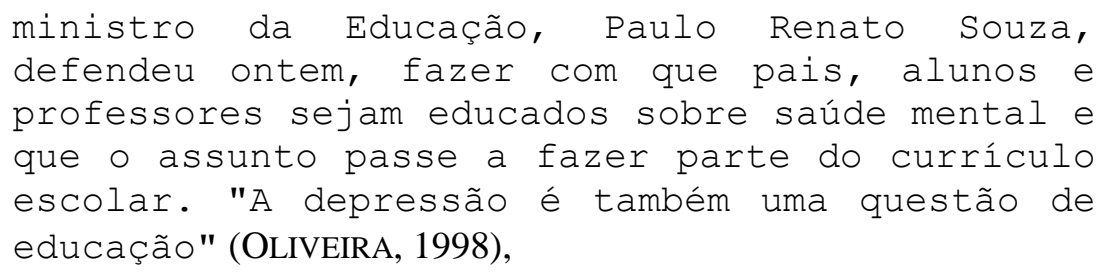

e a de contemplar a educação financeira, pois esta é "importante para a vida em sociedade e já é dada por algumas escolas" (NAZARETH, 1999). 
Como vimos, os conteúdos escolares são considerados no discurso jornalístico como um campo ilimitado, aberto a todas as possíveis inserções de modo a suprir as deficiências para a formação de um sujeito ideal. Seguindo esse caminho, visualizamos tal espaço como um campo de luta em torno da construção e da difusão de significados sobre o mundo social. As sugestões de novos conteúdos visam à produção de sentido, pois atuam no currículo: uma zona de produtividade (SILVA, 2003) na qual operam relações de poder e conjugam-se processos de subjetivação. As práticas discursivas não são pura e simplesmente modos de fabricação de discursos; elas ganham corpo em procedimentos técnicos, em instituições, em esquemas de comportamento, em tipos de transmissão e difusão, e em formas pedagógicas.

A estrutura física das escolas também é mencionada como um fator preocupante diante da intenção de produzir uma educação de boa qualidade. Encontramos, entretanto, argumentações em que se garante que as condições materiais e de instalações pouco interferem na excelência do processo de ensino e aprendizado.

[...] os extraordinários resultados nas avaliações
internacionais obtidos pelos estudantes da
Coréia, Taiwan e Cuba, significativamente
superiores aos franceses, ingleses e
americanos, demonstram de forma inequívoca que
educação de qualidade tem muito pouco a ver com
instalações físicas e tudo a ver com a
qualidade e a motivação dos professores (AGUIAR,
2003).

Tal divergência de opiniões transmite a ideia de uma ampla abordagem na qual todas as vozes são ouvidas; no debate, cria-se um forte jogo polêmico, com falas persuasivas que disputam a eficácia de seus argumentos.

Esse jogo desfaz-se, porém, na análise do conjunto de artigos que abordam o assunto, pois o entrelace das asserções propõe vários caminhos que culminam no mesmo destino: seja pela defesa da priorização das verbas para incrementar as condições materiais da escola, seja pela valorização dos recursos humanos, a escola é posta como uma das mais importantes instituições deste tempo, e sua permanência como lugar privilegiado dos saberes e da formação de cidadãos é indiscutível. O que varia é o modo de acessá-la - por cima, por baixo, pela esquerda ou pela direita. Temos, portanto, uma só verdade: a instituição escolar como a melhor via para promover as 
aptidões e habilidades dos indivíduos, levando-os a uma plena realização e constituindo, assim, pessoas esclarecidas, críticas, autônomas e atuantes para compor a sociedade.

Nas abordagens sobre as instalações escolares, a comparação entre as escolas privadas e públicas é constante. Nesse caso, há, invariavelmente, uma exaltação das condições das primeiras em detrimento das últimas, principalmente em referência às

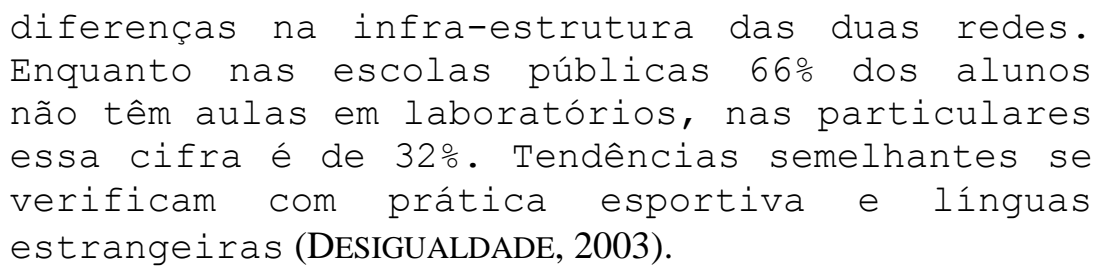

A solução: mais investimento.

Outra relação sugerida é entre a falta de estrutura e a violência presente nas escolas, pleiteando um movimento de embelezamento das escolas a fim de aprimorar as relações e ações que nelas se processam.

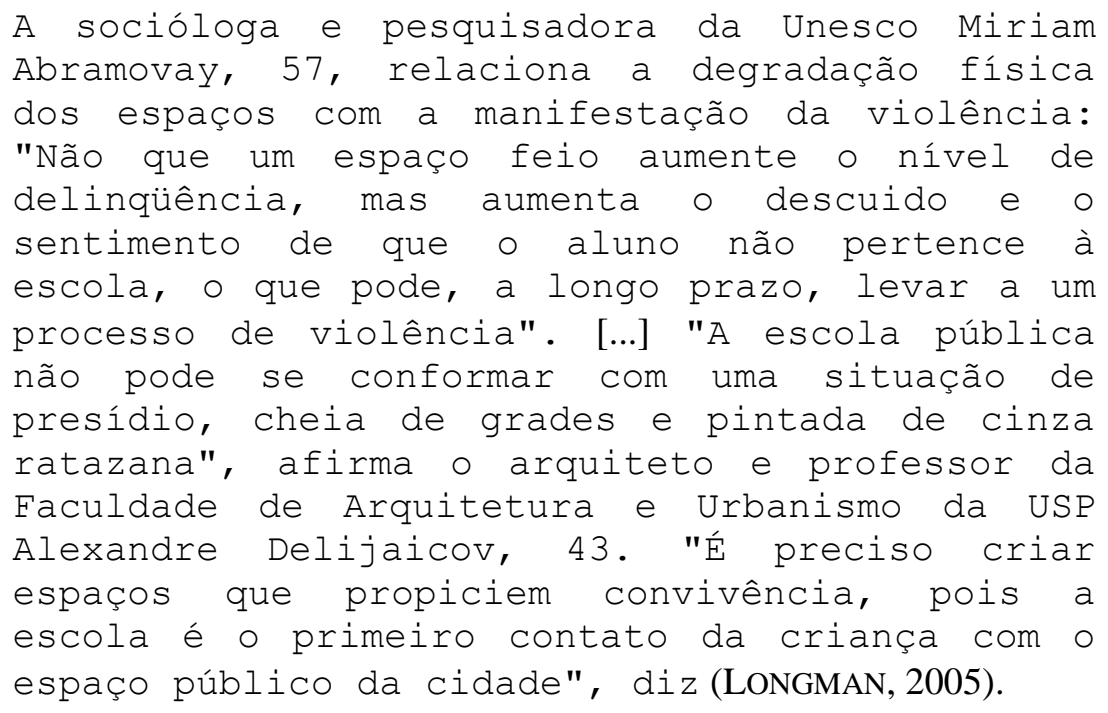

O que se avia nesse raciocínio é a substituição de uma vigilância repressora por uma disciplinadora. A preocupação com a arquitetura traduz essa lógica: quanto maior a identificação do aluno com o espaço e quanto maior seu convívio com ambientes abertos e de coexistência, maior é a autodisciplina e mais fácil é o ordenamento.

Os remédios prescritos nos artigos jornalísticos descrevem, por meio de um processo guiado por cálculos de probabilidade sustentados por pesquisas acadêmicas, as condições consideradas necessárias para que se alcance uma eficiência educacional 
dentro de um ideal bem concreto. Com essa descrição, os enunciadores de tais soluções visam à exaltação dos fatores considerados precários e ao equilíbrio das possíveis intervenções, sempre atribuindo ao Estado uma parcela de responsabilidade, mas convocando as organizações da sociedade civil para executar sua parte. Frisar defeitos e oferecer conceitos sobre professores, diretores, currículo e infraestrutura das escolas, funcionam, assim, como estratégias de prevenção e organização do quadro educacional.

\subsubsection{Comunidade e escola: uma integração almejada}

Outro ponto de intervenção tornado explícito nos discursos da imprensa sobre a escola caminha na direção de integrá-la à comunidade e de convocar a participação dos pais na educação escolar de seus filhos. Encontramos uma regularidade significativa nas matérias que indicam e louvam as iniciativas de abertura das escolas para a comunidade, exaltando essa relação como saudável e necessária para o sucesso da educação. Nesses textos, o respaldo acadêmico tem o propósito de fundamentar tal ideia, de comprová-la, como se pode observar neste exemplo:

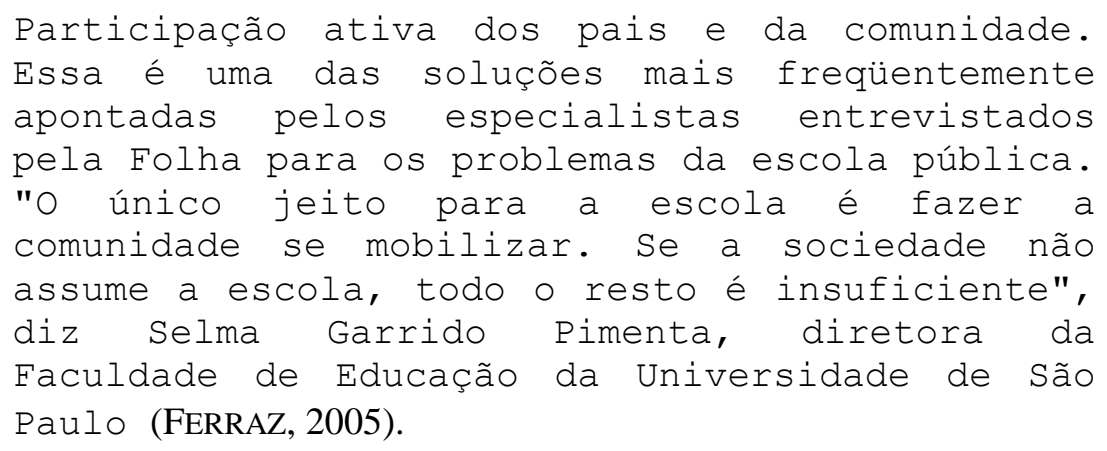

Uma característica peculiar dessa construção é a de que a escola pública é amplamente convocada a abrir-se à comunidade, ao passo que não encontramos nenhuma matéria que sugerisse o mesmo movimento para as escolas privadas. Nesse caso, a convocação dá-se ao voluntarismo educativo, numa injunção à formação de um país mais justo socialmente. Notamos que a preocupação, no caso das escolas privadas, não é a melhoria da educação, mas o condicionamento a um comportamento socialmente valorizado, como nos explica a empresária Milu Villela (2005b):

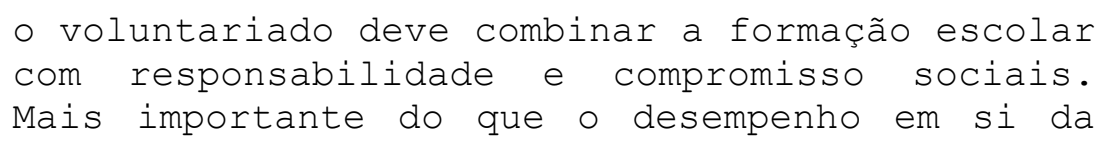


ação voluntária é a sua articulação com os saberes escolares.

Isso nos leva a pensar que o que é considerado fundamental não é o gesto de ajudar, mas uma correlação entre o ato voluntário e os discursos escolares, sintetizando a prescrição: uma prática não discursiva associada a uma prática discursiva que opera tanto nos voluntários como nos desvalidos.

Voltando à questão da integração da escola com a comunidade, as matérias indicam que esse movimento baseia-se em três objetivos fundamentais: a melhoria do ensino, o reforço da segurança e o oferecimento à comunidade de um espaço alternativo e apto ao lazer e à cultura. Mescladas em intenção, as proposições das matérias almejam o espaço escolar como uma grande massa educacional que atue para além de seus muros, afetando todos aqueles que, de um modo ou de outro, dela compartilham.

O processo de abertura das escolas tem um duplo viés. Primeiro, responsabilizar a sociedade como um todo pela educação de seus cidadãos, estabelecendo "a participação da comunidade na gestão de todas as unidades de ensino" (ATHIAS, 2001), num movimento que abre os portões da escola para mais uma prática de regulação: a presença de pais e interessados na gestão do ambiente escolar dispõe diferentes olhares sobre a tarefa educativa, pois "escola pública sem cobrança dos pais é como um produto livre das leis de defesa do consumidor" (DIMENSTEIN, 2006). Segundo, convocar a participação dos pais e da comunidade, trazendo-os para dentro de seus muros. Assim, outros sujeitos são chamados a participar das atividades propostas para a utilização da escola como espaço cultural e esportivo, atividades nas quais são difundidos modos saudáveis e adequados de vida, aumentando a possibilidade de alcance de suas práticas corretivas a esses outros sujeitos, como relata uma reportagem:

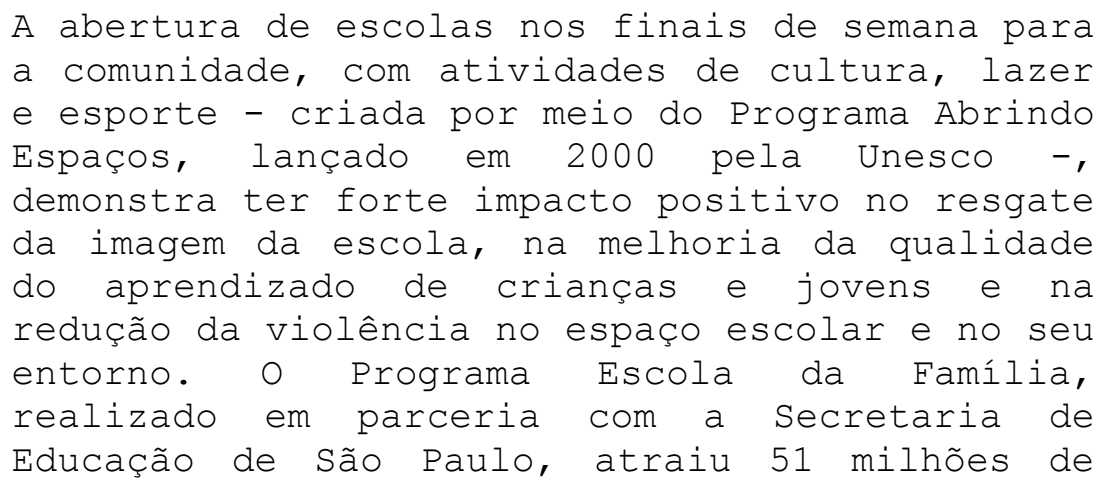




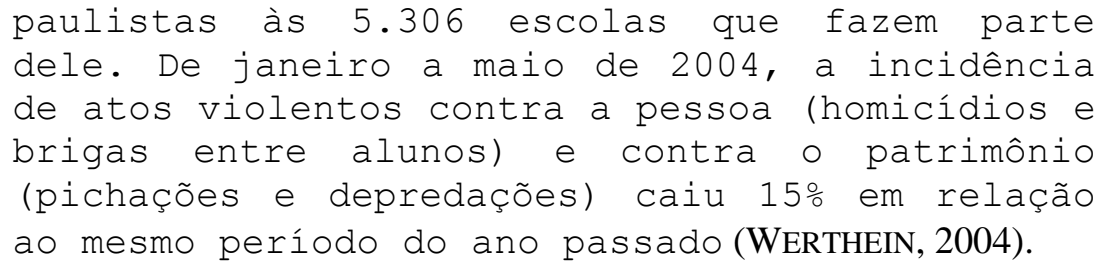

A definição de comunidade apresentada nos textos é um tanto imprecisa, sendo que apenas algumas de suas indicações permitem-nos inferir que o termo é utilizado em referência ao conjunto de integrantes da instituição escolar (alunos, professores, gestores e funcionários) somado aos pais, ex-alunos e, como algumas vezes mencionado, comerciantes situados próximos ao estabelecimento.

Radicalizando a argumentação sobre o que os artigos chamam de comunidade, buscamos auxílio nos pensamentos de Jean-Luc Nancy, autor apresentado em texto de Peter Pál Pelbart (2003). Para o filósofo francês, a noção de comunidade usualmente aceita, que expressa uma nostálgica ideia de comunhão e unidade (comum/unidade), nunca existiu. Nancy afirma que a comunidade só é pensável como negação da homogeneidade, sendo necessariamente heterogenia, pluralidade. $\mathrm{O}$ desejo de uma ligação comprometida entre iguais, a ânsia de copertencimento, de fusão entre irmanados que partilham gostos, interesses e sentimentos, resultaria em exemplos de totalitarismo, como no caso do nazismo.

Os enunciados sobre a comunidade e seu envolvimento nos projetos educativos são propostas de condução a uma essência de unidade que parece não se sustentar. Nesse jogo, processa-se uma prática no intuito de agregar, em torno de valores e ideais de unificação, sujeitos dispersos. Há a convocação a uma fusão comunial em que se produzem dois apelos: o primeiro diz respeito à constituição de uma organização social específica; o outro remete a uma invocação à dignidade, à vida, ao bem-estar. Reunir escola e comunidade, segundo essa perspectiva, seria melhorar a vida, partilhar valores. Tal convocação opera como a predição de uma razão comum, garantindo, assim, a fixação de um tipo de sujeito cuja existência está vinculada à possibilidade desse exercício de comunhão.

Os artigos jornalísticos, por meio da obstinação em integrar e otimizar, compõem um receituário para a salvação de uma educação claudicante e pouco produtiva. Esse rol de recomendações é constituído por uma rede de informações e opiniões de especialistas - seja o jornalista messiânico, seja o empresário imbuído de 
uma ética funcionalista - que prescrevem condutas em nome de um bem-estar social e individual.

Aos leitores heterogêneos é oferecida a possibilidade de uma reflexão sobre seus próprios papéis e sobre a conjuntura geral do panorama escolar. À escola e seus participantes, diretos e indiretos, o recado é dado em determinada direção: a eterna precariedade da educação escolar pública. Há um apelo à atenção de cada um, e ele estrutura-se na busca de uma verdade que, apesar de já enunciada, precisa ser constantemente reproduzida a fim de que se naturalize sempre e mais.

O discurso sobre a educação nas páginas do jornal, suas críticas positivas e negativas, bem como suas prescrições, constituem uma forma complexa, eficiente e econômica de conduzir condutas, receitando os melhores remédios para os supostos males da escola e oferecendo o caminho para vidas plenas e emancipadas, de cidadãos responsáveis e felizes. 


\section{IV - FECHAMENTO DA EDIÇÃO: \\ OS DESDOBRAMENTOS DO DISCURSO JORNALÍSTICO SOBRE EDUCAÇÃO}

$\mathrm{Na}$ intrincada malha do discurso jornalístico sobre a educação escolar, vemos o funcionamento do poder em rede, em cadeia. Propagam-se modos de vida, por meio de etapas e métodos para alcançar uma existência plena, autônoma e responsável. A civilidade, a produtividade e a racionalidade estão em pauta quando se elege um ideal de educação, bem como quando se deprecia uma realidade educacional narrada por prospecções negativizadas.

Ao nomear faltas e incorreções da educação, os enunciados jornalísticos imprimem uma organização ao campo, independentemente de tal campo ter ou não existência prévia à própria nomeação. Nesse processo estão envolvidos elementos currículos, formação etc. - que, ao serem tomados como componentes de um conjunto de ineficiência, forçam a abertura de espaços de controle.

Quando se prescrevem e receitam formas de eliminar adversidades e de superar dificuldades, franqueia-se uma abertura para a supervisão e a intervenção, as quais são apresentadas como uma demanda social. Está, então, criado um campo de regulação fundamentado na evocação e no convencimento sobre certo tipo de vida para certo tipo de sujeito - ambos asseverados como os mais plenos possíveis.

\section{1 - O discurso do jornal e o governo dos viventes}

A série de elementos que a mídia apresenta como constituindo a educação escolar fundamenta um regime de verdade que, no interior de uma rede de práticas, serve como mais um expediente para o controle das condutas escolares.

Vemos o discurso jornalístico sobre educação escolar atuando como um dos elementos de governo das ações, intenções e quereres da população. Desse modo, o discurso sobre educação é utilizado como um regulador importante da estabilidade e do desenvolvimento da vida, movimento que mostra como a regulação desta é indispensável nas estratégias e práticas de governo das populações.

Tais práticas que têm como alvo a população permitem analisar as relações de poder que se operam nas sociedades. Para Foucault, o "poder deve ser analisado como 
algo que circula, ou melhor, que funciona em cadeia" (2006c, p.183). O poder não é, portanto, algo de que se toma posse, mas está presente em relações e processos que atravessam sujeitos e que deles derivam, funcionando em rede. Além disso, o sujeito não é um alvo passivo dessas relações de poder, mas um de seus efeitos, sendo que ele também as exerce. As teias que se formam em tais relações constituem-se de estratégias e táticas engendradas em discursos e ações. Dito de outro modo, trata-se de uma ação que se dirige a outra ação, de uma força que faz o outro agir.

Como vimos, a educação escolar está intrinsecamente atada à formação do que entendemos como um indivíduo autônomo, racional e livre. Esse processo dá-se por meio das práticas disciplinares que acontecem primordialmente, mas não apenas, dentro da instituição escolar. Por conseguinte, alega-se a imprescindibilidade desta para a formação de cidadãos. É nela que se opera uma disciplina sofisticada: um conjunto de controle das atividades, dos espaços e dos tempos focando o aluno como o centro das atenções pedagógicas e formativas, oferecendo-lhe uma liberdade orientada e mediada.

Essas tecnologias, que constituem o sujeito-aluno preparando-o para uma sociedade de indivíduos, constroem uma realidade, a qual é comentada, relatada, descrita e também reproduzida e modelada pelos meios de comunicação de massa por intermédio de um discurso autorizado e legitimado. Processa-se, assim, um movimento de veridicção: uma realidade é constituída, fatos sobre ela são narrados, pesquisas sobre o que lá acontecem são apresentadas, legitimando o verdadeiro e combatendo as falsidades. Esse discurso circular volta à escola e é reconhecido por seus integrantes, criando uma zona de inteligibilidade em que, ao falar de escola, de educação básica pública e outras temas, imediatamente há o reconhecimento das características e necessidades da instituição arquitetadas nesse jogo.

Apesar de compor uma rede - escola, mídia, academia e outras instituições -, o papel da imprensa é também a vigilância e o controle sobre a educação escolar, tanto que seu discurso baseia-se em cobranças e recomendações para melhorias e aperfeiçoamentos. Os artigos, sejam eles descritivos, opinativos ou prescritivos, operam como práticas de controle que consistem em ordenar possibilidades, estruturando um eventual campo de ação. Esse exercício é da ordem do governo, sendo que tal conceito não se refere especificamente às estruturas políticas e à gestão do Estado, mas ao sentido em que a palavra era empregada no século XVI, quando designava a maneira de dirigir a conduta dos indivíduos e dos grupos: governo das crianças, das almas, das 
comunidades, das famílias, dos doentes (FouCAULT, 1995). O governo pode ser definido como uma maneira considerada correta de dispor cada uma das coisas a serem governadas para conduzi-las a um objetivo adequado (FOUCAULT, 2008c).

Essa arte de governar foi denominada por Foucault de governamentalidade. Trata-se de uma racionalidade de governo centrada nas problemáticas da população, da economia e da segurança. Sua tecnologia multiforme age de maneira abrangente e apurada, articulando-se em uma consonância de saberes e incidindo sobre os sujeitos de forma a regular, marcar e normalizar. É por meio de "processos de governamentalização que se perfaz um duplo golpe: a regulamentação das condições de vida das populações e a disciplinarização da existência de seus componentes individuais" (AQUINO; RIBEIRO, 2009, p.60-61).

Governamentalidade, assim, diz respeito diretamente à condução da conduta de um grupo de indivíduos, em dimensões capilares. Ela
incide sobre os corpos individuais e coletivos regulando, marcando, normalizando e individualizando; induz efeitos de subjetividade, produz subjetivações; concerne à vida dos indivíduos, dirige-se à sua conduta, envolve técnicas de governo de si mesmo (PRADO FILHO, 2006, p.19).

Numa tessitura complexa, os escritos jornalísticos operam em consonância com as produções acadêmicas, os saberes dos especialistas - também fundamentados em conhecimentos produzidos em centros de pesquisas e universidades -, as injunções econômicas e políticas, enfim, práticas discursivas e não discursivas que formam uma urdidura orientada por esse discurso sobre a escola, produzindo verdades que alimentam e governam a própria instituição.

A utilização da falta como principal argumento discursivo das matérias da imprensa evidencia o que acabamos de expor. A escola é definida a partir de sua deficiência, de seu desajuste a certa concepção de educação. A falta sempre se dá em relação a algo que deve ser, a um ideal, estabelecendo uma distância a ser percorrida para chegar à plenitude. Pois bem, uma instituição deficiente precisa de assistência e intervenção; abre-se assim o caminho para regulações e controles, induzindo e embasando políticas públicas dirigidas à educação. 
Falamos aqui de um poder que funciona em cadeia, que não é repressivo, mas produtivo e transformador. Por meio de estratégias, ele cria campos de conhecimentos e, ao produzir diferentes versões sobre a realidade, também produz essa própria realidade. Analisando a política da verdade conduzida pela imprensa, podemos afirmar que ela está centrada na reafirmação do discurso cientificizado tão utilizado em suas falas, principalmente quando se refere ao anacronismo e sua influência direta na obsolescência dos currículos. O ato de examinar, denunciar e prescrever ações e correções ao instrumento de programa dos conhecimentos escolares demonstra uma tentativa de gerenciamento. Ajuíza-se não só o que deve ser dito e ensinado na escola, como também o que deve ser silenciado, apontando assim para a inclusão de novos conceitos e para a diversificação dos eixos de aprendizagem. Os especialistas, maiores redatores sobre o assunto, ajudam a omitir os saberes que não fazem parte de um discurso autorizado e reforçam os que fazem.

Os currículos escolares estão diretamente ligados aos saberes e à individualização dos alunos, sendo por meio deles que capacidades e habilidades são valorizadas ou desvalorizadas. Podemos dizer, por exemplo, que há 50 anos um bom aluno teria a memorização como habilidade enaltecida; desde os anos 80, porém, o bom aluno é aquele que consegue estabelecer relações entre dados disponíveis, e a memorização foi execrada das práticas escolares. Logicamente que o tipo de sujeito formado para a memorização é bem diferente daquele que faz relações e comparações, ou seja, o currículo e seus dispositivos avaliadores são práticas que colaboram para a preparação dos sujeitos necessários à sociedade. A título de ilustração, para demonstrar como tais práticas são maleáveis e adaptáveis às necessidades econômicas e políticas, recentemente foi publicado um artigo na Folha de São Paulo em que o articulista relata o trabalho de um pesquisador de uma universidade americana, mostrando que alunos que estudam pelo método da memorização aprendem mais do que os que utilizam outras práticas (SCHWARTSMAN, 2010). Esse caso exemplifica como as verdades educacionais são provisórias, como os estudos acadêmicos, geralmente legitimadores da verdade, são maleáveis e adaptáveis.

A triangulação entre sujeito, verdade e poder está sedimentada em como o sujeito relaciona-se com as verdades que encontra à sua frente. Pesquisando sobre esse tema, Foucault descreveu práticas estabelecidas nos séculos III e IV pelo cristianismo. Tais práticas eram fundadas em estratégias de condução e direcionamento dos homens 
por meio de técnicas de si que resultam em processos de subjetivação nos quais os homens conhecem-se e aceitam verdades. A essa técnica de governo o autor denominou poder pastoral: prática que agia sobre a identidade das pessoas, procurando sujeitá-las, ao impor uma lei de verdade pela qual a identidade deveria passar a ser guiada.

A figura fundamental dessa estratégia de poder é a figura do pastor e seu papel de guiar e fazer o bem. Ele deve estar informado das necessidades materiais e espirituais de cada membro do grupo, e sua função fundamental é fazer o exame e o direcionamento da consciência de seu rebanho. O exame de consciência faz com que os indivíduos entreguem toda sua vida para o pastor, e a direção da consciência significa que cada um deve deixar-se conduzir. O poder pastoral, portanto, é definido por um bem-fazer com o intuito de dirigir todo o grupo, cuidando e preocupando-se com cada uma de suas almas. Assim, tal modalidade de poder ocasiona uma condução cotidiana e a gestão detalhista dessas vidas. É uma arte de conduzir, de guiar os homens, atingindoos tanto coletiva quanto individualmente.

Tal modalidade de poder foi absorvida pelo Estado laico e a função pastoral dispersou-se. Nos dias de hoje, o governo da alma é exercido por uma gama de profissionais que pastoram os indivíduos, desde os pregadores de autoajuda, passando pelos profissionais psi até os especialistas dos meios de comunicação, entre outros.

O governo da alma praticado pelos veículos de comunicação configura-se de modo diferente do modelo pastoral dos séculos passados. Os pastores modernos agem sobre escolhas, desejos e condutas do sujeito moderno, atuando por meio da persuasão inseparável das verdades por eles apresentadas e pela sedução da vida que oferecem (Rose, 1998).

No caso da educação, a ação processa-se, "sobretudo, por meio de um incansável trabalho de inculcação de ideias transcendentes que, não obstante sua relevância política lato sensu, serão repetidas à exaustão, reduzindo-se a slogans" (AQUINO, 2011). Podemos perceber claramente esse jogo nos artigos jornalísticos, quando, por exemplo, são apresentados enunciados sobre os professores e sua formação.

No que se refere a esse tema, as falas jornalísticas frisam amiúde a péssima formação dos docentes da escola pública, apontada muitas vezes como uma das causas principais do fracasso da educação. Selecionar o assunto como apto a fazer parte das pautas educativas demonstra mais um exercício de regulação. Entre as conseqüências, 
verificamos a abertura de espaço à atuação e à intervenção de ONG'S (Organizações Não Governamentais) e OSCIP'S (Organizações da Sociedade Civil de Interesse Público), além de fundações de empresas privadas que patrocinam o terceiro setor, na formação continuada de professores, seja por meio de projetos pontuais, seja com programas mais estruturados.

A formação do professor é uma demanda fundamental para consolidar um tipo de educação, qualquer que ela seja. Acredita-se que apenas capacitando os docentes é possível concretizar essa ou aquela educação - daí seu caráter estratégico. O governo e a moderação operam nesses entrecruzamentos; o jornal desclassifica a formação, a academia pesquisa sobre a formação, os professores reclamam, a opinião pública sofistica-se. O debate está instalado. Está constituído um campo para intervenção.

Em suas pesquisas, Foucault realiza um deslocamento teórico que se mostra muito importante para entender a complexa relação entre sujeito, poder e verdade. Após a análise dos diferentes mecanismos de poder, há em seus estudos um deslizamento do conceito de poder para o de governo, deslizamento este que, como já exposto aqui, consiste não em uma substituição, mas sim em uma sofisticação, um investimento na temática do governo de si e da autoconstituição. Para ele, não é a questão do poder que constitui o foco de seu interesse, mas sim o problema do sujeito em suas relações com as práticas de dominação, com as técnicas discursivas e em sua autoconstituição por meio das técnicas de si (GROS, 2006).

Entendemos, assim, que o sujeito é constituído e autoconstitui-se num movimento constante e circular. Na influência, no direcionamento e na condução desse movimento, são determinantes as práticas discursivas, práticas derivadas de discursos que formam uma grade de inteligibilidade na qual o sujeito está inserido, operando pelas coordenadas ali apresentadas.

Avançando na compreensão do conceito de governamentalidade, incluímos a reflexão feita por Nikolas Rose (2001b), para quem a linguagem é constitutiva de estratégias governamentalizadoras. Nessa perspectiva, a linguagem não apenas torna os atos de governo descritíveis, mas é ela que possibilita sua existência; como bem resumem Deleuze e Guattari, “a linguagem não é vida, ela dá ordens à vida” (2008, p.18). Tomar a linguagem como agente nos processos de subjetivação, considerando sua relevância na governamentalidade, impõe a necessidade de supor tais subjetivações como movimentos edificados por discursos expostos em enunciados; como estando, 
enfim, articuladas por redes discursivas, as quais inventam, moldam, produzem e anunciam modos e possibilidades de ser e agir no mundo. A subjetivação é uma rede tecida por regimes de significações contidos no interior de relações de poder. É um processo de agenciamento que sincroniza práticas e discursos.

Devemos ter o cuidado de explicitar que não se trata de um processo de dominação. Há espaço para contestações, recusas e escolhas, num jogo de forças que põem em funcionamento significados, valores e a relação do sujeito com processos subjetivadores e com ele próprio. A liberdade, aqui, é fundamental.

Com toda essa discussão sobre regulação e governo, a que liberdade referimonos? Falamos no conceito de liberdade próprio do pensamento moderno que despontou no Iluminismo, fortemente calcado nas ideias de Imannuel Kant. Resumindo o que foi abordado anteriormente, para esse filosofo alemão, a formação do sujeito livre só se dá com a autonomia e a emancipação. O sujeito atinge sua maioridade por meio da razão, da consciência e do esclarecimento (KANT, 1999), e é também por essa via que alcança a liberdade. Esse processo ocorre por meio da formação, e como tais atributos não são inatos ao homem e precisam ser ensinados, a educação é considerada a chave para a emancipação. A liberdade constitui-se, portanto, dentro de um quadro discursivo bem definido; aceitamos ou recusamos coisas tendo como base a razão que adquirimos.

Seguindo por esse pensamento, Foucault pondera que as "Luzes' que descobriram as liberdades inventaram também as disciplinas" (2004b, p.183). A liberdade, como uma invenção moderna, teve as disciplinas como condição de possibilidade para sua gestação, ou seja, para alcançar a posição de um sujeito livre é necessário passar por processos de subjetivação e objetivação das práticas disciplinares e normalizadoras. Nesse sentido, a liberdade que hoje podemos visualizar não funciona como uma liberdade redentora e emancipadora, mas como uma liberdade que, paradoxalmente, ao mesmo tempo em que possibilita práticas de resistência, também regula nossas ações.

O governo está ligado ao modo pelo qual indivíduos livres são levados a governar a si mesmos como sujeitos simultaneamente dotados de liberdade e de responsabilidade. Que haja espaço para iniciativa ou que se permita agir, isso não significa a inexistência de uma gestão de condutas, de uma condução ou de um governo. As relações com a liberdade definem-se particularmente a partir do poder, e não contra ou apesar dele. Tal liberdade regulada oferece escolhas que não operam pela 
subordinação ou pela dominação. O sujeito contemporâneo é um cidadão livre e responsável por suas escolhas, porém devemos entender que tais escolhas não são questões privadas, mas governadas por um conjunto de condições que o inclinam a desejar, escolher e decidir; são escolhas condicionadas a formas divulgadas e conhecidas de pensar, agir e viver.

Pensemos na imbricação disso com as proposições sobre a abertura da escola pública para a comunidade e o voluntariado dos alunos das escolas particulares. O que se propõe nas matérias jornalísticas é um modo de vida e de participação; a partir das ideias de rede e parceria, fica a promessa e a busca por uma transformação da realidade social, por práticas capazes de construir formas de ser voluntário, de ser cidadão, de ser aluno etc. Tais práticas não são determinadas ao acaso ou de forma natural, mas são construídas por diferentes discursos capazes de adentrar a escola e constituir um tipo de currículo.

Nesse movimento, as práticas de voluntariado institucionalizam-se e os discursos da solidariedade passam a ser reguladores de um tipo de sujeito e de uma relação específica entre o Estado e a sociedade. Produz-se entendimentos tanto sobre o papel da docência, com base em fundamentos de vocação, doação e missão, quanto sobre um currículo escolar que seja voltado à participação da comunidade.

As práticas de voluntariado e a participação da comunidade, tão valorizadas e divulgadas pelos artigos jornalísticos, produzem saberes no sentido de transformar os sujeitos para consequentemente atingir determinadas modificações sociais. Elas têm a aceitabilidade e o reconhecimento de todos, uma vez que lidam com questões relacionadas à vida da população. São um chamado à atuação e à consequente constituição de sujeitos que buscam realizar a si mesmos e maximizar sua qualidade de vida, conferindo sentido e valor às suas existências na medida em que se acreditam resultado de escolhas adequadas, responsáveis e autônomas.

Segundo Nikolas Rose (1998), trata-se de compreendermos esse sujeito como cidadão de uma democracia liberal em que os mecanismos de governo constroem-no como participante ativo em sua própria vida. Eis o sujeito moderno, que embora governado por desejos criados, saberes impostos e disciplinas disfarçadas, considera-se o mais livre de todos os homens. Vê-se aí efeitos de processos de governamentalização eficientes que são calculadamente apoiados e divulgados, seja pelos textos mais simples 
ou pelos mais elaborados, por curtas reportagens ou por imensos artigos de opinião veiculados pelo jornal.

\section{2 - O processo de governamentalização: educação do corpo e da alma}

As matérias sobre a educação escolar estão disseminadas por todos os cadernos do jornal, sejam eles sobre economia, política, saúde ou assuntos do cotidiano. Não há, enfim, uma posição específica para o tema, o que lhe confere certa porosidade, tornando possível que ele seja permeado por outros assuntos e que, ao mesmo tempo, atravesse um enorme contingente de conteúdos. Verificamos com isso que a questão da educação, devido a essa maleabilidade que lhe é conferida pelos discursos que a narram, materializa-se como um dos campos fundamentais para as ingerências jornalísticas na vida.

A constância com que a educação escolar é abordada e seu tráfego por muitos dos assuntos enfocados nas notícias diárias levam-nos à ideia de uma espetacularização da educação. Tal noção deriva do conceito definido por Guy Debord (1991) e parece encaixar-se muito bem na dinâmica da cobertura jornalística sobre o tema aqui em

questão. É preciso, entretanto, delimitar algumas diferenças fundamentais entre a ideia que o autor defende e o referencial teórico que adotamos em nosso trabalho.

Conforme a tese defendida por ele no livro A sociedade do espetáculo, tal conceito é uma tentativa de compreensão de uma fase específica da sociedade capitalista, e sua ideia está vinculada a uma interpretação materialista da vida social. Para Debord, o espetáculo é um elemento articulador utilizado pelas intenções capitalistas de criar e manipular representações da realidade. Ele convoca-nos a entender que a realidade se torna uma imagem, ao passo que as imagens tornam-se realidade; as relações, portanto, já não seriam mediadas apenas pelas coisas, mas diretamente pelas imagens. Estas se constituiriam como abstrações do real, e seu predomínio seria o espetáculo. A abstração generalizada, porém, corresponderia a uma consequência da sociedade capitalista da mercadoria, da qual o espetáculo seria a forma mais desenvolvida, ou, nas palavras do próprio autor, “o espetáculo é o momento em que a mercadoria chega à ocupação total da vida social. Não só a relação com a mercadoria é visível, como nada mais se vê senão ela: o mundo que se vê é o seu mundo" (DEBORD, 1991, p.31). 
As contribuições de Debord foram numerosas para a compreensão do mecanismo articulador da circulação de discursos; por outro lado, porém, a noção de espetáculo aparece como uma forma alienante de manipulação ideológica e um mecanismo de passividade, contendo uma noção de essência bastante conflitante com o pensamento foucaultiano. Debord considera que a realidade é ocultada ou maquiada, cabendo ao espetáculo o papel de mascará-la e de separar os sujeitos de uma verdade essencial; segundo esse pensamento, seria possível retirar o véu que encobre o real e reconciliar o sujeito com a verdade.

Tanto Foucault quanto Debord operam com a ideia de que as noções encontradas e conhecidas em determinado contexto histórico não são naturais; para o primeiro, porém, não existe uma essência, uma verdade a priori, mas sim um mundo em constante luta, em processo e em transformação. Foucault não procura encontrar uma natureza intrínseca às coisas, mas estuda a relação do sujeito com as verdades de cada época. Assim, para ele, não há uma essência humana que tenha sido mascarada, alienada ou aprisionada por meios repressivos, após certo número de processos históricos, econômicos e sociais. A crença de que basta romper com mecanismos de repressão para que o homem se reconcilie consigo mesmo, reencontre sua própria natureza e retome contato com sua origem é, para o pensamento foucaultiano, mera ilusão.

Para esclarecer melhor esse contraponto, podemos afirmar que, nos artigos de jornal, a educação escolar converteu-se em uma educação-espetáculo. Os textos e seus sentidos circulam constituindo uma educação que se tornou plástica, inspirada num modelo ideal e constantemente construída e reconstruída em imagens. O mundo da escola torna-se, então, um imenso parque de fulgurações que oferece imagens a serem contempladas, consumidas ou rejeitadas. A partir delas, os sujeitos vivenciam ideias e valores em nome de um discurso proferido como válido por regimes de verdade construídos no jornal em conexão com outros enunciados que produzem certa realidade, em certo tempo e por certo período. Esse discurso é uma prática fundamental na gerência e no controle das condutas, e atua no modo como o sujeito relaciona-se consigo mesmo e com o outro. Ele flexiona a atuação do sujeito no mundo enunciado, seja levando-o a aceitar as disposições apresentadas, seja levando-o a posicionar-se contra elas. 
Não se trata aí de uma coação ou de uma imposição que fixa o sujeito em um determinismo; governar, na acepção aqui utilizada, é

estruturar o eventual campo de ação dos outros. [...] O poder só se exerce sobre 'sujeitos livres', enquanto 'livres' entendendo-se por isso sujeitos individuais ou coletivos que têm diante de si um campo de possibilidade onde diversas condutas, diversas reações e diversos modos de comportamentos podem acontecer (FOUCAULT, 1995, p.244).

Podemos concluir, pois, que o papel da imprensa nesse jogo é fundamental, não para alienar o sujeito com modos e representações falseadas de uma realidade, mas no sentido de constituir um repertório juntamente com outras instâncias. Os ditos sobre a escola são autorizados e validados, compondo o que entendemos e vivenciamos como realidade. Assim, as verdades circulantes sobre a instituição escolar e sua educação fazem parte dessa realidade, e controlar seu funcionamento, em termos de regulação e direção, mostra-se importante para que se efetuem as práticas de governamentalização da população.

Ao analisar a iminência das práticas de governo impressa nos enunciados jornalísticos, encontramos um discurso que encerra técnicas e modos de regulação, e que tem como objeto a população, visando à geração de certas subjetividades. Tal conjunto de estratégias é atravessado por diversos saberes que corroboram sua veridicção, num movimento ondulante de produção de efeitos de realidade ou de verdade. Governar, nesse sentido, significa conduzir condutas em um duplo aspecto: tanto em referência à "atividade que consiste em conduzir", quanto à "maneira pela qual conduzimos a nós mesmos, o modo pelo qual nos deixamos conduzir, a maneira pela qual somos conduzidos e pela qual, enfim, nos comportamos sob efeito de uma conduta, que seria ato de conduta ou de condução" (Foucault, 2008c, p.197). A atividade de conduzir condutas, pois, é inseparável da maneira de conduzir-se e da atitude de resistência a uma condução específica. Há, nesse movimento, uma responsabilização dos indivíduos, levando-os à tomada de decisão supostamente livre nos campos de ação.

O processo de governamentalização efetiva-se pela desqualificação e pelos elementos dela decorrentes - má educação, baixo desenvolvimento, atraso econômico, violência, desigualdade etc. É possível dizer, a partir de nossa análise, que determinada educação é apontada como salvadora, mas que esta não corresponde à educação produzida, descrita e narrada como aquela que factualmente se produz. Trata-se, em vez 
disso, de uma educação ideal apresentada nos enunciados, legitimada por estudos e encontrada em outros países - desenvolvidos, em sua maioria - e em algumas poucas escolas privadas.

Além disso, os enunciados transmitidos pelos jornais fornecem linguagens específicas para a compreensão dessa educação idílica, bem como a base de competências necessárias para que ela funcione da forma almejada. Eles delineiam, assim, uma diversidade de maneiras para que os ditos problemas educacionais sejam tornados inteligíveis e passíveis de intervenção.

Explicita-se, nesse processo, uma gestão pastoral que se efetiva por meio da convocação e da persuasão. Isso porque a prática discursiva materializada pelos enunciados jornalísticos atua não por uma dominação do sujeito, mas por um movimento segundo o qual ele deve ser educado e convencido a engajar-se em uma espécie de aliança entre seus objetivos e ambições pessoais e os objetivos e atividades institucionais socialmente valorizadas. É à distância e a céu aberto, pois, que esse tipo de governo opera.

Os experts que escrevem, analisam e fornecem prescrições sobre educação nas páginas dos impressos diários não se restringem aos educadores, mas são oriundos das mais diversas áreas, compondo um quadro diversificado. Trata-se de um traço muito peculiar encontrado no discurso sobre a educação: não importa a formação dos falantes, todos opinam e ajuizam sobre o tema. Essa miscelânea de vozes conduz a uma gestão pastoral, convocando - à distância, frise-se mais uma vez - a uma vida plena e realizada, e induzindo seu leitor a compreender e afiançar a importância de um tipo de educação para o bem-estar tanto individual, quanto coletivo.

A discursividade em torno dessa temática produz e reforça conceitos autonomia, democracia, responsabilidade, comunhão etc. - que dão sustentação a uma lógica econômica e política com vistas à edificação de uma educação crítica capaz de gerar um sujeito cidadão, produtivo e consciente de seus direitos e deveres. Isso nos leva a vislumbrar uma triangulação governamentalizadora atuando pelos e para além dos enunciados circulantes nos diários impressos. Vejamos.

Começando pelo vértice da sustentação ética do discurso, pode-se dizer que tais enunciados atuam como um apelo em que se estabelecem balizas de conduta e pensamento; ou seja, a partir de um caráter aparentemente ético, eles convocam a um 
modo de vida vinculado ao bem-estar, à responsabilidade social e ao exercício da cidadania. Junto a esses argumentos, irrompe uma abundância de racionalidades promotoras da educabilidade das formas e modos de vida. Aprende-se a viver de determinado modo, com certos valores e para fins específicos. O viver é matéria a ser aprendida, habilidade a ser desenvolvida, competência a ser adquirida. Tem-se aí um projeto que prioriza, entre outras coisas, as obrigações voluntariamente assumidas por indivíduos livres que poderiam tirar maior proveito de suas próprias existências mediante a gestão responsável de suas vidas.

Incorporado a esse pastorado exercido pela via jornalística, deparamos com um movimento extensivo de pedagogização da educação escolar. As reportagens e principalmente os artigos de opinião operam uma transmissão de ideias por meio de prescrições disciplinares e reguladoras. Tais ideias expressam conhecimentos, maneiras de fazer, modos de produzir ações; em resumo, a maioria dos artigos ensina à escola como ela própria deve operar, narrando aos atores do palco educativo um modo adequado de educar e professando um ideal de sujeito a ser formado, bem como um modelo de sociedade a ser concretizado. Essa pedagogização constitui o segundo vértice da triangulação, operando por meio do discurso e articulando relações de poder-saber num esforço de governo da população.

A esses dois vértices soma-se um terceiro, que tem como base a prática enunciativa de transpor ao sujeito a tarefa de urdir a boa escola. Tal convocação ocorre pelo viés da racionalização educacional presente nas amostras de qualidade veiculadas pelas matérias, as quais descrevem os oásis existentes no interior do deserto educacional tal como ele se apresenta. O processo efetua-se pela disseminação de uma responsabilização que, caso seja levada a cabo, contém em si a promessa de uma transformação individual e coletiva, resultando numa participação ativa na redenção e no aperfeiçoamento da escola e, consequentemente, da sociedade.

O amálgama desse processo dá-se pela proposição da unificação em torno de um ideal comum. A escola é chamada a abrir-se para a comunidade, que, por sua vez, é convidada a colaborar com o aperfeiçoamento da instituição. Como já vimos anteriormente, a ideia de comunidade traduz-se numa unidade em torno de um valor, um objetivo e um pertencimento. Nesse jogo, há novamente um chamado à salvação que traz em seu âmago uma ação de cuidado: cada membro cuida do outro, e todos zelam pela instituição. Tal cuidado constitui uma rede de policiamento convocada a 
atuar na escola, tornando a comunidade um ponto-chave no processo de governamentalização escolar. Conjuga-se, assim, um controle mútuo apoiado em determinados padrões sobre o que é correto, ou não, fazer; há uma disseminação de uma forma politicamente correta de agir. Juntos, esses vetores ensejam um modo coletivo de controle e regulamentação das vidas escolares.

A comunidade, essa noção porosa e maleável, permite a expansão das intervenções educacionais para além dos muros da escola. A escola educa e é educada; o entorno cuida e é cuidado. Retomando as ideias de Peter Pál Pelbart sobre o pensamento de Jean-Luc Nancy, o conceito de comunidade figura como uma grande ilusão produzida pelo projeto moderno, que intencionou forjar um sujeito constituído pela imagem de um corpo comum, viabilizada por intermédio de uma identificação homogênea fundada no pertencimento. A convocação a esse pertencer investe em relações capilares de associação com vistas à formação de um cidadão integral. Sob a rubrica de ações pedagógicas, há a proposta de uma intervenção ampla baseada na suposição de que apenas a sociedade como um todo é capaz de construir uma educação de qualidade.

Tal movimento remete a uma desobrigação do Estado, desvinculando as instâncias governamentais - ao menos, em parte - das funções de controle e das preocupações com questões sociais. Esse processo de descentralização, flexibilização e fortalecimento da sociedade civil opera concomitantemente à formação de um sujeito que não mais possui a opção de não ser ou de não fazer. Como bem explica Giorgio Agamben, trata-se de "uma outra e mais dissimulada operação do poder, que não age imediatamente sobre o que os homens podem fazer - sobre sua potência -, mas antes sobre a sua impotência, isto é sobre o que não podem fazer ou, melhor, podem não fazer" (2010, p.57). Na contemporaneidade, os homens são constantemente chamados, convocados, aliciados a fazerem e a serem uma pletora de coisas, estando impedidos de recusar; é, pois, nesse combate à recusa que "prefere agir o poder que se define ironicamente como 'democracia"' (p.58).

Ao analisar toda essa rede de técnicas e estratégias que se efetuam nos processos de governamentalização social, defrontamos com um paradoxo: a apregoada crise escolar, entendida como um estado de declínio e incerteza, é acompanhada por uma hipervalorização da pedagogia, em um sentido expandido. A escola continua sendo uma instituição de sequestro no que concerne aos alunos regulares, mas amplia suas 
fronteiras, convocando todos ao engajamento a uma educação que ultrapasse os muros escolares e da qual todos participem.

Encontramos também um deslocamento da atribuição teoricamente basal dessa instituição: a de a escola ser uma instituição-chave no controle e governo da população. Sua gestão é efeito de relações de força, resultado de uma permutação de processos históricos, econômicos e culturais, sendo, portanto, passível de reprogramações de rotas e objetivos. Elaborando desse modo nosso pensamento sobre a instituição escolar, abandonamos a ideia de progresso que a situa num caminho evolucionista, e a posicionamos como efeito de um jogo complexo de forças que a faz emergir tal como se encontra.

O que os textos analisados nos apontam é que a escola precisa ser mais do que ela já foi. Controlar o caminhar dessa instituição é uma das táticas para que tal objetivo seja atingido, tática esta seguida à risca por aqueles que ecoam suas vozes nas folhas do jornal. Ali deparamos com cálculos que tentam prescrever o que a escola deverá tornarse, discriminando o que ela não deve continuar a ser. Compõe-se, assim, um conjunto de elementos que estão no entorno da verdade apresentada e do papel político que ela exerce. Nesse sentido, prosseguimos com Foucault, que define bem o que gostaríamos de dizer: "Em suma, a questão política não é o erro, a ilusão, a consciência alienada ou a ideologia; é a própria verdade" (2006c, p.14).

Por fim, de volta às notícias, enquanto estas são lidas, discutidas, repetidas e legitimadas, concretiza-se a afirmação de um mundo e supõe-se a exclusão de outros possíveis. O que se excluem são as possibilidades existentes para além dos lados A e B; são as possibilidades que contemplam o $\mathrm{C}$, o D, o Y; em suma, o fato mesmo de que podemos inventar outras vidas a serem vividas. O discurso autorizado pelos saberes vigentes e referenciado pelas mídias situa os indivíduos numa trilha, num caminho de verdade, sem explicitar que essa verdade é tão inventada como a vida que ela conforma. 


\section{REFERÊNCIAS}

Abreu, Ana Silvia Couto de. Escola e escola on-line: alguns efeitos do discurso pedagógico midiatizado. 85f. Tese (Doutorado em Educação) - Faculdade de Educação, Universidade Estadual de Campinas, Campinas, 2006.

Agamben, Giorgio. O que é o contemporâneo? e outros ensaios. Chapecó: Argos, 2009.

Nudez. Lisboa: Relogio D’ Agua, 2010.

ANJos, Cleriston Izidro dos. A educação infantil representada: uma análise da revista Nova Escola (2005-2007). 124f. Dissertação (Mestrado em Educação) - Faculdade de Educação, Universidade de São Paulo, São Paulo, 2008.

AQUINO, Julio Groppa. A pedadogização do pedagógico: sobre o jogo do expert no governamento docente, 2011 (mimeo).

AQuino, Julio Groppa; RIBEIRO, Cintya Ribeiro. Processos de governamentalização e a atualidade educacional: a liberdade como eixo problematizador. Educação e Realidade, v.34, p.57-71, 2009.

BACCEGA, Maria Aparecida. Da comunicação à comunicação/educação. Comunicação \& Educação. v.7, n.21, 2001. Disponível em: http://www.usp.br/comueduc/index.php/ comueduc/ article/view/536/533. Acessado em: 26 nov. 2010.

BAHIA, Juarez. Jornal, história e técnica II: as técnicas do jornalismo. São Paulo: Ática, 1999.

BAuman, Zygmunt. Modernidade líquida. Rio de Janeiro: Jorge Zahar Editor, 2007.

Brasil. Ministério da Educação e do Desporto. Plano Decenal de Educação para Todos. Brasília, DF: MEC, 1993. Disponível em: http://www.dominiopublico.gov.br/ download/texto/me001523.pdf. Acessado em: 20 dez. 2010.

BrASIL. Lei 9.394, publicada em 20 de dezembro de 1996. Lei de Diretrizes e Bases da Educação Nacional (LDBN). Disponível em: http://portal.mec.gov.br/seed/arquivos/ pdf/tvescola/leis/lein9394.pdf. Acessado em: 20 dez. 2010.

BRASIL. Ministério da Educação. Secretaria de Educação Básica. Instituto Nacional de Estudos e Pesquisas Educacionais Anísio Teixeira - INEP. Censo Escolar da Educação Básica. Brasília: MEC/SEB, 2010. Disponível em: http://www.inep.gov.br/download/ censo/2010/apresentacao_divulgacao_censo_2010.pdf. Acessado em: 02 jan. 2011.

CALDAS, Graças. Mídia, escola e leitura crítica do mundo. Educação e Sociedade, v.27, n.94, p.117-130, 2006.

CANCIAN, Edivania Pinheiro Ferreira. O discurso de uma revista especializada em educação: um olhar sobre a construção metafórica do professor. 81f. Dissertação (Mestrado em Linguística) - Pontifícia Universidade Católica, São Paulo, 2008.

Chaparro, Manuel Carlos. Pragmática do jornalismo: buscas práticas para uma teoria da ação jornalística. São Paulo: Summus, 2007. 
CRIPA, Marcos Luiz. Cobertura da educação no jornal Folha de São Paulo: uma análise comparativa dos anos 1973 e 2002. 189f. Dissertação (Mestrado em Ciências da Comunicação). Escola de Comunições e Artes, Universidade de São Paulo, São Paulo, 2008.

Costa, Marisa Vorraber (org.). Estudos culturais em educação: mídia, arquitetura, brinquedo, biologia, literatura, cinema... Porto Alegre: Ed. Universidade/UFRGS, 2000.

Ensinando a dividir o mundo: as perversas lições de um programa de televisão. Revista Brasileira de Educação, n.2, p.71-82, mai./jun./jul./ago. 2002.

DeBord, Guy. A sociedade do espetáculo. Lisboa: Mobilis in Mobile, 1991.

DELEUZE, Gilles. Conversações: 1972-1990. Rio de Janeiro: Editora 34, 1992. . O ato de criação. Folha de São Paulo, Caderno Mais, p.4-5, 27 jun. 1999. Foucault. São Paulo: Brasiliense, 2006.

Deleuze, Gilles; Guattari, Félix. Postulados da lingüística. In: Mil platôs: capitalismo e esquizofrenia, vol. 2. Rio de Janeiro: Editora 34, 2008. p.11-59.

ERIBON, Didier. Michel Foucault: 1920-1984. São Paulo: Companhia da Letras, 1990.

FISCHER, Rosa Maria Bueno. 1996. Adolescência em discurso: mídia e produção de subjetividade. 297f. Tese (Doutorado em Educação) - Programa de Pós-Graduação em Educação, Faculdade de Educação, Universidade Federal do Rio Grande do Sul, Porto Alegre, 1996.

O estatuto pedagógico da mídia: questões de análise. Educação \& Realidade, v.22, n.2, p.59-80, jul./dez. 1997.

Foucault e a análise do discurso em educação. Cadernos de Pesquisa, n.114, p.197-223, nov. 2001.

O dispositivo pedagógico da mídia: modos de educar na (e pela) TV. Educação e pesquisa, v.28, n.1, p.151-162, jan./jun. 2002a.

Problematizações sobre o exercício de ver: mídia e pesquisa em educação. Revista Brasileira de Educação, n.20, p.83-94, mai./jun./jul./ago. 2002b.

Mídia e juventude: experiências do público e do privado na cultura. Caderno Cedes, v.25, n.65, p.43-58, jan./abr. 2005a.

Mídia e educação: em cena, modos de existência jovem. Educar em Revista, v.26, p.17-38, jul./dez. 2005b.

Mídias, máquinas de imagens e práticas pedagógicas. Revista Brasileira de Educação. v.12, n.35. p.290-299, 2007.

FonseCA, Ana Paula Azarias. A construção da educação na revista Veja. 116f. Dissertação (Mestrado em Comunicação). Pontifícia Universidade Católica, São Paulo. 2008. 
Foucault, Michel. História da sexualidade 2: o uso dos prazeres. Rio de janeiro: Edições Graal, 1994.

O sujeito e o poder. In: DreYFus, Hubert; RABINOw, Paul. Michel Foucault, uma trajetória filosófica: para além do estruturalismo e da hermenêutica. Rio de Janeiro: Forense Universitária, 1995. p.231-249.

Zahar Editor, 1997.

Resumos dos cursos do Collège de France (1970-1982). Rio de Janeiro: Jorge 1999.

História da sexualidade 3: o cuidado de si. Rio de janeiro: Edições Graal,

\section{9.}

. Os anormais. São Paulo: Martins Fontes, 2002.

. A ordem do discurso. São Paulo: Edições Loyola, 2004a.

. Vigiar e punir. Petrópolis: Vozes, 2004b.

. A verdade e as formas jurídicas. Rio de Janeiro: Nau, 2005a.

. Em defesa da sociedade. São Paulo: Martins Fontes, 2005 b.

. O nascimento da clínica. Rio de Janeiro: Forense Universitária, 2006a.

$\frac{}{2006 \mathrm{~b} .}$. História da sexualidade I: a vontade de saber. Rio de janeiro: Edições Graal,

. Verdade e poder. In: Graal, 2006c. p.1-14. Microfísica do poder. Rio de Janeiro: Edições

. Polêmica, política e problematizações. In: Ditos e escritos V: ética, sexualidade, política. Rio de Janeiro: Forense Universitária, 2006d. p.225-234.

O cuidado com a verdade. In: Ditos e escritos $V$ : ética, sexualidade, política. Rio de Janeiro: Forense Universitária, 2006d. p.240-251.

A ética do cuidado de si como prática da liberdade. In: Ditos e escritos $V$ : ética, sexualidade, política. Rio de Janeiro: Forense Universitária, 2006d. p.264-287.

Verdade, poder e si mesmo. In: Ditos e escritos $V$ : ética, sexualidade, política. Rio de Janeiro: Forense Universitária, 2006d. p.294-300.

. História da loucura. São Paulo: Perspectiva, 2007a.

. Arqueologia do saber. Rio de Janeiro: Forense Universitária, 2007b.

. As palavras e as coisas. São Paulo: Martins Fontes, 2007c.

. Nascimento da biopolítica. São Paulo: Martins Fontes, 2008a.

- A reportagem de ideias. In: Berger, Christa; MArroco, Beatriz. Ilha do presídio: uma reportagem de ideias. Porto Alegre: Libreto, 2008b. p. 49-51.

. Segurança, território, população. São Paulo: Martins Fontes, 2008c. 
Do governo dos vivos: curso no Collège de France, 1979-1980 (excertos). São Paulo: Centro de Cultura Social; Rio de Janeiro: Achiamé, 2010a.

Por uma moral do desconforto. In: Ditos e escritos VI: Repensar a política. Rio de Janeiro: Forense Universitária, 2010b. p. 279-284.

Gros, Frédéric. Situação do curso. In: Foucault, Michel. A hermenêutica do sujeito. São Paulo: Martins Fontes, 2006. p.613-661.

KANT, Immanuel. Resposta a uma pergunta: o que é esclarecimento. In: Textos seletos. Petrópolis: Vozes, 2005. p.63-71.

Sobre a pedagogia. Piracicaba: UNIMEP, 1999.

MACHADO, Roberto. Nietzsche e a verdade. Rio de Janeiro: Edições Graal, 2002.

MARANHÃo, Carlos André Cantisani. Quitungo, mídia e cidadania: a política de "mídia e educação" da prefeitura do Rio de Janeiro em uma perspectiva discursiva e comunitária. 128f. Dissertação (Mestrado em Educação) - Faculdade de Educação, Universidade de São Paulo, São Paulo, 2007.

Marcello, Fabiana de Amorim. O conceito de dispositivo em Foucault: mídia e produção agonística de sujeitos-maternos. Educação \& Realidade, v.29, n.1, p.199-213, jan./jun. 2004.

Dispositivo da maternidade: mídia e a produção pedagógica de sujeitos, práticas e normas. Educar em Revista, v.26, p.81-98, jul./dez. 2005.

MAREuSE, Marcia Aparecida Giuzi. A representação infantil da violência na mídia: uma perspectiva para repensar a educação. 329f. Tese (Doutorado em Ciências da Comunicação) - Escola de Comunicações e Artes, Universidade de São Paulo, São Paulo, 2007.

MEDRADO, Benedito. Textos em cena: a mídia como prática discursiva. In: SPINK, Mary Jane (org.). Práticas discursivas e produção de sentidos no cotidiano: aproximações teóricas e metodológicas. São Paulo: Cortez, 1999. p.243-271.

NIETZSCHE, Friedrich. Sobre verdade e mentira. São Paulo: Hedra, 2009.

Novelli, Ana Lucia. O projeto Folha e a negação do quarto poder. In: MotTA, Luiz Gonzaga (org.) Imprensa e poder. Brasília: UnB-Imprensa Oficial, 2002.

Ó, Jorge Ramos do. O Governo de si mesmo: modernidade pedagógica e encenações disciplinares do aluno liceal (último quartel do século XIX - meados do século XX), Lisboa: Educa, 2003.

Orlandi, Eni Puccinelli. As formas do silêncio. Campinas: Editora Unicamp, 1992.

PARAíso, Marlucy Alves. Currículo e mídia: a produção de um discurso para e sobre a escola. Educação em Revista, n.34, p.67-84, dez. 2001.

Pelbart, Peter Pál. A comunidade dos sem comunidade. In: Vida capital: ensaios de biopolítica. São Paulo: Iluminuras, 2003. p.28-41. 
POPKEwITZ, Thomas. História do currículo, regulação social e poder. In: SiLVA, Tomaz Tadeu da (org.). O sujeito da educação: estudos foucaltianos. Petrópolis: Vozes, 1994. p.173-210.

PRAdo FILHO, Kleber. Michel Foucault: uma história da governamentalidade. Rio de Janeiro: Insular e Achiamé, 2006.

PRESSER, Margaret. A recepção das mensagens televisivas e a construção do sentido: uma experiência. 151f. Dissertação (Mestrado em Ciências da Comunicação) - Escola de Comunicações e Artes, Universidade de São Paulo, São Paulo, 2007.

RicARdo Filho, Geraldo Sabino. A boa escola no discurso da mídia: um exame das representações sobre educação na revista Veja (1995-2001). São Paulo: Editora UNESP, 2005.

RochA, Cristianne Maria Famer. A escola na mídia: nada fora do controle. 289f. Tese (Doutorado em Educação) - Faculdade de Educação, Universidade Federal do Rio Grande do Sul, Porto Alegre, 2005.

Rose, Nikolas. Governando a alma: a formação do eu privado. In: SILVA, Tomaz Tadeu da (org.). Liberdades reguladas. Petrópolis: Vozes, 1998. p.30-45. 57, 2001a.

Como se deve fazer a história do eu. Educação \& Realidade, v.26, n.1, p.33-

Inventando nossos eus. In: SILVA, Tomaz Tadeu da (org.). Nunca fomos humanos: nos rastros do sujeito. Belo Horizonte: Autêntica, 2001b. p.139-204.

SANTOS, Cláudia Amaral dos. O discurso dos experts na constituição das identidades infantis e de gênero na mídia impressa brasileira. Pro-Posições, v.16, n.3, p.213-228, set./out. 2005.

SetTon, Maria da Graça. A mídia e o ensino superior: é possível a criação de um consenso? Educação \& Realidade, v.27, n.1, p.151-182, 2002.

Silva, Tomaz Tadeu da. O currículo como fetiche: a poética e a política do texto curricular. Belo Horizonte: Autêntica, 2003.

SILVEIRA, Fernanda Romanezi da. Um estudo das capas da Revista Nova Escola: 19862004. 149f. Dissertação (Mestrado em Educação) - Faculdade de Educação, Universidade Estadual de Campinas, Campinas, 2006.

SOMMERHALDER-MIIKE, Helenita. Oficina de TV, uma prática educomunicativa: estudo de caso de uma criança abrigada. 173f. Dissertação (Mestrado em Ciências/Psicologia) - Faculdade de Filosofia, Ciências e Letras de Ribeirão Preto, Universidade de São Paulo, Riberão Preto, 2008.

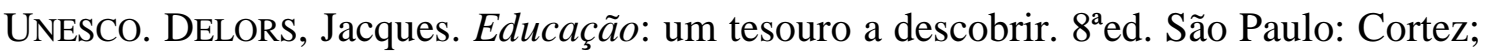
Brasília, DF: MEC, UNESCO, 2003.

UNESCO (coord.). Declaração mundial sobre educação para todos: plano de ação para satisfazer as necessidades de aprendizagem. Nova Iorque: WCEFA, 1990.

VeIgA-Neto, Alfredo. Foucault \& a educação. Belo Horizonte: Autêntica, 2004. 
VeYne, Paul. Foucault, o pensamento, a pessoa. Lisboa: Edições Texto \& Grafia, 2009. 


\section{Bibliografia CONSUltadA}

Agamben, Giorgio. A idéia da prosa. Lisboa: Edições Cotovia, 1999.

A linguagem e a morte: um seminário sobre o lugar da negatividade. Belo Horizonte: Editora UFMG, 2006.

Profanações. São Paulo: Boitempo, 2007.

Albuquerque Júnior, Durval Muniz de; Veiga-Neto, Alfredo; Sousa Filho, Alípio de (orgs.). Cartografias de Foucault. Belo Horizonte: Autêntica, 2008.

BuJES, Maria Isabel Edelweiss. Infância e maquinarias. Rio de Janeiro: DP\&A, 2003.

CAStro, Edgardo. Vocabulário de Foucault. Belo Horizonte: Autêntica, 2009.

CorAzZA, Sandra Mara. Laboratórios de pesquisas, diante dos ferrolhos. In: CostA, Marisa Vorraber (org.). Caminhos investigativos: novos olhares na pesquisa em educação. Rio de Janeiro: DP\&A, 2002. p.105-131.

CORRÊA, Guilherme. Do livro de receitas: como produzir um homem. In: PASSETTI, Edson. Kafka, Foucault: sem medos. Cotia: Ateliê Editorial, 2004. p.45-54.

DEBorD, Guy. A sociedade do espetáculo. Lisboa: Mobilis in Mobile, 1991.

DreYFus, Hubert; Rabinow, Paul. Michel Foucault, uma trajetória filosófica. Rio de Janeiro: Forense, 1995.

Fischer, Rosa Maria Bueno. Mídia, estratégias de linguagem e produção de sujeitos. In: CANDAU, Vera Maria (org.). Linguagens, espaços e tempos no ensinar e aprender. Rio de Janeiro: DP\&A, 2000. p.75-88.

FONSECA, Márcio. Michel Foucault e a constituição do sujeito. São Paulo: EDUC, 1995.

FOUCAULT, Michel. Estruturalismo e pós-estruturalismo. In: Ditos e escritos II: arqueologia das ciências e história dos sistemas de pensamento. Rio de Janeiro: Forense Universitária, 2000. p.307-334.

Omnes et Singulatim: uma crítica da razão pura. In: Ditos e escritos VI: estratégia, poder-saber. Rio de Janeiro: Forense Universitária, 2006. p.335-385.

GERZSON, Vera. A mídia como dispositivo da governamentalidade neoliberal: os discursos sobre educação nas revistas Veja, Época e Istoé. 164f. Tese (Doutorado em Educação) - Faculdade de Educação, Universidade Federal do Rio Grande do Sul, Porto Alegre, 2007.

GOMES, Mayra Rodrigues. Repetição e diferença nas reflexões sobre comunicação. São Paulo: Annablume, 2001.

Edusp, 2003.

Poder no jornalismo: discorrer, disciplinar, controlar. São Paulo: Hacker/ 
Gregolin, Maria do Rosário (org.). Discurso e Mídia: a cultura do espetáculo. São Carlos: Claraluz, 2003.

Gros, Frédéric (org.). Foucault: a coragem da verdade. São Paulo: Parábola Editorial, 2004.

KELLNER, Douglas. A cultura da mídia - estudos culturais: identidade e política entre o moderno e o pós-moderno. Bauru: EDUSC, 2001.

LARRoSA, Jorge. Pedagogia profana: danças, piruetas e mascaradas. Belo Horizonte: Autêntica, 2004.

MACHAdO, Roberto. Foucault, a ciência e o saber. Rio de Janeiro: Jorge Zahar Editor, 2006.

Orlandi, Eni Puccinelli. Discurso e texto: formulação e circulação dos sentidos. Campinas: Pontes, 2001.

Peters, Michel; Besley, Tina. Por que Foucault? Novas diretrizes para a pesquisa educacional. Porto Alegre: Artmed, 2008.

RAGO, Margareth; ORLANDI, Luiz B. Lacerda; VeIGA-Neto, Alfredo (orgs.). Imagens de Foucault e Deleuze. Rio de Janeiro: DP\&A, 2005.

Rago, Margareth; VeIGA-Neto, Alfredo. Figuras de Foucault. Belo Horizonte: Autêntica, 2006.

REVEL, Judith. Foucault: conceitos essenciais. São Carlos: Claraluz, 2005.

Sargentine, Vanice; NAVArro-Barbosa, Pedro (orgs.). Michel Foucault e os domínios da linguagem: discurso, poder e subjetividade. São Carlos: Claraluz, 2004.

Scavone, Lucila; Alvarez, Marcos César; Miskolci, Richard (orgs.). O legado de Foucault. São Paulo: Editora UNESP, 2006.

SENELlART, Michel. As artes de governar: do regime medieval ao conceito de governo. São Paulo: Editora 34, 2006.

Silva, Tomaz Tadeu da (org.). O sujeito da educação. Petrópolis: Vozes, 1994.

Liberdades reguladas: a pedagogia construtivista e outras formas de governo do eu. Petrópolis: Vozes, 1998.

Nunca fomos humanos: nos rastros do sujeito. Belo Horizonte: Autêntica, 2001.

VARELA, Julia. Categorias espaços-temporais e socialização escolar: do individualismo ao narcismo. In: CostA, Marisa Vorraber (org.). Escola básica na virada do século: cultura, política e currículo. São Paulo: Cortez, 1996.

Varela, Julia; Alvarez-Uria, Fernando. A maquinaria escolar. Teoria \& Educação, n.6, p.68-96, 1992.

VeIGA-Neto, Alfredo. Educação e governamentalidade neoliberal: novos dispositivos, novas subjetividades. In: PORTOCARRERO, Vera; CASTElo BRANCO, Guilherme (orgs.). Retratos de Foucault. Rio de Janeiro: NAU, 2000. p.179-217. 
Olhares... In: CostA, Marisa Vorraber (org.). Caminhos Investigativos: novos olhares na pesquisa em educação. Rio de Janeiro: DP\&A, 2002. p.23-38.

Pensar a escola como uma instituição que pelo menos garanta a manutenção das conquistas fundamentais da modernidade. In: COSTA, Marisa Vorraber (org.). A escola tem futuro? Rio de Janeiro: DP\&A, 2003. p.103-126.

Coisas de governo. In: RAGO, Margareth; ORLANDI, Luiz B. Lacerda; VEIGANETO, Alfredo (orgs.). Imagens de Foucault e Deleuze: ressonâncias nietzschianas. Rio de Janeiro: DP\&A, 2005. p.13-34.

Crise da modernidade e inovações curriculares. Da disciplina para o controle. Sísifo. Revista de Ciências da Educação, n.7, p.141-150, 2008. Disponível em: <http:// sisifo.fpce.ul.pt>. Acessado em: mai. 2009. 


\section{FONTES}

AtHiAs, Gabriela. Secretário da Educação quer mudar currículo. Folha de São Paulo. Cotidiano. 27 dez. 2000. Disponível em: <http://www1.folha.uol.com.br/fsp/cotidian/ff 2712200018.htm.> Acessado em: 26 nov. 2010.

Athias, Gabriela. Escola terá liberdade para definir currículo. Folha de São Paulo. Otidiano. 09 dez. 2001. Disponível em: <http://www1.folha.uol.com.br/fsp/cotidian/ff0 91 2200113.htm.> Acessado em: 26 nov. 2010

AввAтE, Vinicius. Instituições devem estimular a autonomia e a cooperação. Folha de São Paulo. Caderno especial. 24 set. 2006. Disponível em: <http://www1.folha.uol.com .br/fsp/cotidian/ff2409200626.htm.> Acessado em: 26 nov. 2010

AвbAte, Vinicius. Para escolher a escola, pais e filhos devem ser ouvidos. Folha de São Paulo. Cotidiano. 24 set. 2006. Disponível em: <http://www1.folha.uol.com.br/fsp/cotid ian/ff2409200 624.htm.> Acessado em: 26 nov. 2010.

Abramo, Cláudio Weber. A educação e o desgoverno. Folha de São Paulo. Opinião. 04.mar.1999. Disponível em: <http://www1.folha.uol.com.br/fsp/opiniao/fz04039910.h tm.> Acessado em: 26 nov. 2010.

Aguiar, Mauro de Salles. Escola é o professor. Folha de São Paulo. Opinião. 20 ago. 2003. Disponível em: 〈http://www1.folha.uol.com.br/fsp/opiniao/fz2008200310.htm.> Acessado em: 13 abr. 2010.

Alckmin, Geraldo. Pode entrar que a escola é sua. Folha de São Paulo. Opinião. 24 ago. 2003. Disponível em: <http://www1.folha.uol.com.br/fsp/opiniao/fz2408200308.h tm.> Acessado em: 26 nov. 2010. Acessado em: 26 nov. 2010.

Alves, Rubem . Qualidade em educação. Folha de São Paulo. Opinião. 03 jul. 1997. Disponível em: <http://www1.folha.uol.com.br/fsp/opiniao/fz030710.htm.> Acessado em: 26 nov. 2010.

Alves, Rubem. A avaliação da performance das escolas. Folha de São Paulo. Sinapse. 30.ago.2005. Disponível em: <http://www1.folha.uol.com.br/fsp/sinapse/sa3008200513 .htm.> Acessado em: 13 abr. 2010.

Amaral, Luis Henrique. Alunos de $4^{\mathrm{a}}$ e $8^{\mathrm{a}}$ séries fazem "provão". Folha de São Paulo. Cotidiano. 18 abr. 1997. Disponível em: <http://www1.folha.uol.com.br/fsp/cotidian/ff 180423.htm.> Acessado em: 26 nov. 2010.

Amato, Fábio. Contra danos, escola instala câmeras nos banheiros. Folha de São Paulo. Cotidiano. 05 dez. 2006. Disponível em: <http://www1.folha.uol.com.br/fs p/cotidian/ff051220061 5.htm.> Acessado em: 26 nov. 2010.

ARANTES, Flavio. MEC elogia projeto de ciclos em São Paulo. Folha de São Paulo. Cotidiano. 01 ago. 1997. Disponível em:<http://www1.folha.uol.com.br/fsp/1997/8/01/ cotidiano/16. html.> Acessado em: 24/10/10

Ascher, Nelson. As faltas da educação. Folha de São Paulo. Ilustrada. 27 nov. 2006. Disponível em: <http://www1.folha.uol.com.br/fsp/ilustrad/fq2711200618.htm.> Acessado em: 26 nov. 2010. 
Assis, Toni. Arma em escola é comum, diz estudo. Folha de São Paulo. Cotidiano. 27 mar. 2006. Disponível em: <http://www1.folha.uol.com.br/fsp/cotidian/ff2703200618. htm.> Acessado em: 26 nov. 2010.

Athias, Gabriela. Escola é acusada de proibir "sem-uniforme". Folha de São Paulo. Cotidiano. 16 jun. 2002. Disponível em: <http://www1.folha.uol.com.br/fsp/cotidian /ff2304200230.htm.> Acessado em: 26 nov. 2010

ATHIAS, Gabriela. Escola pública cobra "pedágio" de aluno. Folha de São Paulo. Cotidiano. 23 jun. 2001. Disponível em: <http://www1.folha.uol.com.br/fsp/ cotidian/ff2306200101.htm.> Acessado em: 26 nov. 2010.

Athias, Gabriela. Escola terá liberdade para definir currículo. Folha de São Paulo. Cotidiano. 09 dez. 2001. Disponível em: <http://www1.folha.uol.com.br/fsp/cotidian/ ff0912200113.htm.> Acessado em: 26 nov. 2010.

AthiAs, Gabriela. Governos deixam Paraisópolis sem escola. Folha de São Paulo. Cotidiano. 23 abr. 2002. Disponível em: <http://www1.folha.uol.com.br/fsp/cotidian /ff1606200218.htm.> Acessado em: 26 nov. 2010.

Avaliação do ensino. Folha de São Paulo. Editorial. 07 dez. 2003. Disponível em: <http://www1.folha. uol.com.br/fsp/opiniao/fz0505200503.htm.> Acessado em: 26 nov. 2010.

Avancini, Marta. Aluno aprende menos em fim de ciclo. Folha de São Paulo. Cotidiano. 24 nov. 1999e. Disponível em: <http://www1.folha.uol.com.br/fsp/ cotidian/ff2411199924. htm.> Acessado em: 26 nov. 2010.

Avancini, Marta. De cada 6 trabalhadores, 1 fez curso médio. Folha de São Paulo. Cotidiano. 17 set. 1998b. Disponível em: <http://www1.folha.uol.com.br/fsp/cotidian /ff17099810.htm.> Acessado em: 26 nov. 2010.

Avancini, Marta. Educador responsabiliza pais e escolas por delinquência. Folha de São Paulo. Cotidiano. 10 mai. 1999d. Disponível em: <http://www1.folha.uol.com.br/ fsp/brasil/fc1005 9915.htm.> Acessado em: 26 nov. 2010.

Avancini, Marta. Ensino desperdiça $\mathrm{R} \$ 5,2$ bi em um ano. Folha de São Paulo. Cotidiano. 27 jul. 1998a. Disponível em: <http://www1.folha.uol.com.br/fsp/cotidian /ff27079801.htm.> Acessado em: 26 nov. 2010.

Avancini, Marta. Ensino deve se ligar à realidade. Folha de São Paulo. Cotidiano. 17 jan. 2000. Disponível em: <http://www1.folha.uol.com.br/fsp/cotidian/ff170120000 7.htm.> Acessado em: 13 abr. 2010.

Avancini, Marta. Escolaridade influencia a capacidade do pensamento. Folha de São Paulo. Cotidiano. 14 abr. 1999. Disponível em: <http://www1.folha.uol.com.br/fsp/coti dian/ff14049922. htm.> Acessado em: 26 nov. 2010.

Avancini, Marta. Estudo mostra desajuste do ensino básico. Folha de São Paulo. Cotidiano. 24 mar. 1999b. Disponível em: <http://www1.folha.uol.com.br/fsp/cotidian /ff24039923.htm.> Acessado em: 26 nov. 2010.

Avancini, Marta. Exclusão social é causa de violência nas escolas. Folha de São Paulo. Cotidiano. 09 ago. 1999. Disponível em: <http://www1.folha.uol.com.br/fsp/cotidian/ ff09089906.htm.> Acessado em: 26 nov. 2010. 
AvancIni, Marta. Medidas de baixo custo melhoram ensino, diz BID. Folha de São Paulo. Cotidiano. 12 abr. 1999c. Disponível em: <http://www1.folha.uol.com.br/fsp/ cotidian/ff1204990 5.htm.> Acessado em: 26 nov. 2010.

Avancini, Marta. Novo curso normal pretende aproximar teoria e prática. Folha de São Paulo. Cotidiano. 15 mar. 1999a. Disponível em: <http://www1.folha.uol.com.br/fsp/ cotidian/ff15039 904.htm.> Acessado em: 26 nov. 2010.

Avancini, Marta. Pai chegou ao limite de gasto escolar. Folha de São Paulo. Cotidiano. 15 dez.1997. Disponível em: <http://www1.folha.uol.com.br/fsp/cotidian /ff151201.htm.> Acessado em: 26 nov. 2010.

Azevedo, José Carlos de. Educação e mudanças essenciais. Folha de São Paulo. Opinião. 15 abr. 1998. Disponível em: <http://www1.folha.uol.com.br/fsp/opinião/fz 15049810.htm.> Acessado em: 26 nov. 2010.

BAHIA, Guilherme. Escola "condena" crianças pobres, afirma cientista. Folha de São Paulo. Brasil. 27 out. 2003. Disponível em: <http://www1.folha.uol.com.br/fsp/brasil/ fc2710200306.htm.> Acessado em: 26 nov. 2010.

BAPTISTA, Renata. Especialistas criticam uso de propaganda em uniforme escolar. Folha de São Paulo. Cotidiano. 01 set 2005. Disponível em: <http://www1.folha.uol. com.br/fsp/cotidian /ff0109200515.htm.> Acessado em: 26 nov. 2010.

BASSETTE, Fernanda. Fim das férias traz à tona sintomas de fobia escolar. Folha de São Paulo. Cotidiano. 31 jul. 2005. Disponível em: <http://www1.folha.uol.com.br/fsp/coti dian/ff3107200511.htm.> Acessado em: 26 nov. 2010.

BASSETTE, Fernanda. Internet em escola será controlada. Folha de São Paulo. Cotidiano. $10 \mathrm{dez}$. 2005. Disponível em: <http://www1.folha.uol.com.br/fsp/cotidian /ff1012200519.htm.> Acessado em: 26 nov. 2010.

Benatti, Luciana. Censo é ineficiente, dizem educadores. Folha de São Paulo. Cotidiano. 13 mai. 1997. Disponível em: <http://www1.folha.uol.com.br/fsp/1997/5/13/ cotidiano/53.html.> Acessado em: 26 nov. 2010.

BenAtTi, Luciana. Escolas de SP viram 'centros de diversão'. Folha de São Paulo. Cotidiano. 28 jul. 1997 Disponível em: <http://www1.folha.uol.com.br/fsp/cotidian/ff2 80728.htm.> Acessado em: 26 nov. 2010.

BenAtTi, Luciana. Pais serão responsáveis por evasão escolar. Folha de São Paulo. Cotidiano. 06 ago. 1997. Disponível em: <http://www1.folha.uol.com.br/fsp/cotidian/ ff060833.htm.> Acessado em: 26 nov. 2010.

BenAtTi, Luciana. Professor de segundo grau terá que fazer cursos de reciclagem. Folha de São Paulo. Cotidiano. 20 mai. 1997a. Disponível em: <http://www1.folha.uol. com.br/fsp/cotidian/ff200537.htm . Acessado em: 26 nov. 2010.

BenAtTi, Luciana. Professores criam grupos antidrogas. Folha de São Paulo. Cotidiano. 26 jun. 1997b. Disponível em: <http://www1.folha.uol.com.br/fsp/1997/6/26 /cotidiano/27.html.> Acessado em: 13 abr. 2010.

Bernardes, Betina. Aluno terá de entrar com 6 anos na escola. Folha de São Paulo. Cotidiano. 12 dez. 1997b. Disponível em: <http://www1.folha.uol.com.br/fsp/cotidian /ff121237.htm.> Acessado em: 24/10/2010. 
Bernardes, Betina. Começa hoje avaliação do ensino básico. Folha de São Paulo. Cotidiano. 27 out. 1997. Disponível em: <http://www1.folha.uol.com.br/fsp/1997/ 10/27/cotidiano/6.html.> Acessado em: 26 nov. 2010.

Bernardes, Betina. Conselho estuda ligar aulas ao cotidiano. Folha de São Paulo. Cotidiano. 31 jan. 1998. Disponível em: <http://www1.folha.uol.com.br/fsp/cotidian /ff31019829.htm.> Acessado em: 26 nov. 2010.

BERNARDES, Betina. Convênio com a Coca-Cola paga para estudante auxiliar ensino. Folha de São Paulo. Cotidiano. 20 ago. 1998. Disponível em: <http://www1.folha.uol. com.br/fsp/cotidian/ff20089834.htm.> Acessado em: 26 nov. 2010.

Bernardes, Betina. Falta recurso para custear ensino médio, diz conselho. Folha de São Paulo. Cotidiano. 06 nov. 1997a. Disponível em: <http://www1.folha.uol.com.br/ fsp/cotidian/ ff061132. htm.> Acessado em: 13 abr. 2010.

BERnARDES, Betina. Mudança do $2^{\circ}$ grau depende de bom gerenciamento escolar. Folha de São Paulo. Brasil. 07 jul. 1997. Disponível em: <http://www1.folha.uol.com.br/ fsp/1997/7/07/brasil/3.html.> Acessado em: 26 nov. 2010.

BERnARDES, Betina. Notas do Enem comprovam o fosso entre a educação de ricos e pobres. Folha de São Paulo. Cotidiano. 15 dez. 1999. Disponível em: <http://www1. folha.uol.com.br/fsp/ cotidian/ff1512199902.htm.> Acessado em: 26 nov. 2010.

Betto, Frei. A guerrilha carcerária. Folha de São Paulo. Cotidiano. 16 mai. 2006. Disponível em: <http://www1.folha.uol.com.br/fsp/cotidian/ff1605200647.htm.> Acessado em: 13 abr. 2010.

BiancARelli, Aureliano. "Expulsão" é regra na rede particular. Folha de São Paulo. Cotidiano. 01 dez. 2001. Disponível em: <http://www1.folha.uol.com.br/fsp/cotidian /ff0112200123.htm.> Acessado em: 26 nov. 2010.

BiAnCARELli, Aureliano. Disciplina faz alunos assumirem responsabilidades. Folha de São Paulo. Cotidiano. 7 fev. 1998. Disponível em: <http://www1.folha.uol.com.br/fsp/ cotidian/ ff07029805.htm.> Acessado em: 26 nov. 2010.

BiAnCARELl, Aureliano. Estudo mostra aumento da desigualdade. Folha de São Paulo. Cotidiano. 13 ago. 1999. Disponível em: <http://www1.folha.uol.com.br/fsp/cotidian/f f13089921. htm.> Acessado em: 26 nov. 2010.

BIANCARELLI, Aureliano. MEC proíbe a realização de vestibulinho nas escolas. Folha de São Paulo. Cotidiano. 13 nov. 2003. Disponível em: <http://www1.folha.uol.com.br /fsp/ cotidian/ff0712200323.htm.> Acessado em: 26 nov. 2010.

BocAto, Raquel. Escola é prioridade no orçamento doméstico. Folha de São Paulo. Caderno especial. 08 mar. 2005. Disponível em: <http://www1.folha.uol.com.br/fsp/ especial/ fj0803200519.htm.> Acessado em: 26 nov. 2010.

Bosi, Alfredo. O ponto cego do ensino público. Folha de São Paulo. Opinião. 09 mar. 1997. Disponível em: <http://www1.folha.uol.com.br/fsp/opiniao/fz090310.htm.> Acessado em: 24/10/10.

BRASIL, Katia. Com ameaça de prender os pais, promotor consegue zerar a evasão escolar. Folha de São Paulo. Cotidiano. 28 jun. 2002. Disponível em: <http://www1. folha.uol.com.br/fsp/ cotidian/ff2806200229.htm.> Acessado em: 26 nov. 2010. 
BRITO, Luísa. Escolas da prefeitura terão ensino religioso. Folha de São Paulo. Cotidiano. 04 jul. 2006. Disponível em: <http://www1.folha.uol.com.br/fsp/cotidian /ff0407200612.htm.> Acessado em: 26 nov. 2010.

Buarque, Cristovam. A revolução doce. Folha de São Paulo. Opinião. 22 dez. 2006. Disponível em: <http://www1.folha.uol.com.br/fsp/opiniao/fz2210200609.htm.> Acessado em: 24/10/10.

CAPriglione, Laura. Aluno aprende mal, mas aprova professor. Folha de São Paulo. Cotidiano. 19 jul. 2004. Disponível em: <http://www1.folha.uol.com.br/fsp/cotidian/ff1 907200401.htm.> Acessado em: 26 nov. 2010.

CAPriglione, Laura. Educação inova, mas sem avaliar aprendizado. Folha de São Paulo. Brasil. 30 out. 2004. Disponível em: <http://www1.folha.uol.com.br/fsp/Brasil/fc 3010200437.htm.> Acessado em: 26 nov. 2010.

Carvalho, Mario Cesar. Formação do professor precisa de mudança. Folha de São Paulo. Cotidiano. 31 out. 2004. Disponível em: <http://www1.folha.uol.com.br /fsp/cotidian/ ff3110200410.htm.> Acessado em: 26 nov. 2010.

CAVERSAN, Luiz. Brasil deve investir mais em curso noturno, recomenda Banco Mundial. Folha de São Paulo. Cotidiano. 26 out. 2000. Disponível em: <http://www1. folha.uol.com.br /fsp/cotidian/ff2610200028.htm.> Acessado em: 26 nov. 2010.

Ceneviva, Walter. São Paulo: o município. Folha de São Paulo. Cotidiano. 23 jan. 1999. Disponível em: <http://www1.folha.uol.com.br/fsp/cotidian/ff23019909.htm.> Acessado em: 24/10/10.

Ceolin, Patricia. Pai fica acampado em escola por vagas. Folha de São Paulo. Cotidiano. 31 dez. 1996. Disponível em: <http://www1.folha.uol.com.br/fsp/1996/12 /31/cotidiano/34.html.> Acessado em: 26 nov. 2010.

Chalita, Gabriel. Aprendizagem, ficção e vida real. Folha de São Paulo. Opinião. 09 fev. 2003. Disponível em: <http://www1.folha.uol.com.br/fsp/opiniao/fz09022003 09.htm.> Acessado em: 26 nov. 2010.

Chalita, Gabriel. Avaliação necessária. Folha de São Paulo. Opinião. 12 dez. 2005. Disponível em: <http://www1.folha.uol.com.br/fsp/opiniao/fz1212200509.htm.> Acessado em: 26 nov. 2010.

Chalita, Gabriel. Mensagem a quem professa o magistério. Folha de São Paulo. Opinião. 15 out. 2004. Disponível em: <http://www1.folha.uol.com.br/fsp/opiniao/fz1 510200409.htm.> Acessado em: 26 nov. 2010.

Chalita, Gabriel. O "Cinema Paradiso" e a volta às aulas. Folha de São Paulo. Opinião. 09 fev. 2004. Disponível em: <http://www1.folha.uol.com.br/fsp/opinião/fz0 902200410.htm.> Acessado em: 26 nov. 2010.

Chalita, Gabriel. O primeiro dia de aula. Folha de São Paulo. Opinião. 14 fev. 2005. Disponível em: <http://www1.folha.uol.com.br/fsp/opiniao/fz1402200509.htm.> Acessado em: 26 nov. 2010.

Chalita, Gabriel. Por uma educação poética. Folha de São Paulo. Opinião. 19 set. 2003. Disponível em: <http://www1.folha.uol.com.br/fsp/opiniao/fz1909200310.htm.> Acessado em: 26 nov. 2010. 
CHAves, Adriana. Diversidade social melhora a educação. Folha de São Paulo. Cotidiano. 29 fev. 2004. Disponível em: <http://www1.folha.uol.com.br/fsp/ cotidian/ff2902200401.htm.> Acessado em: 26 nov. 2010.

Chaves, Adriana. Dois mundos se encontram na mesma escola. Folha de São Paulo. Cotidiano. 29. fev. 2004. Disponível em: <http://www1.folha.uol.com.br/fsp/cotidian/ff 2902200402.htm.> Acessado em: 26 nov. 2010.

Christofoletti, Lilian. Prova é diagnóstico do ensino básico. Folha de São Paulo. Cotidiano. 22 out. 1999. Disponível em: <http://www1.folha.uol.com.br/fsp/ cotidian/ff2210199930.htm.> Acessado em: 26 nov. 2010.

CIDAdE-escola. Folha de São Paulo. Editorial. 18.jul.2005. Disponível em:<http://www1.folha.uol.com.br/fsp/opiniao/fz1807200503.htm.> Acessado em: 26 nov. 2010.

CiPOlA, Ari. Educação infantil deve ganhar programa. Folha de São Paulo. Cotidiano. 13 jul. 2000. Disponível em: <http://www1.folha.uol.com.br/fsp/cotidian/ff1307200020. htm.> Acessado em: 26 nov. 2010.

CoISSI, Juliana. Quadra vira sala de aula no interior. Folha de São Paulo. Cotidiano. 22 fev. 2006. Disponível em: <http://www1.folha.uol.com.br/fsp/cotidian/ff2202200620. htm.> Acessado em: 26 nov. 2010.

CollucCI, Cláudia. Auto-avaliação mediu qualidade de escola. Folha de São Paulo. Cotidiano. 05 jul. 2004. Disponível em: <http://www1.folha.uol.com.br/fsp/ cotidian/ff0507200401.htm.> Acessado em: 26 nov. 2010.

CollucCI, Cláudia. Cresce a inclusão escolar de deficientes. Folha de São Paulo. Cotidiano. 22 fev. 2004. Disponível em: <http://www1.folha.uol.com.br/fsp/cotidian /ff2202200415.htm.> Acessado em: 26 nov. 2010.

ColluCCI, Cláudia. Escolas de SP receberão kits sobre prevenção. Folha de São Paulo. Cotidiano. 19 ago. 2003. Disponível em: <http://www1.folha.uol.com.br/fsp/cotidian/ff 1908200316.htm.> Acessado em: 26 nov. 2010.

Collucci, Cláudia. Unesco quer que escola ensine a mediar conflitos. Folha de São Paulo. Cotidiano. 25 jul. 2005. Disponível em: <http://www1.folha.uol.com.br/fsp/coti dian/ff2507200515.htm.> Acessado em: 13 abr. 2010.

Constantino, Luciana. 1,4 milhão de jovens largam o ensino médio. Folha de São Paulo. Cotidiano. 24 mar. 2006. Disponível em: <http://www1.folha.uol.com.br/fsp/co tidian/ff2403200607. htm.> Acessado em: 13 abr. 2010.

Constantino, Luciana. 13\% dos estudantes de 10 a 12 anos já usaram drogas. Folha de São Paulo. Cotidiano. 01 jun. 2005. Disponível em: <http://www1.folha.uol.com.br/ fsp/cotidian/ ff0106200528.htm.> Acessado em: 26 nov. 2010.

CONSTANTino, Luciana. Avaliação da educação básica desnuda a carência do ensino. Folha de São Paulo. Folhateen. 28 abr. 2003. Disponível em: <http://www1.folha.uol. com.br/fsp/folhatee/fm2804200330.htm.> Acessado em: 26 nov. 2010.

Constantino, Luciana. Cristovam anuncia "provão" para professores. Folha de São Paulo. Cotidiano. 06 jun. 2003. Disponível em: <http://www1.folha.uol.com.br/fsp/cot idian/ff0606200306.htm.> Acessado em: 26 nov. 2010. 
Constantino, Luciana. Ensino público tem 33 escolas modelo. Folha de São Paulo. Cotidiano. 20.dez.2006. Disponível em:<http://www1.folha.uol.com.br/fsp/cotidian/ ff2012200610.htm.> Acessado em: 26 nov. 2010.

Constantino, Luciana. Escola deixa aluno vulnerável, diz UNESCO. Folha de São Paulo. Cotidiano. 28 abr. 2004. Disponível em: <http://www1.folha.uol.com.br/fsp/ cotidian/ ff2804200412.htm.> Acessado em: 26 nov. 2010.

Constantino, Luciana. Falta de professor pode afetar todo o país. Folha de São Paulo. Cotidiano. 04 mar. 2005. Disponível em: <http://www1.folha.uol.com.br/fsp/cotidian /ff0403200525.htm.> Acessado em: 26 nov. 2010.

Constantino, Luciana. Falta melhorar qualidade do ensino, diz Bird. Cotidiano. 22 mar 2003. Disponível em: <http://www1.folha.uol.com.br/fsp/cotidian/ff2203200308. htm.> Acessado em: 26 nov. 2010.

Constantino, Luciana. Gangue assusta escola, diz pesquisa. Folha de São Paulo. Cotidiano. 12 abr. 2005. Disponível em: <http://www1.folha.uol.com.br/fsp/cotidian /ff1204200514.htm.> Acessado em: 26 nov. 2010.

COnStantino, Luciana. Má qualidade da educação afeta futuro dos brasileiros. Folha de São Paulo. Folhateen. 17 mar 2003. Disponível em: <http://www1.folha.uol.com.br /fsp/opiniao/fz1803200307.htm.> Acessado em: 26 nov. 2010.

CONSTANTINO, Luciana. MEC quer disseminar no país modelo adotado por colégio com maior notas. Folha de São Paulo. Cotidiano. 28 set. 2006. Disponível em: <http://www 1.folha.uol.com.br/fsp/cotidian/ff2809200611.htm.> Acessado em: 26 nov. 2010.

CONSTANTINO, Luciana. MEC quer incluir na escola criança de seis anos de idade. Folha de São Paulo. Cotidiano. 24 mai 2003. Disponível em: <http://www1.folha.uol. com.br/fsp/cotidian/ff2405200310.htm.> Acessado em: 26 nov. 2010.

Constantino, Luciana. Meta inclui implantação do período integral. Folha de São Paulo. Cotidiano. 08 jun. 2003. Disponível em: <http://www1.folha.uol.com.br/fsp/ cotidian/ ff0806200302.htm.> Acessado em: 26 nov. 2010.

Constantino, Luciana. Metade dos pais diz haver briga em escola. Folha de São Paulo. Cotidiano. 24 mai. 2005. Disponível em: <http://www1.folha.uol.com.br/fsp/ cotidian/ ff2405200530.htm.> Acessado em: 26 nov. 2010.

CONSTANTINO, Luciana. Negros deixam a escola antes dos brancos, diz pesquisa. Folha de São Paulo. Cotidiano. 15 jul. 2003. Disponível em: <http://www1.folha.uol.com. br/fsp/cotidian/ ff1507200313.htm.> Acessado em: 26 nov. 2010.

Constantino, Luciana. Negros são apenas $33 \%$ na escola privada. Folha de São Paulo. Cotidiano. 28 jul 2006. Disponível em: <http://www1.folha.uol.com.br/fsp/cotidian/ff28 07200601.htm.> Acessado em: 26 nov. 2010.

Constantino, Luciana. Para o MEC, aprendizado é uma "tragédia". Folha de São Paulo. Cotidiano. 23 abr 2003. Disponível em: <http://www1.folha.uol.com.br/fsp/ cotidian/ff2304200301.htm.> Acessado em: 26 nov. 2010.

Constantino, Luciana. Pesquisa da Unesco quantifica desigualdade. Folha de São Paulo. Cotidiano. 30 abr 2003a. Disponível em: <http://www1.folha.uol.com.br/fsp/cot idian/ff30042 00310. htm.> Acessado em: 13 abr. 2010. 
Constantino, Luciana. Professor estuda mais, mas salário é baixo. Folha de São Paulo. Cotidiano. 16 out. 2003b. Disponível em: <http://www1.folha.uol.com.br/fsp/ cotidian/ff16102003 11.htm.> Acessado em: 26/11/2010

Constantino, Luciana. Professores e alunos criticam superlotação. Folha de São Paulo. Cotidiano. 22 ago 2006. Disponível em: <http://www1.folha.uol.com.br/fsp/ cotidian/ ff2208200618.htm.> Acessado em: 26 nov. 2010.

Constantino, Luciana. Só 59\% concluem o ensino fundamental. Folha de São Paulo. Cotidiano. 12 mar. 2003. Disponível em :<http://www1.folha.uol.com.br/fsp/cotidi an/ff1203200301.htm.> Acessado em: 26 nov. 2010.

CONTA difícil. Folha de São Paulo. Editorial. 04 mar 2003. Disponível em: <http://www1.folha.uol.com.br/fsp/opiniao/fz0403200302.htm.> Acessado em: 26 nov. 2010.

CONTRERAS, Javier. Escola municipal testa nova pedagogia. Folha de São Paulo. Cotidiano. 28 nov 2004. Disponível em: <http://www1.folha.uol.com.br/fsp/cotidian/ ff2811200407.htm.> Acessado em: 26 nov. 2010.

CorrêA, Sílvia. Exame reprovará alunos em fim de ciclo. Folha de São Paulo. Cotidiano. 14 nov. 2001. Disponível em: <http://www1.folha.uol.com.br/fsp/ cotidian/ff1411200106.htm.> Acessado em: 26 nov. 2010.

Cosso, Roberto. Lei obriga ensino de cultura afro. Folha de São Paulo. Cotidiano. 11 jan. 2003. Disponível em: <http://www1.folha.uol.com.br/fsp/cotidian/ff1101200312. htm.> Acessado em: 26 nov. 2010.

CRIME na escola. Folha de São Paulo. Editorial. 31 mar. 1997. Disponível em: <http://www1.folha.uol.com.br/fsp/1997/3/31/opiniao/3.html.> Acessado em: 26 nov. 2010.

DANTAS, Iuri. Aluno analfabeto põe avaliação em xeque. Folha de São Paulo. Cotidiano. 16 abr. 2002. Disponível em: <http://www1.folha.uol.com.br/fsp/cotidian/ ff1604200209.htm.> Acessado em: 26 nov. 2010.

DANTAS, Iuri. Verba para segurança nas escolas aumenta 9 vezes. Folha de São Paulo. Cotidiano. 11 mai. 2002. Disponível em: <http://www1.folha.uol.com.br/fsp/cotidian/f f1105200212.htm.> Acessado em: 26 nov. 2010.

Desastre no Enem. Folha de São Paulo. Editorial. 14 nov. 2002. Disponível em: <http://www1.folha.uol.com.br/fsp/opiniao/fz1411200203.htm.> Acessado em: 26 nov. 2010

Desigualdade escolar. Folha de São Paulo. Editorial. 05 mai. 2003. Disponível em: <http://www1.folha.uol.com.br/fsp/opiniao/fz0505200301.htm.> Acessado em: 26 nov. 2010 .

Desiguladade escolar. Folha de São Paulo. Editorial. 05 mai. 2003. Disponível em: <http://www1.folha.uol.com.br/fsp/opiniao/fz0505200301.htm.> Acessado em: 13 abr. 2010.

Detoni, Márcia. Mapa da mina para mães e pais angustiados. Folha de São Paulo. Equilíbrio. 16 ago. 2001. Disponível em: <http://www1.folha.uol.com.br/fsp/equilíbrio /eq1608200111. htm.> Acessado em: 13 abr. 2010. 
DiMENSTEIN, Gilberto. Quatro lições da professora Inês. Folha de São Paulo. Cotidiano. 16 jul. 2006. Disponível em: <http://www1.folha.uol.com.br/fsp/cotidian/ff160720 0628.htm.> Acessado em: 26 nov. 2010

Dimenstein, Gilberto. A escola que descobriu o espírito de Natal. Folha de São Paulo. Cotidiano. 26 dez. 2004. Disponível em: <http://www1.folha.uol.com.br/fsp/cotidian/ ff2612200412.htm.> Acessado em: 26 nov. 2010.

DiMENSTEIN, Gilberto. A melhor lição de uma escola. Folha de São Paulo. Cotidiano. 26 nov. 2006. Disponível em: <http://www1.folha.uol.com.br/fsp/cotidian/ff26112 00627.htm.> Acessado em: 26 nov. 2010.

Dimenstein, Gilberto. Ao mestre com porrada. Folha de São Paulo. Cotidiano. 03 jun. 2001. Disponível em: <http://www1.folha.uol.com.br/fsp/cotidian/ff0306200121.htm.> Acessado em: 26 nov. 2010.

DimensteIn, Gilberto. Dados revelam que pré-escolas e creches são depósitos humanos. Folha de São Paulo. Cotidiano. 24 out. 1999. Disponível em: <http://www1.folha.uol.com.br/ fsp/cotidian/ff2410199915.htm.> Acessado em: 26 nov. 2010.

DiMENSTEIN, Gilberto. É certo uma doméstica ganhar mais do que um professor? Folha de São Paulo. Cotidiano. 09 abr. 2006. Disponível em: <http://www1.folha.uol.com.br /fsp/cotidian/ff0904200633.htm.> Acessado em: 26 nov. 2010.

Dimenstein, Gilberto. Escola dá vida. Folha de São Paulo. Cotidiano. 19 jan. 2005. Disponível em: <http://www1.folha.uol.com.br/fsp/cotidian/ff1901200505.htm.> Acessado em: 26 nov. 2010.

DimensteIn, Gilberto. Escolas buscam professores na rua. Folha de São Paulo. Brasil. 01 set. 2000. Disponível em: <http://www1.folha.uol.com.br/fsp/brasil/fc0109200019. htm.> Acessado em: 26 nov. 2010.

DimensteIn, Gilberto. Estamos pagando o preço da ignorância. Folha de São Paulo. Cotidiano. 05 dez. 1999. Disponível em: <http://www1.folha.uol.com.br/fsp/cotidian /ff0512199921.htm.> Acessado em: 26 nov. 2010.

DimensteIn, Gilberto. Estudo avalia programa anti-repetência. Folha de São Paulo. Cotidiano. 18 mar. 1999. Disponível em: <http://www1.folha.uol.com.br/fsp/ cotidian/ff18039923.htm.> Acessado em: 26 nov. 2010.

Dimenstein, Gilberto. Faltam professores capacitados. Folha de São Paulo. Cotidiano. 29 out. 1999. Disponível em: <http://www1.folha.uol.com.br/fsp/cotidian/ff2910 199924.htm.> Acessado em: 26 nov. 2010.

Dimenstein, Gilberto. Feliz aniversário. Folha de São Paulo. Cotidiano. 23 ago. 2006. Disponível em: <http://www1.folha.uol.com.br/fsp/cotidian/ff2308200602.htm.> Acessado em: 26 nov. 2010.

Dimenstein, Gilberto. Lugar de estudante é na rua. Folha de São Paulo. Cotidiano. 31 ago. 2003. Disponível em: <http://www1.folha.uol.com.br/fsp/cotidian/ff3108200327 .htm.> Acessado em: 26 nov. 2010.

DiMENSTEIN, Gilberto. Mais educação, menos corrupção. Folha de São Paulo. Cotidiano. 10 jul 2005. Disponível em: <http://www1.folha.uol.com.br/fsp/cotidian/ ff1007200518.htm.> Acessado em: 26 nov. 2010. 
DIMENSTEIN, Gilberto. Marketing social: parcerias ajudam a melhorar educação. Folha de São Paulo. Cotidiano. 12. jun. 2000. Disponível em: <http://www1.folha.uol. com.br/fsp/cotidian/ff1206200020.htm.> Acessado em: 24/10/10.

DiMEnSteIn, Gilberto. Nada a comemorar. Folha de São Paulo. Mundo. 15 out. 1997. Disponível em: <http://www1.folha.uol.com.br/fsp/mundo/ft151004.htm.> Acessado em: 13 abr. 2010.

Dimenstein, Gilberto. Não existe criança de rua no Brasil. Folha de São Paulo. Cotidiano. 21 mar 1999. Disponível em: <http://www1.folha.uol.com.br/fsp/cotidian/ ff21039911.htm.> Acessado em: 26 nov. 2010.

Dimenstein, Gilberto. O futuro da educação está no hospital. Folha de São Paulo. Cotidiano. 07 dez. 2003. Disponível em: <http://www1.folha.uol.com.br/fsp/cotidian/ ff0712200323.htm.> Acessado em: 26 nov. 2010.

Dimenstein, Gilberto. O professor não é santo. Folha de São Paulo. Cotidiano. 23 mai. 1999. Disponível em: <http://www1.folha.uol.com.br/fsp/cotidian/ff23059924.htm.> Acessado em: 13 abr. 2010.

Dimenstein, Gilberto. O QI da cidade de São Paulo. Folha de São Paulo. Cotidiano. 23 jan. 2005. Disponível em: <http://www1.folha.uol.com.br/fsp/cotidian/ff2301200528. htm.> Acessado em: 13 abr. 2010.

Dimenstein, Gilberto. Para ministro, escola particular é "chata". Folha de São Paulo. Cotidiano. 29 nov. 2000. Disponível em: <http://www1.folha.uol.com.br/fsp/cotidian/ ff2911200010.htm.> Acessado em: 26 nov. 2010.

Dimenstein, Gilberto. Quatro lições da professora Inês. Folha de São Paulo. Cotidiano. 16 jul. 2006. Disponível em: <http://www1.folha.uol.com.br/fsp/cotidian/ff1607200628. htm.> Acessado em: 26 nov. 2010.

DiMENSTEIN, Gilberto. Repetência é coisa de pobre. Folha de São Paulo. Cotidiano. 18 abr. 2004. Disponível em: <http://www1.folha.uol.com.br/fsp/cotidian/ff1804200426. htm.> Acessado em: 13 abr. 2010.

Dimenstein, Gilberto. Salve-se quem quiser. Folha de São Paulo. Mundo. 15 jan. 1997. Disponível em: <http://www1.folha.uol.com.br/fsp/1997/1/15/mundo/6.html.> Acessado em: 13 abr. 2010.

DINIZ, Melissa. "É fácil conseguir drogas perto da escola". Folha de São Paulo. Cotidiano. 05 jul. 2001. Disponível em: <http://www1.folha.uol.com.br/fsp/cotidian /ff0507200102.htm.> Acessado em: 26 nov. 2010.

DinIZ, Melissa. Aumenta a violência na rede municipal. Folha de São Paulo. Cotidiano. 18 jan. 2001. Disponível em: <http://www1.folha.uol.com.br/fsp/cotidian/ff18012 00114.htm.> Acessado em: 26 nov. 2010.

DurAn, Sérgio. Socialites se opõem a fechamento de escola. Folha de São Paulo. Cotidiano. $26 \mathrm{dez}$ 2001. Disponível em: <http://www1.folha.uol.com.br/fsp/cotidian /ff2612200119.htm.> Acessado em: 26 nov. 2010.

EDUCAÇÃo como prioridade. Folha de São Paulo. Editorial 29 dez. 1997. Disponível em: <http://www1.folha.uol.com.br/fsp/1997/12/29/opiniao/2.html.> Acessado em: 28/11/10. 
EDUCAÇÃo desigual. Folha de São Paulo. Editorial. 22 nov. 2003. Disponível em: <http://www1.folha.uol.com.br/fsp/opiniao/fz2211200303.htm.> Acessado em: 26 nov. 2010.

EDUCAÇÃo na berlinda. Folha de São Paulo. Editorial. 06 dez. 2001. Disponível em: <http://www1.folha.uol.com.br/fsp/opiniao/fz0612200102.htm.> Acessado em: 26 nov. 2010 .

EduCAÇÃo vem do berço. Folha de São Paulo. Editorial. 02 jan. 1998. Disponível em: <http://www1.folha.uol.com.br/fsp/opiniao/fz020101.htm.> Acessado em: 26 nov. 2010 .

EscóssiA, Fernanda da. Pais adotam cooperativas educacionais. Folha de São Paulo. Cotidiano. 24 jul 1997. Disponível em: <http://www1.folha.uol.com.br/fsp/cotidian/ ff240743.htm.> Acessado em: 26 nov. 2010.

ETERNA repetição. Folha de São Paulo. Editorial 08 fev. 2002. Disponível em: <http://www1.folha.uol.com.br/fsp/opiniao/fz0802200203.htm.> Acessado em: 26 nov. 2010.

FACCIO, Liane. Saiba escolher o colégio certo. Folha de São Paulo. Caderno especial. 07 out 2001. Disponível em: <http://www1.folha.uol.com.br/fsp/especial/fj0710200101. htm.> Acessado em: 26 nov. 2010.

FALCÃo, Daniela . MEC gasta R\$ $480 \mathrm{mi}$ com micros escolares. Folha de São Paulo. Cotidiano. 23 fev. 1997. Disponível em: <http://www1.folha.uol.com.br/fsp/cotidian/ ff230211.htm.> Acessado em: 26 nov. 2010.

FALCÃO, Daniela. "Já pra Escola" recebe 126 mil inscrições para a $1^{a}$ série. Folha de São Paulo. Cotidiano. 14 out. 1999. Disponível em: <http://www1.folha.uol.com.br/ fsp/cotidian/ ff1410199921.htm.> Acessado em: 26 nov. 2010.

FAlCão, Daniela. 1 universitário 'vale' 17 alunos do $1^{\circ}$ grau. Folha de São Paulo. Cotidiano. 24 nov. 1998. Disponível em: <http://www1.folha.uol.com.br/fsp/cotidian/ ff24119801.htm.> Acessado em: 26 nov. 2010.

FALCÃo, Daniela. Alfabetização vai adotar temas urbanos. Folha de São Paulo. Cotidiano. 29 jul. 1999. Disponível em: <http://www1.folha.uol.com.br/fsp/cotidian/ ff29079914.htm.> Acessado em: 26 nov. 2010.

FALCão, Daniela. Ambiente escolar influencia rendimento. Folha de São Paulo. Cotidiano. 24 out.1 999. Disponível em: <http://www1.folha.uol.com.br/fsp/cotidian/f f2410199916.htm.> Acessado em: 26 nov. 2010.

FALCÃo, Daniela. 'Corrente' escolar tenta melhorar o ensino. Folha de São Paulo. 05 mai. 1997. Cotidiano. Disponível em: <http://www1.folha.uol.com.br/fsp/1997/5/05/ cotidiano/1.html.> Acessado em: 13 abr. 2010.

FAlCÃo, Daniela. Crescem matrículas entre $5^{\mathrm{a}}$ e $8^{\mathrm{a}}$ séries. Folha de São Paulo. Cotidiano. 29 set. 1999. Disponível em: <http://www1.folha.uol.com.br/fsp/cotidian /ff2909199915.htm.> Acessado em: 26 nov. 2010.

FALCÃo, Daniela. Decreto muda formação de professores. Folha de São Paulo. Cotidiano. 16 dez. 1999. Disponível em: <http://www1.folha.uol.com.br/fsp/cotidian/ ff1612199913.htm.> Acessado em: 26 nov. 2010. 
FALCÃO, Daniela. Estados mudam para reduzir repetência. Folha de São Paulo. Cotidiano. 4 dez. 1996. Disponível em: <http://www1.folha.uol.com.br/fsp/1996/12/04/ cotidiano/5.html.> Acessado em: 26 nov. 2010

FALCÃo, Daniela. Estudantes valorizam honestidade. Folha de São Paulo. Cotidiano. 15 dez. 1999. Disponível em: <http://www1.folha.uol.com.br/fsp/cotidian/ff1512199909. htm.> Acessado em: 26 nov. 2010.

FAlCÃo, Daniela. Matrícula do ensino médio cresce 11,5\%. Folha de São Paulo. Cotidiano. 16 set. 1999. Disponível em: <http://www1.folha.uol.com.br/fsp/cotidian/ff1 609199912.htm.> Acessado em: 26 nov. 2010.

FAlCão, Daniela. Pobre do Brasil vai menos à escola, diz BID. Folha de São Paulo. Cotidiano. 17 jul. 1998. Disponível em: <http://www1.folha.uol.com.br/fsp/cotidian/ff1 7079801.htm.> Acessado em: 26 nov. 2010.

FÁvero, Lavínia. Educadores dão receita da boa escola. Folha de São Paulo. Caderno especial. 07 out 2001. Disponível em: <http://www1.folha.uol.com.br/fsp/especial /fj0710200112.htm.> Acessado em: 26 nov. 2010.

FELINTO, Marilene. Bomba, repetência, a escola que funcionava. Folha de São Paulo. Cotidiano. 05 dez. 2000. Disponível em: <http://www1.folha.uol.com.br/fsp/cotidian /ff0512200005.htm.> Acessado em: 26 nov. 2010.

FERnANDES, Eli. Falta de vagas obriga alunos a ficar no pré. Folha de São Paulo. Cotidiano. 25 nov. 1999. Disponível em: <http://www1.folha.uol.com.br/fsp/cotidian/ ff2511199928.htm.> Acessado em: 26 nov. 2010.

Fernandes, Fernanda. Para educadores, dados escondem realidade. Folha de São Paulo. Cotidiano. 24 jun. 2004. Disponível em: <http://www1.folha.uol.com.br/fsp/ cotidian/ff2406200406.htm.> Acessado em: 26 nov. 2010.

FERnANDES, Kamila. Proposta de aulas sobre sexualidade é explorada por Moroni. Folha de São Paulo. Brasil. 14 out. 2004. Disponível em: <http://www1.folha.uol. com.br/fsp/brasil/fc1410200422.htm.> Acessado em: 26 nov. 2010.

FERRAZ, Octávio Motta. Envolver os pais e a comunidade na gestão da escola pública. Folha de São Paulo. Caderno Especial - Folha Treinamento. 24 jun. 2005. Disponível em: <http:// www1.folha.uol.com.br/folha/treinamento/educacao/te2406200553.shtml.> Acessado em: 13 abr. 2010.

FESTA é quase uma ilusão. Folha de São Paulo. Editorial. 07 set. 1998. Disponível em: <http://www1.folha.uol.com.br/fsp/cotidian/ff07099814.htm.> Acessado em: 23/10/2010.

Floresta, Cleide. $5^{\circ}$ Saeb testa hoje 360 mil estudantes em todo o país. Folha de São Paulo. Cotidiano. 25 out. 1999. Disponível em: <http://www1.folha.uol.com.br/ fsp/cotidian/ ff2510199904.htm.> Acessado em: 26 nov. 2010.

Floresta, Cleide. Aluno do ensino médio do país é regular. Folha de São Paulo. Cotidiano. 10 nov. 1999. Disponível em: <http://www1.folha.uol.com.br/fsp/cotidian /ff1011199920.htm.> Acessado em: 26 nov. 2010.

Floresta, Cleide. Escolas devem ser "pais" dos alunos. Folha de São Paulo. Cotidiano. 31 ago. 1999. Disponível em: <http://www1.folha.uol.com.br/fsp/cotidian/ ff31089922.htm.> Acessado em: 26 nov. 2010. 
Fortino, Leandro. Brigada antibullying. Folha de São Paulo. Cotidiano. 20 jun. 2005. Disponível em: <http://www1.folha.uol.com.br/fsp/folhatee/fm2006200515.htm.> Acessado em: 26 nov. 2010.

FrançA, William. Cai número de matrículas de $1^{\text {a }}$ a $4^{\text {a }}$ série. Folha de São Paulo. Cotidiano. 31 ago. 2001. Disponível em: <http://www1.folha.uol.com.br/fsp/cotidian/ ff3108200146.htm.> Acessado em: 26 nov. 2010.

FrançA, William. Tema entra no currículo da escola pública. Folha de São Paulo. Cotidiano. 06 jun. 2001. Disponível em: <http://www1.folha.uol.com.br/fsp/cotidian/ ff0606200125.htm.> Acessado em: 26 nov. 2010.

Freitas, Janio de. A culpa dos números. Folha de São Paulo. Brasil. 01 dez. 2000. Disponível em: <http://www1.folha.uol.com.br/fsp/brasil/fc0112200007.htm.> Acessado em: 26 nov. 2010.

GALlo, Ricardo. Educação aos pedaços: criança come em pé em escola de SP. Folha de São Paulo. Cotidiano. 16 mar. 2006. Disponível em: <http://www1.folha.uol.com.br /fsp/cotidian /ff1603200624.htm.> Acessado em: 26 nov. 2010.

GALlO, Ricardo. Educação em pedaços: mães ajudam na limpeza de escola estadual. Folha de São Paulo. Cotidiano. 12 abr. 2006. Disponível em: <http://www1 .folha.uol.com.br/fsp/cotidian /ff1204200617.htm.> Acessado em: 26 nov. 2010.

GALlO, Ricardo. Educação improvisada: escola estadual implanta rodízio de aulas. Folha de São Paulo. Cotidiano. 11 mar. 2006. Disponível em: <http://www1 .folha.uol.com.br/fsp/cotidian/ff1103200606.htm . Acessado em: 26 nov. 2010.

GEnRo, Tarso. As raízes da crise na educação básica. Folha de São Paulo. Opinião. 18 jan. 2005. Disponível em: <http://www1.folha.uol.com.br/fsp/opiniao/fz1801200509. htm.> Acessado em: 24/10/10.

GerChmann, Léo. Crianças do RS terão aulas contra racismo. Folha de São Paulo. Cotidiano. 23 dez. 1999. Disponível em: <http://www1.folha.uol.com.br/fsp/cotidian /ff2312199931.htm.> Acessado em: 26 nov. 2010.

GERHARDT, Rodrigo. Uma nova paisagem para a educação. Folha de São Paulo. Equilíbrio. 12 ago. 2004. Disponível em: <http://www1.folha.uol.com.br/fsp/equilibrio/ eq1208200407.htm.> Acessado em: 26 nov. 2010.

GoIs, Antônio. "Pai terceirizado" ajuda criança a estudar. Folha de São Paulo. Cotidiano. 28 mar. 2004. Disponível em: <http://www1.folha.uol.com.br/fsp/cotidian /ff2803200401.htm.> Acessado em: 26 nov. 2010.

GoIs, Antônio. "Racismo expulsa criança negra da escola". Folha de São Paulo. Cotidiano. 25 mar. 2002. Disponível em: <http://www1.folha.uol.com.br/fsp/cotidian /ff2503200218.htm.> Acessado em: 26 nov. 2010. (entrevista)

GoIs, Antônio. 48\% dos professores dão aula sem diploma. Folha de São Paulo. Cotidiano. 12 out. 2000. Disponível em: <http://www1.folha.uol.com.br/fsp/cotidian/ ff1210200001.htm.> Acessado em: 26 nov. 2010.

GoIs, Antônio. Ação conjunta de diretores e pais faz a diferença na escola. Folha de São Paulo. Cotidiano. 28 fev. 2000. Disponível em: <http://www1.folha.uol.com.br/ fsp/cotidian/ ff2802200008.htm.> Acessado em: 26 nov. 2010. 
GoIs, Antônio. Acesso à escola não impede trabalho na rua. Folha de São Paulo. Cotidiano. 25 jul. 2004. Disponível em: <http://www1.folha.uol.com.br/fsp/ cotidian/ff2507200412.htm.> Acessado em: 26 nov. 2010.

GoIs, Antônio. Aluno carente não afetou qualidade em escola de SP. Folha de São Paulo. Cotidiano. 03 dez. 2000. Disponível em: <http://www1.folha.uol.com.br/fsp/ cotidian/ ff0312200006.htm.> Acessado em: 26 nov. 2010.

GoIs, Antônio. Aluno da rede pública foge do vestibular. Folha de São Paulo. Cotidiano. 18 ago. 2002. Disponível em: <http://www1.folha.uol.com.br/fsp/cotidian/ ff1808200213.htm.> Acessado em: 26 nov. 2010.

GoIs, Antônio. Atraso escolar afeta 53\% dos adolescentes. Folha de São Paulo. Cotidiano. 10 mai. 2002. Disponível em: <http://www1.folha.uol.com.br/fsp/cotidian /ff1005200216.htm.> Acessado em: 26 nov. 2010.

GoIs, Antônio. Atraso escolar afeta mais os meninos. Folha de São Paulo. Cotidiano. 27 jun. 2003. Disponível em: <http://www1.folha.uol.com.br/fsp/cotidian/ff270620 0319.htm.> Acessado em: 26 nov. 2010.

GoIS, Antônio. Avanços na educação não aproximam pobres de ricos. Folha de São Paulo. Cotidiano. 21 out. 2002. Disponível em: <http://www1.folha.uol.com.br /fsp/brasil/fc2110200222. htm.> Acessado em: 26 nov. 2010.

GoIs, Antônio. Bancos estrangeiros vão ensinar diretores de escolas públicas a gastar melhor. Folha de São Paulo. Cotidiano. 12 mai. 2000. Disponível em: <http://www1.folha.uol.com.br/fsp/cotidian/ff1205200011.htm.> Acessado em: 13 abr. 2010.

GoIs, Antônio. Boa gestão melhora nota de aluno. Folha de São Paulo. Cotidiano. 18 set. 2005. Disponível em: <http://www1.folha.uol.com.br/fsp/cotidian/ff1809200513. htm.> Acessado em: 26 nov. 2010.

GoIs, Antônio. Brasil é campeão em aluno repetente. Folha de São Paulo. Cotidiano. 01 mar. 2000. Disponível em: <http://www1.folha.uol.com.br/fsp/cotidian/ff01032 00002.htm.> Acessado em: 26 nov. 2010.

GoIs, Antônio. Brasil fica em $72^{\circ}$ em ranking de educação. Folha de São Paulo. Cotidiano. 27 out. 2006. Disponível em: <http://www1.folha.uol.com.br/fsp/cotidian /ff2710200620.htm.> Acessado em: 13 abr. 2010.

GoIs, Antônio. Capacitação de diretor melhora nível escolar. Folha de São Paulo. Cotidiano. 28 dez. 2004. Disponível em: <http://www1.folha.uol.com.br/fsp/cotidian/ ff2812200406.htm.> Acessado em: 26 nov. 2010.

GoIs, Antônio. Elite brasileira perde em ranking do ensino. Folha de São Paulo. Cotidiano. 28 set. 2002. Disponível em: <http://www1.folha.uol.com.br/fsp/cotidian/ ff2809200201.htm.> Acessado em: 26 nov. 2010.

GoIS, Antônio. Elite ocupa até 1/4 das vagas na rede pública. Folha de São Paulo. Cotidiano. 01 ago. 2004. Disponível em: <http://www1.folha.uol.com.br/fsp/cotidian/ ff0108200402.htm.> Acessado em: 26 nov. 2010.

GoIs, Antônio. Emeis melhoram formação. Folha de São Paulo. Cotidiano. 12 jan. 2000. Disponível em:<http://www1.folha.uol.com.br/fsp/cotidian/ff1201200015.htm.> Acessado em: 26 nov. 2010. 
GoIs, Antônio. Ensino básico tem queda de qualidade. Folha de São Paulo. Cotidiano 22 nov. 2000. Disponível em: <http://www1.folha.uol.com.br/fsp/cotidian/ff22112 00020.htm.> Acessado em: 26 nov. 2010.

GoIs, Antônio. Ensino se massifica, mas perde qualidade. Folha de São Paulo. Cotidiano. 30 set. 2003. Disponível em: <http://www1.folha.uol.com.br/fsp/especial/ fj3009200313.htm.> Acessado em: 26 nov. 2010.

GoIs, Antônio. Escola despreparada afugenta alunos. Folha de São Paulo. Cotidiano. 26 mar. 2000. Disponível em: <http://www1.folha.uol.com.br/fsp/cotidian/ff2603200006. htm.> Acessado em: 26 nov. 2010.

GoIs, Antônio. Escola influencia o desempenho. Folha de São Paulo. Cotidiano. 06 dez. 2002. Disponível em: <http://www1.folha.uol.com.br/fsp/cotidian/ff0612200202. htm.> Acessado em: 26 nov. 2010.

GoIs, Antônio. Escola pública boa deve começar em casa. Folha de São Paulo. Cotidiano. 01 ago. 2004. Disponível em: <http://www1.folha.uol.com.br/fsp/cotidian/ ff0108200403.htm.> Acessado em: 26 nov. 2010.

GoIS, Antônio. Escola pública não se preparou para receber carente. Folha de São Paulo. Brasil. 27 nov. 2000. Disponível em: <http://www1.folha.uol.com.br/fsp/brasil/ fc2711200015.htm.> Acessado em: 26 nov. 2010.

GoIs, Antônio. Escola pública reprova mais que particular. Folha de São Paulo. Cotidiano. 29 jun. 2001. Disponível em: <http://www1.folha.uol.com.br/fsp/cotidian/ff 2906200111.htm.> Acessado em: 26 nov. 2010.

GoIS, Antônio. Escola tem programa de prevenção. Folha de São Paulo. Cotidiano. 19 jun. 2005. Disponível em: <http://www1.folha.uol.com.br/fsp/cotidian/ff1906200529. htm.> Acessado em: 26 nov. 2010.

GoIs, Antônio. Escolarização aumenta no país. Folha de São Paulo. Cotidiano. 09 mai. 2002. Disponível em:<http://www1.folha.uol.com.br/fsp/especial/fj0905200218.htm.> Acessado em: 13 abr. 2010.

GoIs, Antônio. Escolas ampliam integração de deficiente. Folha de São Paulo. Cotidiano. 02 jun. 2001. Disponível em: <http://www1.folha.uol.com.br/fsp/cotidian /ff0206200101.htm.> Acessado em: 26 nov. 2010.

GoIs, Antônio. Especialista português defende inovar sem copiar. Folha de São Paulo. Cotidiano. 22 out. 2006. Disponível em: <http://www1.folha.uol.com.br/fsp/cotidian/ff2 210200613.htm.> Acessado em: 26 nov. 2010.

GoIs, Antônio. Evasão aumenta em quatro anos. Folha de São Paulo. Cotidiano. 22 set. 2003. Disponível em: <http://www1.folha.uol.com.br/fsp/cotidian/ff2209200304.htm.> Acessado em: 13 abr. 2010.

GoIs, Antônio. Exame mostra queda de nota na $4^{\text {a }}$ série. Folha de São Paulo. Cotidiano. 06 dez. 2002. Disponível em: <http://www1.folha.uol.com.br/fsp/cotidian/ff061220020 1.htm.> Acessado em: 26 nov. 2010.

GoIs, Antônio. Expansão do ensino não reduz desigualdade. Folha de São Paulo. Cotidiano. 04 dez. 2002. Disponível em: <http://www1.folha.uol.com.br/fsp/cotidian /ff0412200215.htm.> Acessado em: 26 nov. 2010. 
GoIs, Antônio. Faltam vagas para 9,9 mil em pré-escolas. Folha de São Paulo. Cotidiano. 31 jan. 2001. Disponível em: <http://www1.folha.uol.com.br/fsp/cotidian/ ff3101200101.htm.> Acessado em: 26 nov. 2010.

GoIs, Antônio. Governo estimulou avaliação de alunos e ensino. Folha de São Paulo. Cotidiano. 21 out. 2002. Disponível em: <http://www1.folha.uol.com.br/fsp/brasil/fc 2110200221.htm.> Acessado em: 26 nov. 2010

GoIs, Antônio. Livros didáticos distorcem história do país. Folha de São Paulo. Cotidiano. 05 set. 2001. Disponível em: <http://www1.folha.uol.com.br/fsp/cotidian/ff 0509200126.htm.> Acessado em: 26 nov. 2010.

GoIs, Antônio. Má formação de professores é uma das explicações para desempenho. Folha de São Paulo. Cotidiano. 28 nov. 2000. Disponível em: <http://www1.folha.uol. com.br/fsp/ cotidian/ff 2811200002.htm.> Acessado em: 13 abr. 2010.

GoIs, Antônio. MEC anuncia projetos para formação de docente. Folha de São Paulo. Cotidiano. 28 nov. 2000. Disponível em: <http://www1.folha.uol.com.br/fsp/cotidian /ff2811200001.htm.> Acessado em: 13 abr. 2010.

GoIs, Antônio. Método de ensino não determina sucesso. Folha de São Paulo. Cotidiano. 03 abr. 2006. Disponível em: <http://www1.folha.uol.com.br/fsp/cotidian/ ff0304200601.htm.> Acessado em: 26 nov. 2010.

GoIs, Antônio. Ministro diz que esperava notas melhores. Folha de São Paulo. Brasil. 04 dez. 2000. Disponível em: <http://www1.folha.uol.com.br/fsp/brasil/fc0412200015. htm.> Acessado em: 26 nov. 2010.

GoIs, Antônio. Número de estudantes é recorde; desigualdade na educação aumenta. Folha de São Paulo. Cotidiano. 19 dez. 2002. Disponível em: <http://www1.folha.uol. com.br/ fsp/especial/fj1912200228.htm.> Acessado em: 26 nov. 2010.

GoIs, Antônio. Pai e professor culpam aluno por repetência. Folha de São Paulo. Cotidiano. 30 mar. 2002. Disponível em: <http://www1.folha.uol.com.br/fsp/cotidian /ff3003200201.htm.> Acessado em: 26 nov. 2010.

GoIS, Antônio. País desperdiça pequenos "gênios". Folha de São Paulo. Cotidiano. 26 mar. 2000. Disponível em: <http://www1.folha.uol.com.br/fsp/cotidian/ff2603200001. htm.> Acessado em: 26 nov. 2010.

GoIs, Antônio. Para MEC, é preciso cumprimentar colégio e professor. Folha de São Paulo. Brasil. 27 nov. 2000. Disponível em: <http://www1.folha.uol.com.br/fsp/brasil/ fc2711200017.htm.> Acessado em: 26 nov. 2010.

GoIs, Antônio. Para ministro, repetência é o pior para aluno. Folha de São Paulo. Cotidiano. 29 set. 2000. Disponível em: <http://www1.folha.uol.com.br/fsp/cotidian/ ff2909200005.htm.> Acessado em: 26 nov. 2010.

GoIs, Antônio. Piora qualidade do ensino nas particulares. Folha de São Paulo. Cotidiano. 28 nov. 2000. Disponível em: <http://www1.folha.uol.com.br/fsp/cotidian/ ff2811200001.htm.> Acessado em: 26 nov. 2010.

GoIs, Antônio. Político escolhe $60 \%$ dos diretores de escola. Folha de São Paulo. Cotidiano. 18 set. 2005. Disponível em: <http://www1.folha.uol.com.br/fsp/opiniao/ fz0410200507.htm.> Acessado em: 26 nov. 2010. 
GoIs, Antônio. Preconceito afeta desempenho na escola. Folha de São Paulo. Cotidiano. 18 mai. 2003. Disponível em: <http://www1.folha.uol.com.br/fsp/cotidian/ ff1805200309.htm.> Acessado em: 26 nov. 2010.

GoIs, Antônio. Repetência no $1^{\circ}$ ano continua em 40\%. Folha de São Paulo. Cotidiano. 08 set. 2000. Disponível em: <http://www1.folha.uol.com.br/fsp/cotidian/ff08092 00002.htm.> Acessado em: 26 nov. 2010.

GoIs, Antônio. Repetência no ensino médio atinge um em cada cinco alunos. Folha de São Paulo. Folhateen. 29 set. 2003. Disponível em: <http://www1.folha.uol.com.br/fsp/ folhatee/fm2909200324.htm.> Acessado em: 26 nov. 2010.

GoIs, Antônio. Repetência volta a crescer no ensino médio. Folha de São Paulo. Cotidiano. 22 set. 2003. Disponível em: <http://www1.folha.uol.com.br/fsp/cotidian/ff2 209200301.htm.> Acessado em: 26 nov. 2010.

GoIS, Antônio. Sistema de ciclos não influi no aproveitamento dos estudantes. Folha de São Paulo. Cotidiano. 06 dez. 2002. Disponível em: <http://www1.folha.uol.com.br /fsp/cotidian /ff0612200204.htm.> Acessado em: 26 nov. 2010.

GoIs, Antônio. Site ajudará a fiscalizar qualidade de escola. Folha de São Paulo. Cotidiano. 26 out. 2000. Disponível em: <http://www1.folha.uol.com.br/fsp/cotidian/ ff2610200028.htm.> Acessado em: 26 nov. 2010.

GoIS, Antônio. Só 1/3 do ensino particular é adequado. Folha de São Paulo. Cotidiano. 28 jun. 2004. Disponível em: <http://www1.folha.uol.com.br/fsp/cotidian/ff2806200 401.htm.> Acessado em: 26 nov. 2010.

GoIs, Antônio. Um terço dos analfabetos já foi à escola. Folha de São Paulo. Cotidiano. 22 dez. 2003. Disponível em: <http://www1.folha.uol.com.br/fsp/cotidian/ff22122 00301.htm.> Acessado em: 26 nov. 2010.

Gomes, Fabrício Freire. Teto de "escola de lata" atinge $60^{\circ}$ C. Folha de São Paulo. Cotidiano. 18 out. 2005. Disponível em: <http://www1.folha.uol.com.br/fsp/cotidian/ ff1810200521.htm.> Acessado em: 26 nov. 2010.

GrAJEW, Oded. Educação para a cidadania. Folha de São Paulo. Opinião. 16 jan. 1997. Disponível em: <http://www1.folha.uol.com.br/fsp/1997/1/16/opiniao/8.html.> Acessado em: 13 abr. 2010.

Grossi, Esther Pilar. Educação e mercado. Folha de São Paulo. Cotidiano. 30 mar. 1998. Disponível em: <http://www1.folha.uol.com.br/fsp/cotidian/ff30039809.htm.> Acessado em: 26 nov. 2010.

Guelli, Paulo López. Escolas terão de oferecer aula de espanhol. Folha de São Paulo. Cotidiano. 06 ago. 2005. Disponível em: <http://www1.folha.uol.com.br/fsp/cotidian/ ff0608200522.htm.> Acessado em: 26 nov. 2010.

HAdDAd, Fernando. Educação básica. Folha de São Paulo. Opinião. 09 jul. 2006. Disponível em: <http://www1.folha.uol.com.br/fsp/opiniao/fz0907200608.htm.> Acessado em: 26 nov. 2010.

HAdDAd, Fernando. Educação e avaliação. Folha de São Paulo. Opinião. 20 nov. 2005. Disponível em: <http://www1.folha.uol.com.br/fsp/opiniao/fz2011200508.htm.> Acessado em: 26 nov. 2010. 
HARNIK, Simone. Escolas buscam métodos ousados para educação. Folha de São Paulo. Cotidiano. 22 out. 2006. Disponível em: <http://www1.folha.uol.com.br/fsp/cotidian/ ff2210200611.htm.> Acessado em: 26 nov. 2010.

HARNIK, Simone. Projetos diminuíram falta dos professores e indisciplina. Folha de São Paulo. Cotidiano. 22 out. 2006. Disponível em: <http://www1.folha.uol.com.br/fsp/ cotidian/ff2210200612.htm.> Acessado em: 26 nov. 2010.

IIzUKA, Roberto. Casos crescem no país. Folha de São Paulo. Mais. 20 abr. 1997. Disponível em: <http://www1.folha.uol.com.br/fsp/mais/fs200408.htm.> Acessado em: 26 nov. 2010

IoschPe, Gustavo. Essas bestas estudantis. Folha de São Paulo. Folhateen. 20 dez 1998. Disponível em: <http://www1.folha.uol.com.br/fsp/folhatee/fm07129814.htm.> Acessado em: 13 abr. 2010.

IOSCHPE, Gustavo. Por que a escola não serve pra (quase) nada. Folha de São Paulo. Folhateen. 01 mai. 2000. Disponível em: <http://www1.folha.uol.com.br/fsp/folhatee /fm0105200022.htm.> Acessado em: 26 nov. 2010.

IoschPe, Gustavo. Por uma educação de resultados. Folha de São Paulo. Opinião. 07 fev. 2005. Disponível em: <http://www1.folha.uol.com.br/fsp/opiniao/fz0702200510. htm.> Acessado em: 13 abr. 2010.

Jorge, Miguel. A nota baixa do ensino médio. Folha de São Paulo. Opinião. 20 nov. 2002. Disponível em: <http://www1.folha.uol.com.br/fsp/opiniao/fz2011200209.htm.> Acessado em: 26/11/2010.

Kormann, Alessandra. A portas fechadas. Folha de São Paulo. Folhateen. 18 abr. 2005. Disponível em: <http://www1.folha.uol.com.br/fsp/folhatee/fm1804200503.htm.> Acessado em: 26 nov. 2010.

Kormann, Alessandra. Peso de aluno pobre no Saeb divide opiniões. Folha de São Paulo. Cotidiano. 07 dez. 2002. Disponível em: <http://www1.folha.uol.com.br/fsp/ cotidian/ ff0712200212.htm.> Acessado em: 26 nov. 2010.

LAGE, Amarílis. MEC quer induzir formação de docente. Folha de São Paulo. Cotidiano. 14 out. 2003. Disponível em: <http://www1.folha.uol.com.br/fsp/cotidian /ff1311200329.htm.> Acessado em: 26 nov. 2010.

LAMBERT, Priscila. Educadores defendem reforço escolar. Folha de São Paulo. Cotidiano. 20 out. 1997. Disponível em: <http://www1.folha.uol.com.br/fsp/cotidian/ ff201006.htm.> Acessado em: 26 nov. 2010.

LAMBERT, Priscila. Escolas integram ou marginalizam seus alunos. Folha de São Paulo. Cotidiano. 27 out. 1999. Disponível em: <http://www1.folha.uol.com.br/fsp/cotidian/ ff2710199918.htm.> Acessado em: 26 nov. 2010.

LeITE, Pedro Dias. Investir em escola é evitar crime, diz Lula. Folha de São Paulo. Cotidiano. 29 dez. 2005. Disponível em: <http://www1.folha.uol.com.br/fsp/ cotidian/ff2912200523.htm.> Acessado em: 26 nov. 2010.

LimA, Bruno. Apenas 36\% dos alunos farão o Saresp. Folha de São Paulo. Cotidiano. 27 nov. 2002. Disponível em: <http://www1.folha.uol.com.br/fsp/cotidian/ff271120 0219.htm.> Acessado em: 26 nov. 2010. 
LIMA, Bruno. Especialistas criticam sistema que acabou com a repetência. Folha de São Paulo. Folhateen. 06 jan. 2003. Disponível em: <http://www1.folha.uol.com.br/fsp/ folhatee/fm0601200323.htm.> Acessado em: 26 nov. 2010.

LIMA, Bruno. Universidade rejeita modelo do PSDB em SP. Folha de São Paulo. Cotidiano. 02 jan. 2003. Disponível em: <http://www1.folha.uol.com.br/fsp/cotidian /ff0201200301.htm.> Acessado em: 26 nov. 2010.

LiNHARES, Juliana. Escolas públicas oferecem cardápio balanceado. Folha de São Paulo. Folhateen. 20 ago. 2001. Disponível em: <http://www1.folha.uol.com.br/fsp/ folhatee/fm2008200110.htm.> Acessado em: 26 nov. 2010.

Lo PRETE, Renata. 264 mil alunos terão de fazer recuperação em janeiro. Folha de São Paulo. Cotidiano. 18 dez. 2001. Disponível em: <http://www1.folha.uol.com.br/fsp/ cotidian /ff1812200118.htm.> Acessado em: 26 nov. 2010.

Lo Prete, Renata. Matemática é tormento para estudantes. Folha de São Paulo. Cotidiano. 04 nov. 2001. Disponível em: <http://www1.folha.uol.com.br/fsp/cotidian /ff0411200102.htm.> Acessado em: 26 nov. 2010.

Lo Prete, Renata. Reduzir a evasão qualifica escola. Folha de São Paulo. Cotidiano. 25 out. 2001. Disponível em: <http://www1.folha.uol.com.br/fsp/cotidian/ff251020 0121.htm.> Acessado em: 26 nov. 2010.

LONGMAN, Gabriela. Melhorar a infra-estrutura e adequar os espaços escolares à aprendizagem. Folha de São Paulo. Caderno Especial. 24 jun. 2005. Disponível em: <http://www1.folha.uol.com.br/folha/treinamento/educacao/te2406200552.shtml.>

Acessado em: 13 abr. 2010.

Macedo, Lino de. O lugar da escola. Folha de São Paulo. Caderno Especial. 07 ago. 1997. Disponível em: <http://www1.folha.uol.com.br/fs...7/8/07/cadernoespecial/11 .htm.> Acessado em: 26 nov. 2010.

MAIS alunos. Folha de São Paulo. Editorial. 9 fev. 1997. Disponível em: <http://www1.folha.uol.com.br/fsp/opiniao/fz090203.htm.> Acessado em: 26 nov. 2010.

MAIS tempo na escola. Folha de São Paulo. Editorial. 18 ago. 2006. Disponível em: <http://www1.folha.uol.com.br/fsp/opiniao/fz0203200003.htm.> Acessado em: 26 nov. 2010.

MARIA, Estanislau. Mais escolas terão almoço e jantar. Folha de São Paulo. Cotidiano. 19. jul. 2001. Disponível em: <http://www1.folha.uol.com.br/fsp/cotidian/ff19072 00125.htm.> Acessado em: 26 nov. 2010.

MARques, Jairo. Alunos da rede pública têm atraso maior. Folha de São Paulo. Cotidiano. 21 dez. 2002. Disponível em: <http://www1.folha.uol.com.br/fsp/cotidian /ff2112200205.htm.> Acessado em: 26 nov. 2010.

MARTinez, Mariana. Escola na zona leste faz rodízio de estudantes. Folha de São Paulo. Cotidiano. 20 fev. 2006. Disponível em: <http://www1.folha.uol.com.br/fsp/ cotidian/ff2002200610.htm.> Acessado em: 26 nov. 2010.

Matemática moderna. Folha de São Paulo. Editorial. 06 nov. 2001. Disponível em: <http://www1.folha.uol.com.br/fsp/opiniao/fz0611200103.htm.> Acessado em: 26 nov. 2010 . 
Mautone, Silvana. Seguro é uma das opções para garantir os estudos. Folha de São Paulo. Folhainvest. 05 fev. 2001. Disponível em: <http://www1.folha.uol.com.br/fsp/ invest/in0502200108.htm.> Acessado em: 26 nov. 2010.

Medaglia, Júlio. Cultura no banco escolar. Folha de São Paulo. Opinião. 13 jun. 1997. Disponível em: <http://www1.folha.uol.com.br/fsp/opiniao/fz130610.htm.> Acessado em: 26 nov. 2010.

Melhorar o ensino. Folha de São Paulo. Editorial. 27 mai. 2002. Disponível em: <http://www1.folha.uol.com.br/fsp/opiniao/fz2705200202.htm.> Acessado em: 26 nov. 2010.

Mello, Guiomar Namo de. A escola e a estrada da informação. Folha de São Paulo. Opinião. 16 out. 1998. Disponível em: <http://www1.folha.uol.com.br/fsp/opiniao/fz1 6109809.htm.> Acessado em: 26 nov. 2010.

Mello, Guiomar Namo de. Corações informados, cabeças feitas. Folha de São Paulo. Opinião. 02 ago. 1999. Disponível em: <http://www1.folha.uol.com.br/fsp/opiniao/fz0 2089910.htm.> Acessado em: 26 nov. 2010.

MenA, Fernanda. "Escola não expande valores humanos". Folha de São Paulo. Cotidiano. 01 ago. 2004. Disponível em: <http://www1.folha.uol.com.br/fsp/cotidian /ff0108200402.htm.> Acessado em: 26 nov. 2010.

MenA, Fernanda. 48\% dos "sem-estudo" quer voltar à escola. Folha de São Paulo. Cotidiano. 12 dez. 2004. Disponível em: <http://www1.folha.uol.com.br/fsp/cotidian/ff 1212200424.htm.> Acessado em: 26 nov. 2010.

MenA, Fernanda. Alunos brasileiros ficam em último lugar em ranking de educação. Folha de São Paulo. Folhateen. 10 dez. 2001. Disponível em: <http://www1.folha.uol. com.br/fsp/folhatee/fm1012200116.htm.> Acessado em: 26 nov. 2010.

MEnA, Fernanda. Colégio "expulsa alunos", afirma autora de estudo. Folha de São Paulo. Cotidiano. 05 jan. 2005. Disponível em: <http://www1.folha.uol.com.br/fsp/ cotidian/ ff0501200502.htm.> Acessado em: 26 nov. 2010.

MenA, Fernanda. Coordenadora do Estado propôs criação de creches para atender jovens mães. Folha de São Paulo. Cotidiano. 05.jan.2005. Disponível em: $<$ http://www1.folha.uol.com.br/fsp/cotidian/ff0501200503.htm. $>$ Acessado em: 24/10/10.

MenA, Fernanda. Inclusão exige capacitar os professores. Folha de São Paulo. Cotidiano. 22.fev.2004. Disponível em:<http://www1.folha.uol.com.br/fsp/cotidian/ff2202200416.htm.> Acessado em: 26 nov. 2010.

MEnA, Fernanda. Professores apontam violência nas escolas. Folha de São Paulo. Cotidiano. 30.ago.2004. Disponível em:<http://www1.folha.uol.com.br/fsp/cotidian/ ff3008200 417.htm.> Acessado em: 13 abr. 2010.

MENA, Fernanda. Projeto estimula criança a opinar sobre a gestão. Folha de São Paulo. Cotidiano. 31.mar.2004. Disponível em:<http://www1.folha.uol.com.br/fsp/cotidian/ ff3103200419.htm.> Acessado em: 26 nov. 2010.

MENA, Fernanda. Tolerância zero. Folha de São Paulo. Folhateen. 10.dez.2001. Disponível em:<http://www1.folha.uol.com.br/fsp/folhatee/fm1012200111.htm.> Acessado em: 26 nov. 2010. 
Momm, Thiago. Atualização de docentes precisa ser facilitada. Folha de São Paulo. Cotidiano. 24 set. 2006. Disponível em: <http://www1.folha.uol.com.br/fsp/cotidian/ff2 409200628.htm.> Acessado em: 26 nov. 2010.

Moraes, Antônio Erminio de. Ajude a nação estudando muito. Folha de São Paulo. Opinião. 05 jan. 2003. Disponível em: <http://www1.folha.uol.com.br/fsp/opiniao/ fz0501200306.htm.> Acessado em: 26 nov. 2010.

Moraes, Antônio Ermírio de. A enorme deficiência do nosso ensino. Folha de São Paulo. Opinião. 12 jun. 2005. Disponível em: <http://www1.folha.uol.com.br/fsp/ opiniao/fz1206200507.htm.> Acessado em: 26 nov. 2010.

MoRAES, Antônio Ermírio de. Educação: a prioridade mais importante de nosso país. Folha de São Paulo. Opinião. 08 jan. 2006. Disponível em: <http://www1.folha.uol. com.br/fsp/opiniao/ fz0801200606.htm.> Acessado em: 26 nov. 2010.

MORAES, Antônio Ermírio de. Educação: triste transição da qualidade para a quantidade. Folha de São Paulo. Opinião. 14 jan. 2001. Disponível em: <http://www1.folha.uol.com.br/fsp/opiniao/fz1401200106.htm.> Acessado em: 26 nov. 2010.

Moraes, Antônio Ermírio de. O provão e a competição entre escolas. Folha de São Paulo. Opinião. 14 jun. 1998. Disponível em: <http://www1.folha.uol.com.br /fsp/opiniao/fz14069806.htm.> Acessado em: 13 abr. 2010.

Moraes, Antônio Ermírio de. Professor esquecido é juventude fracassada. Folha de São Paulo. Opinião. 18 jan. 2004. Disponível em: <http://www1.folha.uol.com.br/fsp/ opiniao/fz18012004 06.htm.> Acessado em: 13 abr. 2010.

Moraes, Antônio Ermírio de. Um exemplo a ser seguido por todo o Brasil. Folha de São Paulo. Opinião. 28 nov. 2004. Disponível em: <http://www1.folha.uol.com.br/fsp/ opiniao/fz2811200406.htm.> Acessado em: 26 nov. 2010.

NARDELli, Fernanda. Formação de professores está melhor. Folha de São Paulo. Cotidiano. 30 ago. 2002. Disponível em:<http://www1.folha.uol.com.br/fsp/cotidian/ ff3008200208.htm.> Acessado em: 26 nov. 2010.

NASSIF,Luís. Abaixo a escola! Folha de São Paulo. Dinheiro. 16 fev. 1997. Disponível em: <http://www1.folha.uol.com.br/fsp/dinheiro/fi160208.htm.> Acessado em: 26 nov. 2010 .

NAZARETH, Rita. ABC financeiro deve ser ensinado na sala de aula. Folha de São Paulo. Folhainvest. 22 fev. 1999. Disponível em: <http://www1.folha.uol.com.br/fsp/ invest/in22029918.htm.> Acessado em: 26 nov. 2010.

NEM para gari. Folha de São Paulo. Editorial. 19 nov. 2002. Disponível em: <http://www1.folha.uol.com.br/fsp/opiniao/fz1911200202.htm.> Acessado em: 26 nov. 2010.

Nicoletti, André. Ensino básico é avaliado pelo Saeb. Folha de São Paulo. Cotidiano. 25 ago. 2002. Disponível em: <http://www1.folha.uol.com.br/fsp/cotidian/ff2508 200220.htm.> Acessado em: 26 nov. 2010.

NISKIER, Arnaldo. A educação religiosa nas escolas. Folha de São Paulo. Opinião. 17 mai. 2006. Disponível em: <http://www1.folha.uol.com.br/fsp/opiniao/fz170520 0610.htm.> Acessado em: 26 nov. 2010. 
NisKIER, Arnaldo. A hora das pedagogias variadas. Folha de São Paulo. Opinião. 04 set. 2006. Disponível em: <http://www1.folha.uol.com.br/fsp/opiniao/fz040920 0609.htm.> Acessado em: 26 nov. 2010.

NISKIER, Arnaldo. Droga na escola. Folha de São Paulo. Opinião. 28 set. 2001. Disponível em: <http://www1.folha.uol.com.br/fsp/opiniao/fz2809200109.htm.> Acessado em: 26 nov. 2010.

NISKIER, Arnaldo. Mentes brilhantes e educação caótica. Folha de São Paulo. Opinião. 24 mai. 2002. Disponível em: <http://www1.folha.uol.com.br/fsp/opiniao/fz2405 200210.htm.> Acessado em: 13 abr. 2010.

NiSKIER, Arnaldo. Os jovens e a leitura. Folha de São Paulo. Opinião. 19 mar. 2003. Disponível em: <http://www1.folha.uol.com.br/fsp/opiniao/fz1903200310.htm.> Acessado em: 26 nov. 2010.

NiskiER, Arnaldo. Qual é o futuro do magistério? Folha de São Paulo. Opinião. 23 fev. 2001. Disponível em: <http://www1.folha.uol.com.br/fsp/opiniao/fz2302200109.htm.> Acessado em: 26 nov. 2010.

Odebrecht, Emílio. Educação e trabalho. Folha de São Paulo. Opinião. 10 mar. 2006. Disponível em: <http://www1.folha.uol.com.br/fsp/opiniao/fz1603200609.htm.> Acessado em: 13 abr. 2010.

OliveIRA, Eduardo de. Jovens resistem a mudanças em SC. Folha de São Paulo. Cotidiano. 14 jan. 2005. Disponível em: <http://www1.folha.uol.com.br/fsp/cotidian/ ff1401200502.htm.> Acessado em: 26 nov. 2010.

OliveIRA, Marcelo. Depressão leva crianças ao suicídio. Folha de São Paulo. Cotidiano. 29 mar. 1998. Disponível em: <http://www1.folha.uol.com.br/fsp /cotidian/ff29039801.htm.> Acessado em: 26 nov. 2010.

Oliveira, Marcelo. Doença pode afetar $20 \%$ de estudantes. Folha de São Paulo. Cotidiano. 29 mar. 1998. Disponível em: <http://www1.folha.uol.com.br/fsp/cotidian/ ff29039805.htm.> Acessado em: 26 nov. 2010.

Oliveira, Marcelo. Professor de $1^{\circ}$ grau precisa de reciclagem. Folha de São Paulo. Cotidiano. 11 abr. 1997. Disponível em: <http://www1.folha.uol.com.br/fsp/1997/4/11/ cotidiano/47.html.> Acessado em: 26 nov. 2010.

Oliveira, Marcelo. Saúde mental deve ser discutida na escola. Folha de São Paulo. Cotidiano. 30 mar. 1998. Disponível em: <http://www1.folha.uol.com.br/fsp/cotidian/ ff30039810.htm.> Acessado em: 13 abr. 2010.

Ornaghi, Tiago. Professora nega ter deixado aluno de castigo. Folha de São Paulo. Cotidiano. 18 nov. 2004. Disponível em: <http://www1.folha.uol.com.br/fsp/cotidian/ ff1811200416.htm.> Acessado em: 26 nov. 2010.

PARAgUaSsú, Lisandra. Atraso escolar atinge 41,7\% dos alunos. Folha de São Paulo. Cotidiano. 28 jun. 2001. Disponível em: <http://www1.folha.uol.com.br/fsp/cotidian/ ff2806200116.htm.> Acessado em: 26 nov. 2010.

PARAgUASSÚ, Lisandra. Comportamento muda depois de aula sobre Aids. Folha de São Paulo. Cotidiano. 05 jul. 2001 Disponível em: <http://www1.folha.uol.com.br/fsp/ cotidian/ff0507200103.htm.> Acessado em: 26 nov. 2010. 
PARAgUASSÚ, Lisandra. Rede privada concentra computadores. Folha de São Paulo. Cotidiano. 28 jun. 2001. Disponível em: <http://www1.folha.uol.com.br/fsp/cotidian/ ff2806200116.htm.> Acessado em: 13 abr. 2010.

PeiXoto, Paulo. Escolas vão ensinar a evitar drogas em Minas. Folha de São Paulo. Cotidiano. 03 dez. 2000. Disponível em: <http://www1.folha.uol.com.br/fsp/cotidian /ff0312200010.htm.> Acessado em: 26 nov. 2010.

Penin, Sonia. Repetência escolar: há ganhos? Folha de São Paulo. Opinião. 06 abr. 2000. Disponível em: <http://www1.folha.uol.com.br/fsp/opiniao/fz0604200010.htm.> Acessado em: 26 nov. 2010.

PENTEAdO, Gilmar. Estudo da USP avalia violência em escolas. Folha de São Paulo. Cotidiano. 23 nov. 2002. Disponível em: <http://www1.folha.uol.com.br/fsp/cotidian/ ff2311200213.htm.> Acessado em: 26 nov. 2010.

PEREIRA Filho, Armando. Em São Paulo, novo secretário prioriza a segurança. Folha de São Paulo. Cotidiano. 14 abr. 2002. Disponível em: <http://www1.folha.uol.com.br/fsp/ cotidian/ff1404200205.htm.> Acessado em: 24/10/10.

PEREIRA FiLho, Armando. Escola ensina pais a organizar lição de casa. Folha de São Paulo. Cotidiano. 17 mar. 2003. Disponível em: <http://www1.folha.uol.com.br/fsp/ cotidian/ff1703200315.htm.> Acessado em: 26 nov. 2010.

PereIRA FILHO, Armando. Para especialistas, escola deve ensinar tolerância. Folha de São Paulo. Cotidiano. 20 fev. 2003. Disponível em: <http://www1.folha.uol.com.br/fsp/ cotidian/ff2002200311.htm.> Acessado em: 26 nov. 2010.

PEREIRA FILHO, Armando. Recuperação exige que aluno saiba estudar. Folha de São Paulo. Cotidiano. 08 dez. 2002. Disponível em: <http://www1.folha.uol.com.br/fsp/ cotidian/ff0812200208.htm.> Acessado em: 26 nov. 2010.

PEREIRA FILHO. Armando. Projeto contra analfabetismo não decola. Folha de São Paulo. Cotidiano. 13 abr. 2003. Disponível em: <http://www1.folha.uol.com.br/fsp/ cotidian/ff1304200318.htm.> Acessado em: 26 nov. 2010.

PEREZ, Maria Aparecida. Escola é aluno, professor e comunidade. Folha de São Paulo. Opinião. 29 ago. 2003. Disponível em: <http://www1.folha.uol.com.br/fsp/opiniao/ fz2908200309.htm.> Acessado em: 26 nov. 2010.

Portella, Eduardo. Educação na fila de espera. Folha de São Paulo. Opinião. 16 ago. 2004. Disponível em: <http://www1.folha.uol.com.br/fsp/opiniao/fz1608200409.htm.> Acessado em: 26 nov. 2010.

QUALIFICAR o professor. Folha de São Paulo. Editorial. 02 ago. 2003. Disponível em: <http://www1.folha.uol.com.br/fsp/opiniao/fz2211200303.htm.> Acessado em: 26 nov. 2010 .

Rattner, Henrique. A escola que queremos. Folha de São Paulo. Cotidiano. 01 dez. 1997. Disponível em: <http://www1.folha.uol.com.br/fsp/cotidian/ff011206.htm.> Acessado em: 26 nov. 2010.

RAW, Isaias. Retrocesso na educação. Folha de São Paulo. Opinião. 20 out. 1998. Disponível em: <http://www1.folha.uol.com.br/fsp/opiniao/fz20109810.htm.> Acessado em: 26 nov. 2010 
RAW, Isaias. Todos na escola ou escola para todos. Folha de São Paulo. Opinião. 6 out. 1997. Disponível em: <http://www1.folha.uol.com.br/fsp/1997/10/06/opiniao/9.html.> Acessado em: 26 nov. 2010.

Reforma no segundo grau. Folha de São Paulo. Editorial. 06 jun. 1997. Disponível em: <http://www1.folha.uol.com.br/fsp/opiniao/fz060701.htm.> Acessada em 24/10/10.

RENDA e educação. Folha de São Paulo. Editorial. 02 ago. 2004. Disponível em: <http://www1.folha.uol.com.br/fsp/opiniao/fz0208200402.htm.> Acessado em: 26 nov. 2010 .

RENDA e instrução mínimas. Folha de São Paulo. Editorial. 16 dez. 1999. Disponível em: <http://www1.folha.uol.com.br/fsp/opiniao/fz1612199901.htm.> Acessado em: 26 nov. 2010.

RIBEIRo, Denise. O quadro se agrava. Folha de São Paulo. Sinapse. 27 set. 2005. Disponível em: <http://www1.folha.uol.com.br/fsp/sinapse/sa2709200507.htm.> Acessado em: 13 abr. 2010.

Rigout, Fabrizio. Métodos pedagógicos diversos se cruzam no ensino privado. Folha de São Paulo. Caderno Especial. 07 ago. 1997. Disponível em: <http://www1.folha.uol.com.br/fsp/ especial/fj070802.htm.> Acessado em: 26 nov. 2010.

RIGOUT, Fabrizio. Quando pais participam, rede pública tem bom desempenho. Folha de São Paulo. Caderno Especial. 07 ago. 1997. Disponível em: <http://www1.folha.uol.com.br/fsp/especial/fj070802.htm.> Acessado em: 13 abr. 2010.

Rondon, José Eduardo. Aluno ganha brinde para não deixar escola. Folha de São Paulo. Cotidiano. 06 fev. 2005. Disponível em: <http://www1.folha.uol.com.br/fsp/ cotidian/ff0602200515.htm.> Acessado em: 26 nov. 2010.

RosSETTI, Fernando. 1996 foi o ano da mudança na legislação. Folha de São Paulo. Cotidiano. 30 dez. 1996. Disponível em: <http://www1.folha.uol.com.br/fsp/1996/ 12/30/cotidiano/4.html.> Acessado em: 26 nov. 2010.

RossetTi, Fernando. 56\% das escolas do país sofrem violência. Folha de São Paulo. Cotidiano. 19 abr. 1998. Disponível em: <http://www1.folha.uol.com.br/fsp/ cotidian/ff19049801.htm.> Acessado em: 26 nov. 2010.

Rossetti, Fernando. Autonomia melhora as escolas de Minas. Folha de São Paulo. Cotidiano. 19 jan. 1997. Disponível em: <http://www1.folha.uol.com.br/fsp/1997/1/19/ cotidiano/25.html.> Acessado em: 26 nov. 2010.

RossetTI, Fernando. Cidades pequenas têm melhores escolas. Folha de São Paulo. Cotidiano. 27 jun. 1998. Disponível em: <http://www1.folha.uol.com.br/fsp/cotidian /ff27069801.htm.> Acessado em: 26 nov. 2010.

RosSETTI, Fernando. Diretores divergem sobre o que as crianças precisam aprender hoje. Folha de São Paulo. Caderno Especial. 07 ago. 1997. Disponível em: <http://www1.folha.uol.com.br/fsp/especial/fj070809.htm.> Acessado em: 26 nov. 2010 .

RosSETTI, Fernando. Educador quer creche 'igual' a pré-escola. 23 set. 1997. Folha de São Paulo. Cotidiano. Disponível em: <http://www1.folha.uol.com.br/fsp/1997/9/23/ cotidiano/32.html.> Acessado em: 13 abr. 2010. 
RossetTI, Fernando. Escola fechada impossibilita matrícula. Folha de São Paulo. Cotidiano. 27 dez. 1996. Disponível em: <http://www1.folha.uol.com.br/fsp/1996/ 12/27/cotidiano/ 17.html.> Acessado em: 26 nov. 2010.

RossetTi, Fernando. Escola pública cobra taxas. Folha de São Paulo. Cotidiano. 19 jan. 1997. Disponível em:<http://www1.folha.uol.com.br/fsp/1997/1/19/cotidiano/26.html.> Acessado em: 26 nov. 2010.

Rossetti, Fernando. Federação da indústria combate reprovação. Folha de São Paulo. Cotidiano. 19 jan. 1997. Disponível em: <http://www1.folha.uol.com.br/fsp/1997/1/ 19/cotidiano/ 28.html.> Acessado em: 26 nov. 2010.

RossetTI, Fernando. Fim da repetência cria 'lei de Gérson'. Folha de São Paulo. Cotidiano. 18 set. 1997. Disponível em: <http://www1.folha.uol.com.br/fsp/cotidian/ ff180916.htm.> Acessado em: 26 nov. 2010.

RossetTI, Fernando. Formação de docente explica nota baixa. Folha de São Paulo. Cotidiano. 10 jun. 1998. Disponível em: <http://www1.folha.uol.com.br/fsp/cotidian/ff 10069819.htm.> Acessado em: 13 abr. 2010.

Rossetti, Fernando. Heterogeneidade dos alunos muda currículo. Folha de São Paulo. Cotidiano. 16 jun. 1998. Disponível em: <http://www1.folha.uol.com.br/fsp/cotidian/ ff16069804.htm.> Acessado em: 26 nov. 2010.

Rossetti, Fernando. Pré-escola cresce à custa da qualidade do atendimento. Folha de São Paulo. Cotidiano. 04 fev. 1998. Disponível em: <http://www1.folha.uol.com.br/fsp/ cotidian/ ff04029844.htm.> Acessado em: 26 nov. 2010.

RossetTi, Fernando. Pré-escola socializa a criança e melhora desempenho futuro. Folha de São Paulo. Cotidiano. 04 fev. 1998. Disponível em: <http://www1.folha.uol.com.br/ fsp/cotidian/ff04029841.htm.> Acessado em: 26 nov. 2010.

RossetTI, Fernando. 'Professor de matemática não aprendeu a ensinar'. Folha de São Paulo. Cotidiano. 17 set. 1998. Disponível em: <http://www1.folha.uol.com.br /fsp/cotidian/ff17099810.htm.> Acessado em: 26 nov. 2010.

RossetTI, Fernando. Professores criticam recuperação em SP. Folha de São Paulo. Cotidiano. 12 dez. 1997. Disponível em: <http://www1.folha.uol.com.br/fsp/ cotidian/ff121239.htm.> Acessado em: 26 nov. 2010.

RossetTI, Fernando. Qual a escolha ideal para sua criança. Folha de São Paulo. Caderno Especial. 07 ago. 1997. Disponível em: <http://www1.folha.uol.com.br/fsp/ especial/fj070801.htm.> Acessado em: 26 nov. 2010.

Rossi, Clovis. Devolvam a "minha" escola. Folha de São Paulo. Opinião. 16 fev. 2006. Disponível em: <http://www1.folha.uol.com.br/fsp/opiniao/fz1602200604.htm.> Acessado em: 26 nov. 2010.

RuIZ, Silvia. Por que estes estudantes são barrados na escola. Folha de São Paulo. Folhateen. 12 jul. 1999. Disponível em: <http://www1.folha.uol.com.br/fsp/folhatee/fm 12079901.htm.> Acessado em: 26 nov. 2010.

Salomon, Marta. Reforma elimina 'enciclopedismo' dos currículos. Folha de São Paulo. Cotidiano. 9 fev. 1998. Disponível em: <http://www1.folha.uol.com.br/fsp/ cotidian/ff09029820. htm.> Acessado em: 26 nov. 2010. 
SANTIAGO, Vandeck . Educação é saída para estudantes pobres. Folha de São Paulo. Cotidiano. 25 jan. 1997. Disponível em: <http://www1.folha.uol.com.br/fsp/1997/1/25/ cotidiano/30.html.> Acessado em: 26 nov. 2010.

SAntos, Chico. Estudar virou prioridade entre os mais jovens. Folha de São Paulo. Dinheiro. 13 jan. 2002. Disponível em: <http://www1.folha.uol.com.br/fsp/dinheiro/fi 1301200203.htm.> Acessado em: 26 nov. 2010.

Schivartche, Fábio. Escolas têm monitoramento on-line. Folha de São Paulo. Cotidiano. 07 set. 2005. Disponível em: <http://www1.folha.uol.com.br/fsp/cotidian/ff0 709200516.htm.> Acessado em: 26 nov. 2010.

Schivartche, Fábio. Rede estadual adota 'dependência' em 97. Folha de São Paulo. Cotidiano. 21 dez. 1996. Disponível em: <http://www1.folha.uol.com.br/fsp/1996/12/21 /cotidiano/32.html.> Acessado em: 26 nov. 2010.

SEMEAndo educação. Folha de São Paulo. Editorial. 19 jan. 1997. Disponível em: <http://www1.folha.uol.com.br/fsp/1997/1/19/opiniao/2.html.> Acessado em: 26 nov. 2010 .

SERrA, José. A revolução do Verbo. A revolução do Verbo. Folha de São Paulo. Opinião. 05 mar. 2006. Disponível em: <http://www1.folha.uol.com.br/fsp/ opiniao/fz0503200608.htm.> Acessado em: 26 nov. 2010.

Setubal, Maria Alice. Ensino médio e cidadania. Folha de São Paulo. Opinião. 04 fev. 1999. Disponível em: <http://www1.folha.uol.com.br/fsp/cotidian/ff04029909.htm.> Acessado em: 26 nov. 2010.

Setubal, Maria Alice. Saída para fracasso escolar. Folha de São Paulo. Opinião. 14 jul. 1997. Disponível em: <http://www1.folha.uol.com.br/fsp/cotidian/ff140708.htm.> Acessado em: 13 abr. 2010.

SEXo, ética e ensino básico. Folha de São Paulo. Editorial. 11 jan. 1998. Disponível em: <http://www1.folha.uol.com.br/fsp/opiniao/fz110102.htm.> Acessado em: 26 nov. 2010

Schwartsman, Hélio. A vingança da decoreba. Folha de São Paulo. Opinião. 22 jan. 2011. Disponível em: <http://www1.folha.uol.com.br/fsp/opiniao/fz2201201103.htm.> Acessado em: 23 jan. 2011.

Silva, Adriana Souza. Desempenho de estudante é afetado por vida familiar. Folha de São Paulo. Cotidiano. 20 dez. 1999. Disponível em: <http://www1.folha.uol.com.br/fsp/ cotidian/ff2012199906.htm.> Acessado em: 26 nov. 2010

SiLva, Alessandro. Rede estadual vai ampliar avaliação. Folha de São Paulo. Cotidiano. 30 out. 2002. Disponível em: <http://www1.folha.uol.com.br/fsp/cotidian /ff3010200213.htm.> Acessado em: 26 nov. 2010.

SILVA, Edevaldo Alves da. Educação e qualidade. Folha de São Paulo. Opinião. 15 set. 2003. Disponível em: 〈http://www1.folha.uol.com.br/fsp/opiniao/fz1509200310.htm.> Acessado em: 26 nov. 2010.

SILva, João Carlos. Consumo de drogas atinge 32\% das escolas. Folha de São Paulo. Cotidiano. 10 mai. 2002. Disponível em: <http://www1.folha.uol.com.br/fsp/cotidian /ff1005200220.htm.> Acessado em: 26 nov. 2010. 
Silva, João Carlos. Rede municipal de ensino terá apoio francês. Folha de São Paulo. Cotidiano. 01 mar 2001. Disponível em: <http://www1.folha.uol.com.br/fsp/ cotidian/ff0103200115.htm.> Acessado em: 26 nov. 2010.

Silva. João Carlos. Rede municipal de ensino terá apoio francês. Folha de São Paulo. Cotidiano. 01 mar. 2001. Disponível em: <http://www1.folha.uol.com.br/fsp/cotidian/ ff0103200115.htm.> Acessado em: 26 nov. 2010.

Simionato, Maurício. Professora é acusada de calar aluno com fita crepe. Folha de São Paulo. Cotidiano. 07 dez. 2004. Disponível em: <http://www1.folha.uol.com.br/fsp/ opiniao/fz1612200410.htm.> Acessado em: 26 nov. 2010.

Simionato, Maurício. Docente diz que punição a criança foi "brincadeira". Folha de São Paulo. Cotidiano. 07 dez. 2004. Disponível em: <http://www1.folha.uol.com.br/fsp/ cotidian/ff0712200420.htm.> Acessado em: 26 nov. 2010.

SiqueIRA, Fausto. Escolas de Santos têm 1.493 analfabetos. Folha de São Paulo. Cotidiano. 30 mai. 2002. Disponível em: <http://www1.folha.uol.com.br/fsp/cotidian /ff3005200202.htm.> Acessado em: 26 nov. 2010.

SiQueIRA, Fausto. SP tem 2.000 escolas sem câmeras. Folha de São Paulo. Cotidiano. 04 jun. 2002. Disponível em: <http://www1.folha.uol.com.br/fsp/cotidian/ff040620 0207.htm.> Acessado em: 26 nov. 2010.

SOARES, Ismar de Oliveira. A comunicação e o ensino médio. Folha de São Paulo. Opinião. 21 dez. 1998. Disponível em: <http://www1.folha.uol.com.br/fsp/cotidian /ff21129808.htm.> Acessado em: 26 nov. 2010. Acessado em: 26 nov. 2010.

SoARES, Pedro. Alunos da rede pública têm aulas mais curtas. Folha de São Paulo. Cotidiano. 23 mar. 2006. Disponível em: <http://www1.folha.uol.com.br/fsp/brasil/ fc2303200623.htm.> Acessado em: 26 nov. 2010.

SoAres, Wander. Nozes para desdentados. Folha de São Paulo. Cotidiano. 30 dez. 1996. Disponível em: <http://www1.folha.uol.com.br/fsp/1996/12/30/cotidiano/7.html.>

SoARES, Wander. Quem não lê não escreve. Folha de São Paulo. Opinião. 24 fev. 1997. Disponível em: <http://www1.folha.uol.com.br/fsp/1997/2/24/opiniao/9.html.> Acessado em: 26 nov. 2010.

SoRDILI, Aline. Instituto investe para eliminar a repetência escolar em 15 cidades. Folha de São Paulo. Caderno especial. 19 dez. 1997. Disponível em: <http://www1.folha.uol. com.br/fsp/especial/fj191223.htm.> Acessado em: 26 nov. 2010.

SouzA, Paulo Renato. Conquistas e desafios da educação. Folha de São Paulo. Opinião. 15 abr. 2001. Disponível em: <http://www1.folha.uol.com.br/fsp/opiniao/fz15042 00109.htm.> Acessado em: 26 nov. 2010.

SouZA, Paulo Renato. Mais igualdade na educação. Folha de São Paulo. Opinião. 06 out. 1999. Disponível em: <http://www1.folha.uol.com.br/fsp/opiniao/fz061019990 9.htm.> Acessado em: 26 nov. 2010.

StACHUK, Mayra. Estado amplia avaliação de alunos. Folha de São Paulo. Cotidiano. 06 out. 2004. Disponível em: <http://www1.folha.uol.com.br/fsp/cotidian/ff0610200411 .htm.> Acessado em: 26 nov. 2010. 
Steinbruch, Benjamin. Cultivar a educação. Folha de São Paulo. Dinheiro. 11 mar. 2003. Disponível em:<http://www1.folha.uol.com.br/fsp/dinheiro/fi1103200306.htm.> Acessado em: 26 nov. 2010.

Steinbruch, Benjamin. Ouviram do Ipiranga... Folha de São Paulo. Dinheiro. 05 mar. 2002. Disponível em:<http://www1.folha.uol.com.br/fsp/dinheiro/fi0503200202.htm.> Acessado em: 26 nov. 2010.

Strauss, Luis Renato. Aluno acelera troca da escola por trabalho. Folha de São Paulo. Cotidiano. 07 out. 2004. Disponível em: <http://www1.folha.uol.com.br/fsp/cotidian/ ff0710200413.htm.> Acessado em: 26 nov. 2010.

Strauss, Luis Renato. Para pais escola publica é "terra de ninguém". Folha de São Paulo. Cotidiano. 20 jan. 2005. Disponível em: <http://www1.folha.uol.com.br/fsp/ cotidian/ ff2001200524. htm.> Acessado em: 13 abr. 2010.

Suwwan, Leila. Aluno brasileiro é mal avaliado em pesquisa. Folha de São Paulo. Cotidiano. 05 dez. 2001. Disponível em: <http://www1.folha.uol.com.br/fsp/cotidian/ ff0512200123.htm.> Acessado em: 26 nov. 2010.

Suwwan, Leila. Aluno de 10 anos receberá educação sexual, afirma nova política federal. Folha de São Paulo. Cotidiano. 16 mar. 2005. Disponível em: <http:// www1.folha.uol.com.br/fsp/ cotidian/ff1603200501.htm.> Acessado em: 26 nov. 2010.

Suwwan, Leila. Brasil é o último em prova de matemática. Folha de São Paulo. Cotidiano. 08 dez. 2001. Disponível em: <http://www1.folha.uol.com.br/fsp/cotidian/ff 0812200121.htm.> Acessado em: 26 nov. 2010.

Suwwan, Leila. Como a epidemia de violência invade até as escolas? Folha de São Paulo. Folhateen. 01 abr. 2002. Disponível em: <http://www1.folha.uol.com.br/fsp/ folhatee/fm0104200226.htm.> Acessado em: 26 nov. 2010.

Suwwan, Leila. Cresce repetência no ensino fundamental. Folha de São Paulo. Cotidiano. 24 mai. 2002. Disponível em: <http://www1.folha.uol.com.br/fsp/cotidia n/ff2405200224.htm.> Acessado em: 26 nov. 2010.

SUWWAN, Leila. Governo distribui kit para combater racismo em escola. Folha de São Paulo. Cotidiano. 02 out. 2004. Disponível em: <http://www1.folha.uol.com.br/fsp/ brasil/ fc0210200408.htm.> Acessado em: 26 nov. 2010.

Suwwan, Leila. Pesquisa quantifica crimes nas escolas. Folha de São Paulo. Cotidiano. 26 mar. 2002. Disponível em: <http://www1.folha.uol.com.br/fsp/cotidian/ff2603 200217.htm.> Acessado em: 26 nov. 2010.

TAKAHASHI, Fabio. 11,5\% das crianças de seis anos do país estão fora da sala de aula. Folha de São Paulo. Cotidiano. 07 fev. 2006. Disponível em: <http://www1.folha.uol. com.br/fsp/cotidian/ff0702200613.htm.> Acessado em: 13 abr. 2010.

TAKAHASHI, Fabio. 170 colégios estaduais terão período integral. Folha de São Paulo. Cotidiano. 09 dez. 2005. Disponível em: <http://www1.folha.uol.com.br/fsp/cotidian/ff 0912200513.htm.> Acessado em: 26 nov. 2010.

TAKAHASHI, Fábio. Aluno da rede pública tem avaliação melhor. Folha de São Paulo. Cotidiano. 29 mar. 2004. Disponível em: <http://www1.folha.uol.com.br/fsp/cotidian/ ff2903200421.htm.> Acessado em: 26 nov. 2010. 
TAKAHASHI, Fábio. Avaliações são quase inócuas, diz especialista. Folha de São Paulo. Cotidiano. 05.dez. 2005. Disponível em:<http://www1.folha.uol.com.br/fsp/cotidian/ ff0512200519.htm.> Acessado em: 26 nov. 2010.

TAKAHASHI, Fábio. Cai o número de aprovados no ensino médio em São Paulo. Folha de São Paulo. Cotidiano. 01 ago. 2006. Disponível em: <http://www1.folha.uol. com.br/fsp/cotidian /ff0108200610.htm.> Acessado em: 26 nov. 2010.

TAKAHASHI, Fábio. Escola estadual com 3 turnos terá aula aos sábados em SP. Folha de São Paulo. Cotidiano. 02 set. 2006. Disponível em: <http://www1.folha.uol.com.br/fsp/ cotidian/ff0209200614.htm.> Acessado em: 26 nov. 2010.

TAKAHASHI, Fabio. Escolas "treinam" emoções de crianças. Folha de São Paulo. Cotidiano. 04 out. 2005. Disponível em: <http://www1.folha.uol.com.br/fsp/ cotidian/ff1610200506.htm.> Acessado em: 26 nov. 2010.

TAKAHASHI, Fabio. Escolas barram lancheira "trash" no recreio. Folha de São Paulo. Cotidiano. 24 abr. 2005. Disponível em: <http://www1.folha.uol.com.br/fsp/cotidian /ff2404200507.htm.> Acessado em: 26 nov. 2010.

TAKAHASHI, Fábio. Investir em estrutura não basta, dizem educadores. Folha de São Paulo. Cotidiano. 28 set. 2006. Disponível em: <http.://www1.folha.uol.com.br/fsp/ cotidian/ff2809200607.htm.> Acessado em: 26 nov. 2010.

TAKAHASHI, Fábio. Metade dos docentes já foi xingada por aluno. Folha de São Paulo. Cotidiano. 01 mai. 2006. Disponível em: <http://www1.folha.uol.com.br/fsp/cotidian/ ff0105200601.htm.> Acessado em: 26 nov. 2010.

TAKAHASHI, Fabio. Pais socorrem escolas técnicas de Alckmin. Folha de São Paulo. Cotidiano. 03 nov. 2005. Disponível em: <http://www1.folha.uol.com.br/fsp/cotidian /ff0311200501.htm.> Acessado em: 26 nov. 2010.

TAKAHASHI, Fábio. País tem repetência maior que a do Camboja. Folha de São Paulo. Cotidiano. 26 abr. 2006. Disponível em: <http://www1.folha.uol.com.br/fsp/cotidian/ ff2604200601.htm.> Acessado em: 26 nov. 2010.

TAKAHASHI, Fábio. Pesquisadores divergem sobre ensino fundamental de 9 anos. Folha de São Paulo. Cotidiano. 17 out. 2006. Disponível em: <http://www1.folha.uol.com.br /fsp/cotidian/ ff1710200615.htm.> Acessado em: 26 nov. 2010.

TAKAHASHI, Fabio. Portaria autoriza professor a medicar aluno. Folha de São Paulo. Cotidiano. 11 mai. 2005. Disponível em: <http://www1.folha.uol.com.br/fsp/cotidian/ ff1105200541.htm.> Acessado em: 26 nov. 2010.

TAKAhashi, Fabio. Projetos descontínuos afetam qualidade do ensino. Folha de São Paulo. Cotidiano. 04 set. 2005. Disponível em: <http://www1.folha.uol.com.br/fsp/ cotidian/ff0409200526.htm.> Acessado em: 26 nov. 2010.

TARDÁGUILA, Cristina. Segundo professores, piadinha inocente esconde preconceito. Folha de São Paulo. Cotidiano. 25 jul. 2006. Disponível em: <http://www1.folha.uol. com.br/fsp/cotidian/ ff2507200616.htm.> Acessado em: 26 nov. 2010.

TAVARES, Ingrid. Espaço e faixa etária da criança têm de dialogar. Folha de São Paulo. Cotidiano. 24 set. 2006. Disponível em: <http://www1.folha.uol.com.br/fsp/cotidian/ ff2409200629.htm.> Acessado em: 26 nov. 2010. 
TEMPO integral. Folha de São Paulo. Editorial. 13 dez. 2005. Disponível em: <http://www1.folha.uol.com.br/fsp/opiniao/fz1312200503.htm.> Acessado em: 13 abr. 2010 .

Terceiros na educação. Folha de São Paulo. Editorial. 06 fev. 2006. Disponível em: <http://www1.folha.uol.com.br/fsp/opiniao/fz0602200602.htm.> Acessado em: 26 nov. 2010 .

Tófoli, Daniela. Alunos de escola de lata e de CEU têm desempenho igual. Folha de São Paulo. Cotidiano. 28 set. 2006. Disponível em: <http://www1.folha.uol.com.br/fsp/ cotidian/ ff2809200601.htm.> Acessado em: 26 nov. 2010.

Tófoli, Daniela. Diretores de escola receberão treinamento. Folha de São Paulo. Cotidiano. 21 fev. 2006. Disponível em: <http://www1.folha.uol.com.br/fsp/cotidian/ ff2102200621.htm.> Acessado em: 26 nov. 2010.

TóFoli, Daniela. Escola municipal terá carga horária maior. Folha de São Paulo. Cotidiano. 14 ago. 2006. Disponível em: <http://www1.folha.uol.com.br/fsp/ cotidian/ff1408200617.htm.> Acessado em: 26 nov. 2010.

Tófoli, Daniela. Escolas ainda promovem "vestibulinho". Folha de São Paulo. Cotidiano. 24 out. 2006. Disponível em: <http://www1.folha.uol.com.br/fsp/cotidian /ff2410200616.htm.> Acessado em: 26 nov. 2010.

Tófoli, Daniela. Escolas municipais terão apoio médico. Folha de São Paulo. Cotidiano. 13 nov. 2005. Disponível em: <http://www1.folha.uol.com.br/fsp/cotidian/ ff1311200509.htm.> Acessado em: 26 nov. 2010.

Tófoli, Daniela. Juiz decide que escola privada pode vetar criança com Down. Folha de São Paulo. Cotidiano. 17 out. 2006. Disponível em: <http://www1.folha.uol.com.br /fsp/cotidian /ff1710200616.htm.> Acessado em: 26 nov. 2010.

TóFoli, Daniela. Prefeituras de SP terceirizam a educação. Folha de São Paulo. Cotidiano. 30 jan. 2006. Disponível em: <http://www1.folha.uol.com.br/fsp/cotidian /ff3001200601.htm.> Acessado em: 26 nov. 2010.

Últimos da classe. Folha de São Paulo. Editorial. 08 dez. 2004. Disponível em: <http://www1.folha.uol.com.br/fsp/opiniao/fz0812200401.htm.> Acessado em: 24/10/10.

Unger, Roberto Mangabeira. A prioridade de São Paulo. Folha de São Paulo. Opinião. 25 abr. 2000. Disponível em: <http://www1.folha.uol.com.br/fsp/opiniao/fz25042 00009.htm.> Acessado em: 26 nov. 2010.

Unger, Roberto Mangabeira. Educação para valer. Folha de São Paulo. Opinião. 14 nov. 2006. Disponível em: <http://www1.folha.uol.com.br/fsp/opiniao/fz141120 0606.htm.> Acessado em: 26 nov. 2010.

Unger, Roberto Mangabeira. Educação sem romantismo. Folha de São Paulo. Opinião. 03 out. 2006. Disponível em: <http://www1.folha.uol.com.br/fsp/opiniao/fz031020 0606.htm.> Acessado em: 26 nov. 2010.

Unger, Roberto Mangabeira. Ensino já. Folha de São Paulo. Opinião. 18 mar. 2003. Disponível em: <http://www1.folha.uol.com.br/fsp/opiniao/fz1803200307.htm.> Acessado em: 26 nov. 2010. 
Unger, Roberto Mangabeira. Revolucionar o ensino público. Folha de São Paulo. Opinião. 04 out. 2005. Disponível em: <http://www1.folha.uol.com.br/fsp/opiniao/fz0 410200507.htm.> Acessado em: 26 nov. 2010.

Unger, Roberto Mangabeira. Virada na educação. Folha de São Paulo. Opinião. 15 ago. 2006. Disponível em: <http://www1.folha.uol.com.br/fsp/opiniao/fz150820 0606.htm.> Acessado em: 26 nov. 2010.

VAlente, Ivan.. Educação de qualidade. Folha de São Paulo Opinião. 07 mai. 1998. Disponível em:<http://www1.folha.uol.com.br/fsp/opiniao/fz07059809.htm.> Acessado em: $28 / 11 / 10$.

VAZ, Marcelo. As notas baixas do Enem. Folha de São Paulo. Folhateen. 18 nov. 2002. Disponível em: <http://www1.folha.uol.com.br/fsp/folhatee/fm1811200223.htm.> Acessado em: 26 nov. 2010.

VERSIANI, Isabel. Sistema fiscal é ensinado nas escolas. Folha de São Paulo. Cotidiano. 04 fev. 1998. Disponível em: <http://www1.folha.uol.com.br/fsp/cotidian/ff04029840 .htm.> Acessado em: 26 nov. 2010.

Villela, Milú. A educação e o PIB. Folha de São Paulo. Opinião. 16 dez. 2004. Disponível em: <http://www1.folha.uol.com.br/fsp/cotidian/ff2612200412.htm.> Acessado em: 26 nov. 2010.

VILlELA, Milú. Solidariedade também se aprende na escola. Folha de São Paulo. Opinião. 14 jun. 2005a. Disponível em: <http://www1.folha.uol.com.br/fsp/opiniao/fz14 06200509.htm.> Acessado em: 26 nov. 2010

VILlElA, Milú. Educação, instrumento contra desigualdade. Folha de São Paulo. Opinião. 15 set. 2005b. Disponível em: <http://www1.folha.uol.com.br/fsp/opiniao /fz1509200509.htm.> Acessado em: 26 nov. 2010.

VILlela, Milú. O remédio necessário. Folha de São Paulo. Opinião. 04 mai. 2006b. Disponível em: <http://www1.folha.uol.com.br/fsp/opiniao/fz0405200610.htm.> Acessado em: 24/10/10.

VILlelA, Milú. Receita para 2006. Folha de São Paulo. Opinião. 19 jan. 2006a. Disponível em: <http://www1.folha.uol.com.br/fsp/opiniao/fz1901200610.htm.> Acessado em: 13 abr. 2010.

WERNECK, Guilherme. Colégios tentam o diálogo, mas não para casos graves. Folha de São Paulo. Folhateen. 10 dez. 2001. Disponível em: <http://www1.folha.uol.com.br/fsp/ folhatee/fm1012200113.htm.> Acessado em: 26 nov. 2010.

Werthein, Jorge. A relevância da educação infantil. Folha de São Paulo. Opinião. 12 out. 2001. Disponível em: <http://www1.folha.uol.com.br/fsp/opiniao/fz12102001 09.htm.> Acessado em: 26 nov. 2010.

Werthein, Jorge. Educação de adultos e democracia. Folha de São Paulo. Opinião. 07 jun. 1998. Disponível em: <http://www1.folha.uol.com.br/fsp/opiniao/fz07069808.ht m.> Acessado em: 24/10/10.

Werthein, Jorge. Educação intermitente. Folha de São Paulo. Opinião. 03 out. 1999. Disponível em: <http://www1.folha.uol.com.br/fsp/opiniao/fz0310199909.htm.> Acessado em: 26 nov. 2010. 
Werthein, Jorge. Juventude, educação e cidadania. Folha de São Paulo. Opinião. 14 mar. 2006. Disponível em: <http://www1.folha.uol.com.br/fsp/opiniao/fz1403200609. htm.> Acessado em: 26 nov. 2010.

Werthein, Jorge. Por uma escola de paz. Folha de São Paulo. Opinião. 16 set. 2004. Disponível em: <http://www1.folha.uol.com.br/fsp/opiniao/fz1609200410.htm.> Acessado em: 26 nov. 2010.

YURI, Débora. Colar ficou mais fácil com as novas tecnologias. Folha de São Paulo. Cotidiano. 16 mai. 2004. Disponível em: <http://www1.folha.uol.com.br/fsp/cotidian/ ff1605200434.htm.> Acessado em: 26 nov. 2010.

YURI, Débora. Periferia de SP vive o cotidiano da violência na educação. Folha de São Paulo. Cotidiano. 24 jun. 2001. Disponível em: <http://www1.folha.uol.com.br/fsp /cotidian/ ff2406200127.htm.> Acessado em: 26 nov. 2010.

YuRI, Débora. Pesquisa derruba "achismos" sobre escola. Folha de São Paulo. Cotidiano. 28 set. 2003. Disponível em: <http://www1.folha.uol.com.br/fsp/ cotidian/ff2809200320.htm.> Acessado em: 26 nov. 2010.

ZanchetTA, Diego. Alunos depredam escola estadual em Guarulhos. Folha de São Paulo. Cotidiano. 30 ago. 2006. Disponível em: <http://www1.folha.uol.com.br/fsp/ cotidian/ff3008200621.htm.> Acessado em: 26 nov. 2010.

ZAnChETTA, Diego. Sem professor, escola faz rodízio de alunos. Folha de São Paulo. Cotidiano. 14 abr. 2006. Disponível em: <http://www1.folha.uol.com.br/fsp/cotidian/ ff1404200616.htm.> Acessado em: 26 nov. 2010.

ZILVETI, Marijô. Internet vira extensão da sala de aula. Folha de São Paulo. Informática. 06 fev. 2002. Disponível em: <http://www1.folha.uol.com.br/fsp/informat/ fr0602200201.htm.> Acessado em: 26 nov. 2010. 